\title{
Materials and Security Consolidation Complex Facilities Radioactive Waste Management Basis and DOE Manual 435.1-1 Compliance Tables
}

September 2011

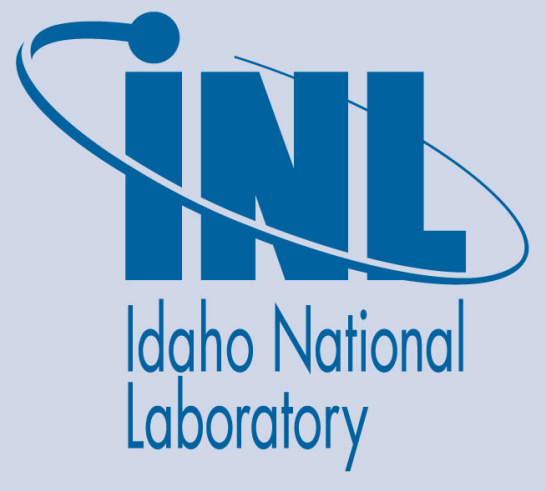

The INL is a U.S. Department of Energy National Laboratory operated by Battelle Energy Alliance 


\section{DISCLAIMER}

This information was prepared as an account of work sponsored by an agency of the U.S. Government. Neither the U.S. Government nor any agency thereof, nor any of their employees, makes any warranty, expressed or implied, or assumes any legal liability or responsibility for the accuracy, completeness, or usefulness, of any information, apparatus, product, or process disclosed, or represents that its use would not infringe privately owned rights. References herein to any specific commercial product, process, or service by trade name, trade mark, manufacturer, or otherwise, does not necessarily constitute or imply its endorsement, recommendation, or favoring by the U.S. Government or any agency thereof. The views and opinions of authors expressed herein do not necessarily state or reflect those of the U.S. Government or any agency thereof. 


\section{Materials and Security Consolidation Complex Facilities Radioactive Waste Management Basis and DOE Manual 435.1-1 Compliance Tables}

September 2011

Idaho National Laboratory Idaho Falls, Idaho 83415

http://www.inl.gov

Prepared for the

U.S. Department of Energy

Office of Nuclear Energy

Under DOE Idaho Operations Office

Contract DE-AC07-05ID14517 



\begin{abstract}
Department of Energy Order 435.1, "Radioactive Waste Management," along with its associated manual and guidance, requires development and maintenance of a radioactive waste management basis for each radioactive waste management facility, operation, and activity. This document presents a radioactive waste management basis for Idaho National Laboratory's Materials and Security Consolidation Complex facilities that manage radioactive waste. The radioactive waste management basis for a facility comprises existing laboratory-wide and facility-specific documents. Department of Energy Manual 435.1-1, "Radioactive Waste Management Manual," facility compliance tables also are presented for the facilities. The tables serve as a tool for developing the radioactive waste management basis.
\end{abstract}




\section{CONTENTS}

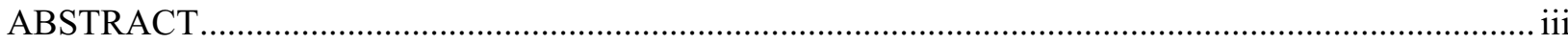

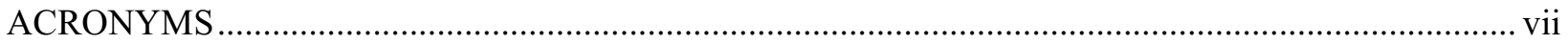

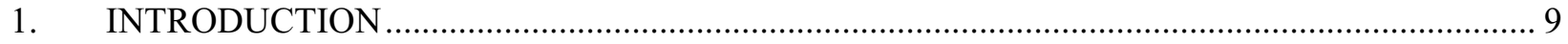

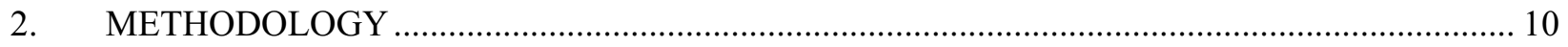

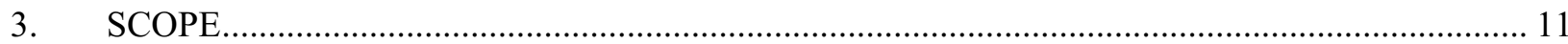

4. FACILITY RADIOACTIVE WASTE MANAGEMENT BASIS AND

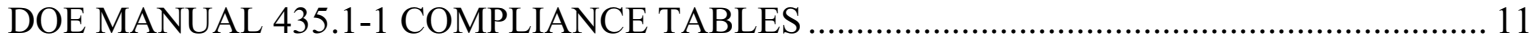

4.1 CPP-651, Materials and Security Consolidation Facility ................................................ 11

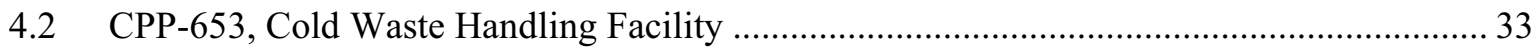

4.3 CPP-1634, Technology Development Facility .............................................................. 53

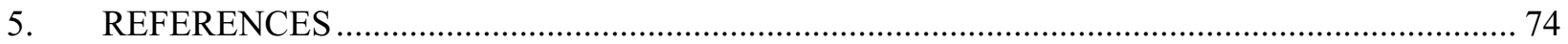

\section{TABLES}

1. CPP-651, Materials and Security Consolidation Facility, DOE Manual 435.1-1 low-level waste requirements and facility compliance information

2. CPP-653, Cold Waste Handling Facility, DOE Manual 435.1-1 low-level waste requirements and facility compliance information

3. CPP-1634, Technology Development Facility, DOE Manual 435.1-1 low-level waste requirements and facility compliance information 


\section{ACRONYMS}

BEA Battelle Energy Alliance

$\mathrm{CH} \quad$ contact-handled

DOE Department of Energy

INTEC Idaho Nuclear Technology and Engineering Center

IWTS Integrated Waste Tracking System

LLW low-level waste

MSCC Material Security and Consolidation Complex

MSCF Materials and Security Consolidation Facility

NNSS Nevada National Security Site

RCRA Resource Conservation and Recovery Act

RWMB radioactive waste management basis

POC point of contact

TRU transuranic

TSCA Toxic Substances Control Act 


\title{
Materials and Security Consolidation Complex Facilities Radioactive Waste Management Basis and DOE Manual 435.1-1 Compliance Tables
}

\author{
1. INTRODUCTION
}

The U.S. Department of Energy (DOE) ensures that DOE radioactive waste is managed in a manner that is protective of the worker and public health and the environment through DOE Order 435.1, "Radioactive Waste Management," and its associated manual (DOE Manual 435.1-1, "Radioactive Waste Management Manual") and guidance (DOE Guide 435.1-1, "Implementation Guide for Use with DOE M 435.1-1"). As required by DOE Manual 435.1-1, I.F.(2), field element managers are responsible for ensuring that a radioactive waste management basis (RWMB) is developed and maintained for each DOE radioactive waste management facility, operation, and activity. The RWMB must do the following:

- Reference or define the conditions under which the facility may operate based on the radioactive waste management documentation

- Include the applicable elements indentified in the specific waste type chapters of the manual (DOE Manual 435.1-1)

- Be developed using the graded approach process.

The specific waste type chapters of DOE Manual 435.1-1 are high-level waste (Chapter II), transuranic (TRU) waste (Chapter III), and low-level waste (LLW) (Chapter IV). The RWMB is required to consist of "physical and administrative controls to ensure the protection of workers, the public, and the environment." For TRU waste and LLW, the RWMB includes the following specific waste management controls:

- For generators, the waste certification program

- For treatment facilities and storage facilities, the waste acceptance requirements and the waste certification program

- For disposal facilities, the performance assessment, composite analysis, disposal authorization statement, closure plan, waste acceptance requirements, and monitoring plan.

Similar waste management controls are specified for high-level waste generators and high-level waste pretreatment, treatment, and storage facilities.

However, consistent with the graded approach provided in the DOE guidance, the required elements of the RWMB vary with the type of waste management operation or facility and the types of hazards associated with the facility. Therefore, the elements that are included in the guidance for each waste type chapter of the manual are not to be considered a complete list of elements. For example, the elements determined to be applicable to the RWMB for a facility may include the facility safety basis; authorization basis; operational procedures; radiation protection controls and procedures; waste characterization and certification plan; waste acceptance criteria; waste tracking and records management; waste storage and staging requirements; facility monitoring; quality assurance; and regulatory permits and appropriate documentation for permitted facilities.

The purpose of this document is to present a RWMB for the Materials and Security Consolidation Complex (MSCC) facilities that manage radioactive waste and DOE Manual 435.1-1 facility compliance information tables for the MSCC facilities. The facility RWMB comprises existing laboratory-wide and facility-specific documents. The DOE Manual 435.1-1 facility compliance information tables show how each facility meets the DOE Manual 435.1-1 requirement for a waste type and serves as a tool to develop the RWMB. The tables provide information that Battelle Energy Alliance (BEA) and facility management 
officials can use to apply the graded approach emphasized in DOE Order 435.1 and its associated manual and guidance. This document is intended to support the summary RWMB (PLN-3941) for the facilities managing radioactive waste at MSCC. The summary RWMB is to be submitted to the DOE field element manager for approval.

\section{METHODOLOGY}

The following methodology was used to prepare preliminary RWMB and facility compliance information tables for the MSCC facilities:

- A kick-off meeting was held with BEA officials. At this meeting, a preliminary list of MSCC facilities that should be included in this effort was verified. Based on the information obtained at this meeting, the list of facilities was modified slightly. The BEA officials also provided the point of contact (POC) for each facility that could provide facility radioactive waste management information.

- Interviews were conducted with the primary POCs to discuss radioactive waste management procedures and programs at each facility. The interviews were conducted between August 1, 2011, and September 1, 2011.

- Based on the information received from the interviews and analysis of the procedures cited by the facility POCs and found through the Electronic Document Management System, initial draft tables that describe facility-level compliance with DOE Manual 435.1-1 requirements for each facility and each waste type managed at the facility were developed.

- A review meeting with the facility POCs and BEA management officials, which was intended to serve as verification of the information presented in the initial draft tables, was cancelled. Subsequent attempts to re-schedule this meeting failed. The meeting also would have allowed BEA management officials to discuss and make decisions regarding the potential compliance issues unique to these facilities.

- The tables were revised based only on input received via follow-up interviews with the facility POCs that responded to the attempts to reach them.

- For each facility, a preliminary RWMB and a list of areas requiring further BEA and facility management actions were developed based on information from the revised tables.

In developing and reviewing the compliance information and preliminary RWMB, the graded approach that DOE specifies for developing the RWMB and that is emphasized throughout the DOE Guide 435.1-1 guidance was used. The guidance also states that, when possible, existing processes, programs, and documentation should be considered as possible ways to comply with DOE Manual 435.1-1 requirements (DOE Guide 435.1-1).

Both the manual and associated guidance were considered in developing and reviewing the preliminary RWMB. DOE Manual 435.1-1 describes the requirements and establishes specific responsibilities for implementing DOE Order 435.1 for management of DOE high-level waste, TRU waste, LLW, and the radioactive component of mixed waste. DOE Guide 435.1-1 was developed to aid in implementing DOE Manual 435.1-1 requirements. The guide aids in understanding what is necessary to attain compliance, facilitates effective and efficient implementation of the requirements, and offers acceptable ways to implement the requirements. The guide is not meant to be viewed as additional or mandatory requirements. The guide emphasizes consideration of situation-specific attributes and application of the graded approach to dictate the rigor applied to implementation (DOE Guide 435.1-1 and DOE Manual 435.1-1). 


\section{SCOPE}

The MSCC consists of six facilities; however, only the following facilities that generate radiological waste are considered in this report:

- CPP-651, Materials and Security Consolidation Facility (MSCF)

- CPP-653, Cold Waste Handling Facility

- CPP-1634, Technology Development Facility.

\section{FACILITY RADIOACTIVE WASTE MANAGEMENT BASIS AND DOE MANUAL 435.1-1 COMPLIANCE TABLES}

This section presents the RWMB and DOE Manual 435.1-1 compliance tables for the following MSCC facilities:

- CPP-651, MSCF (Subsection 4.1)

- CPP-653, Cold Waste Handling Facility (Subsection 4.2)

- CPP-1634, Technology Development Facility (Subsection 4.3).

For each MSCC building housing these facilities, a brief facility overview is provided. The overview includes a facility description, the facility's safety basis classification, the radioactive waste management activities and waste types for the facility, a list of RWMB documents and programs for the facility, and a list of compliance requirements needing further BEA management action.

The DOE Manual 435.1-1 compliance information table for each radioactive waste type managed at each MSCC facility also is provided for each facility. Each table shows the DOE Manual 435.1-1 requirement, facility compliance information for each requirement, and compliance issues for consideration by INL, BEA, and facility management, as appropriate. In some cases, excerpts from the DOE Guide 435.1-1 guidance associated with the DOE Manual 435.1-1 requirement are included. These excerpts are included to provide additional context and information about the requirement. However, the complete guidance citation should be consulted for decision-making.

\subsection{CPP-651, Materials and Security Consolidation Facility}

1. Facility description: MSCF (formerly the Unirradiated Fuel Storage Facility), is a two-compartment, inner-vault building surrounded by an outer, reinforced concrete shell. The original facility that was constructed in 1975 consisted of the inner shell that contained two storage vaults. In 1984, the original facility was enclosed within an outer, reinforced, concrete shell to provide upgraded security and safeguards protection for the stored material. The north, east, and south walls of the outer shell have gravel berms with concrete slabs covering the berms. In addition to the two inner vaults, the shell encloses a receiving area on the west side and an annulus on the other three sides of the inner vaults. In 1994, storage wells in a raised concrete floor were installed in the annulus surrounding the storage vaults on the north, east, and south sides of the inner vault building.

There are access doors on the south and west sides of the facility. The access doors on the south side of the facility consist of a set of two hydraulically operated, east-facing, outer security (lanai) doors and a set of five chevron, hydraulically operated, south-facing, inner security doors. There is an enclosed material receiving vestibule between the outer security (lanai) doors and the inner security (chevron) doors. The distance between the outer and inner doors is approximately $25 \mathrm{ft}$. After entering the material receiving vestibule and moving west approximately $10 \mathrm{ft}$, a 90 -degree turn to the north is required to enter the receiving area of MSCF through the inner doors. The access door on the west side of the facility is a pneumatically-operated steel door with manual override. The door 
connects the receiving area to the vestibule on the west side of the facility. A security fence encircles MSCF and extends south to enclose both sides of the area between CPP-1674and MSCF.

The function of MSCF includes material handling and storage and other activities that may include the following:

- $\quad$ Receiving material-loaded, approved storage containers

- Transferring material-loaded, approved storage containers to storage locations

- Retrieving material-loaded, approved storage containers from storage for inspection, inventory, or other purposes

- Shipping material-loaded, approved storage containers to other facilities within or beyond the INL

- Maintenance and facility modification activities.

Functional areas and structures at MSCF include the (1) access building (CPP-1674), (2) caged walkway, (3) outer security doors, (4) vestibules, (5) inner security doors, (6) outer concrete shell, (7) inner vault structure, (8) roof, (9) interior walls, (10) receiving area, (11) Area 100 fuel handling area, (12) north vault, (13) south vault, and (14) annulus.

The primary MSCF operations, as mentioned above, include the various aspects of material handling and storage. Material receiving and shipping occurs into or out of the receiving area. Other material handling occurs between the receiving area and the vaults (north and south).

The facility also includes equipment such as heaters for temperature control, a blower for air exhaust, a drum lifter and dolly, and hoists and associated rigging. Utilities and special support functions, including electrical power, communications, and alarms in the north and south vaults, are provided for MSCF.

2. Hazard category: Hazard Category 2 nuclear facility

3. Radioactive waste managed at this facility: Routine contact-handled LLW is generated and staged at this facility. Containers of process material also are received from the Transient Reactor Experiment and Test Facility warehouse.

\section{RWMB documents/programs:}

a) Safety basis/hazard analysis:

- SAR-115, "Safety Analysis Report for the Unirradiated Fuel Storage Facility." Note: SAR/TSR-416 will replace SAR-115 beginning October 1, 2012.

b) Laboratory-wide:

- Form 435.39, "Waste Determination and Disposition Form (WDDF)"

- Form 435.42, "Radioactive Waste Inventory Sheet"

- Form 441.A34, "INL Radiological Control Required Surveys"

- LI-435, "Waste Management Routine Field Activities"

- LRD-15001, "Radiological Control Manual"

- LWP-13840, "Management of Issues, Observations, and Noteworthy Practices"

- LWP-14002, "Timeout and Stop Work Authority"

- LWP-15011, "Radioactive Material Areas and Radioactive Storage Areas"

- LWP-17000, "Waste Management"

- MCP-139, "Radiological Surveys"

- MCP-17000, "Waste Generator Services Waste Management" 
- MCP-17500, "Waste Generator Services Certification of Waste Shipments to the Nevada Test Site"

- PDD-17000, "Waste Management Program"

- PLN-114, "INL Emergency Plan/RCRA Contingency Plan"

- PLN-522, "Quality Assurance Program Plan for the Waste Management/Waste Certification Program"

c) Facility-specific:

- IAG-514, "INL Authorization Agreement for Understanding Between Battelle Energy Alliance (BEA) and CH2M-WGI (CWI) for the Turnover and Operation of CPP-609, CPP-651, CPP-653, CPP-661, CPP-1634, and CPP-1674."

LLW is managed at this facility. Table 1 presents the facility compliance information for Chapter IV, "Low-level Waste Requirements."

Table 1. CPP-651, Materials and Security Consolidation Facility, DOE Manual 435.1-1 low-level waste requirements and facility compliance information.

\begin{tabular}{|c|c|}
\hline \multicolumn{2}{|c|}{ Facility Name: CPP-651, Materials and Security Consolidation Facility } \\
\hline Chapter IV, LLW Requirements & Facility Compliance Information \\
\hline $\begin{array}{l}\text { A. Definition of Low-Level Waste. Low-level radioactive waste is } \\
\text { radioactive waste that is not high-level radioactive waste, spent } \\
\text { nuclear fuel, transuranic waste, byproduct material (as defined in } \\
\text { section 11e.(2) of the Atomic Energy Act of 1954, as amended), or } \\
\text { naturally occurring radioactive material. } \\
\text { (From DOE G 435.1-1 Chapter IV: Low-level radioactive waste is } \\
\text { defined by what it is not. The guidance on definitions in Chapters II } \\
\text { and III should be consulted first for making a determination on how } \\
\text { to properly manage a suspect waste stream.) }\end{array}$ & $\begin{array}{l}\text { This requirement provides the criteria for } \\
\text { determining which DOE radioactive waste } \\
\text { is to be managed as LLW in accordance } \\
\text { with DOE Manual } 435.1-1 \text {, Chapter IV. } \\
\text { Radioactive waste managed at this facility } \\
\text { under the requirements of this chapter is } \\
\text { not managed under the requirements of } \\
\text { DOE Manual } 435.1-1 \text { Chapter II or } \\
\text { Chapter III. }\end{array}$ \\
\hline $\begin{array}{l}\text { B. Management of Specific Wastes. The following provide for } \\
\text { management of specific wastes as low-level waste in accordance } \\
\text { with the requirements in this Chapter: }\end{array}$ & See (1), (2), (3), and (4) below. \\
\hline $\begin{array}{l}\text { (1) Mixed Low-Level Waste. Low-level waste determined to } \\
\text { contain both source, special nuclear, or byproduct material } \\
\text { subject to the Atomic Energy Act of 1954, as amended, and a } \\
\text { hazardous component subject to the Resource Conservation and } \\
\text { Recovery Act (RCRA), as amended, shall be managed in } \\
\text { accordance with the requirements of RCRA and DOE O 435.1, } \\
\text { Radioactive Waste Management, and this Manual. }\end{array}$ & $\begin{array}{l}\text { Not applicable (NA); this facility does not } \\
\text { manage Resource Conservation Recovery } \\
\text { Act (RCRA)-regulated mixed LLW. }\end{array}$ \\
\hline $\begin{array}{l}\text { (2) TSCA-Regulated Waste. Low-level waste containing } \\
\text { polychlorinated biphenyls, asbestos, or other such regulated } \\
\text { toxic components shall be managed in accordance with } \\
\text { requirements derived from the Toxic Substances Control Act, as } \\
\text { amended, DOE O 435.1, Radioactive Waste Management, and } \\
\text { this Manual. }\end{array}$ & $\begin{array}{l}\text { NA; this facility does not manage Toxic } \\
\text { Substances Control Act (TSCA)-regulated } \\
\text { waste. }\end{array}$ \\
\hline $\begin{array}{l}\text { (3) Accelerator-Produced Waste. Radioactive waste produced as a } \\
\text { result of operations of DOE accelerators is low-level waste and } \\
\text { shall be managed in accordance with DOE O 435.1, Radioactive } \\
\text { Waste Management, and this Manual, and all applicable Federal } \\
\text { or State requirements. }\end{array}$ & $\begin{array}{l}\text { NA; this facility does not manage } \\
\text { accelerator-produced waste. }\end{array}$ \\
\hline $\begin{array}{l}\text { (4) } 11 \mathrm{e} .(2) \text { and Naturally Occurring Radioactive Material. Small } \\
\text { quantities of } 11 \mathrm{e} .(2) \text { byproduct material and naturally occurring } \\
\text { radioactive material may be managed as low-level waste }\end{array}$ & $\begin{array}{l}\text { NA; this facility does not manage naturally } \\
\text { occurring radioactive material. }\end{array}$ \\
\hline
\end{tabular}


Table 1. (continued).

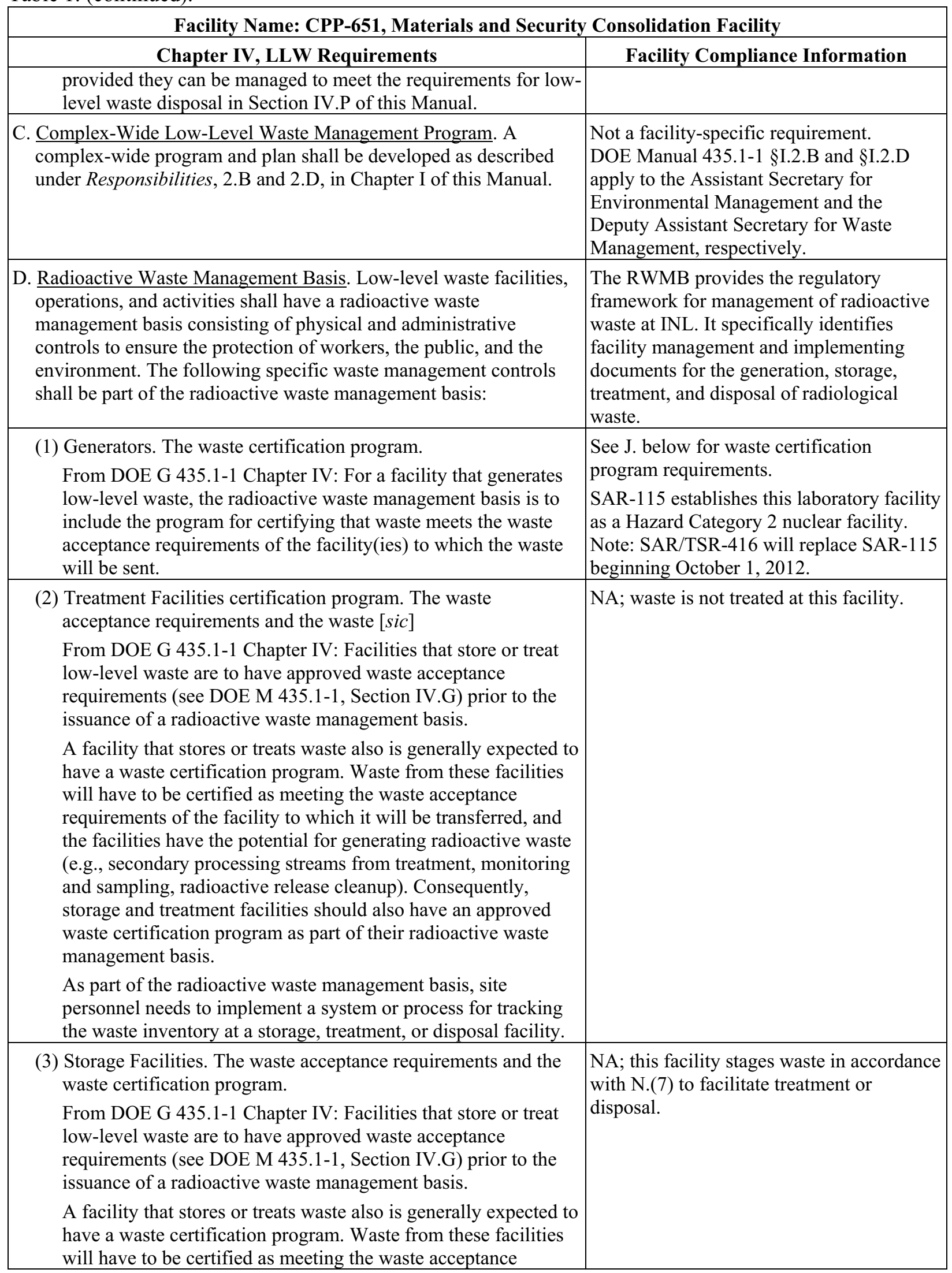


Table 1. (continued).

\begin{tabular}{|c|c|}
\hline \multicolumn{2}{|c|}{ Facility Name: CPP-651, Materials and Security Consolidation Facility } \\
\hline Chapter IV, LLW Requirements & Facility Compliance Information \\
\hline $\begin{array}{l}\text { requirements of the facility to which it will be transferred, and } \\
\text { the facilities have the potential for generating radioactive waste } \\
\text { (e.g., secondary processing streams from treatment, monitoring } \\
\text { and sampling, radioactive release cleanup). Consequently, } \\
\text { storage and treatment facilities should also have an approved } \\
\text { waste certification program as part of their radioactive waste } \\
\text { management basis. }\end{array}$ & \\
\hline $\begin{array}{l}\text { As part of the radioactive waste management basis, site } \\
\text { personnel needs to implement a system or process for tracking } \\
\text { the waste inventory at a storage, treatment, or disposal facility. }\end{array}$ & \\
\hline $\begin{array}{l}\text { (4) Disposal Facilities. The performance assessment, composite } \\
\text { analysis, disposal authorization statement, closure plan, waste } \\
\text { acceptance requirements, and monitoring plan. }\end{array}$ & NA; this facility is not a disposal facility. \\
\hline $\begin{array}{l}\text { E. Contingency Actions. The following requirements are in addition to } \\
\text { those in Chapter I of this Manual [DOE M 435.1-1 §I.1.E(5)]. }\end{array}$ & $\begin{array}{l}\text { DOE Manual 435.1-1 §I.1.E(5) addresses } \\
\text { the sitewide emergency management } \\
\text { system. The INL plan is provided in } \\
\text { PLN-114. }\end{array}$ \\
\hline $\begin{array}{l}\text { (1) Contingency Storage. For off-normal or emergency situations } \\
\text { involving high activity or high hazard liquid low-level waste } \\
\text { storage or treatment, spare capacity with adequate capabilities } \\
\text { shall be maintained to receive the largest volume of liquid } \\
\text { contained in any one storage tank or treatment facility. Tanks or } \\
\text { other facilities that are designated low-level waste contingency } \\
\text { storage shall be maintained in an operational condition when } \\
\text { waste is present and shall meet the requirements of DOE O } \\
\text { 435.1, Radioactive Waste Management, and this Manual. }\end{array}$ & NA; this facility does not store liquid LLW. \\
\hline $\begin{array}{l}\text { From DOE G 435.1-1 Chapter IV: Compliance with these } \\
\text { requirements is demonstrated if adequate spare capacity and } \\
\text { transfer equipment exists for emergency transfers of all high } \\
\text { activity and high hazard liquid low-level waste. In addition, the } \\
\text { capability to perform emergency transfers is demonstrated by } \\
\text { having waste transfer routings identified, operational procedures } \\
\text { to direct transfers, staff trained to the procedures, and records } \\
\text { showing that the spare capacity and transfer capability are kept } \\
\text { in operating condition. }\end{array}$ & \\
\hline $\begin{array}{l}\text { (2) Transfer Equipment. Pipelines and auxiliary facilities necessary } \\
\text { for the transfer of high activity or high hazard liquid low-level } \\
\text { waste to contingency storage shall be maintained in an } \\
\text { operational condition when waste is present and shall meet the } \\
\text { requirements of DOE O 435.1, Radioactive Waste Management, } \\
\text { and this Manual. }\end{array}$ & $\begin{array}{l}\text { NA; this facility does not store or treat } \\
\text { liquid LLW. }\end{array}$ \\
\hline $\begin{array}{l}\text { From DOE G 435.1-1 Chapter IV: Compliance with these } \\
\text { requirements is demonstrated if adequate spare capacity and } \\
\text { transfer equipment exists for emergency transfers of all high } \\
\text { activity and high hazard liquid low-level waste. In addition, the } \\
\text { capability to perform emergency transfers is demonstrated by } \\
\text { having waste transfer routings identified, operational procedures } \\
\text { to direct transfers, staff trained to the procedures, and records } \\
\text { showing that the spare capacity and transfer capability are kept } \\
\text { in operating condition. }\end{array}$ & \\
\hline
\end{tabular}


Table 1. (continued).

\begin{tabular}{|c|c|}
\hline \multicolumn{2}{|c|}{ Facility Name: CPP-651, Materials and Security Consolidation Facility } \\
\hline Chapter IV, LLW Requirements & Facility Compliance Information \\
\hline $\begin{array}{l}\text { F. Corrective Actions. I of this Manual. The following requirements } \\
\text { are in addition to those in Chapter [sic] } \\
\text { From DOE G 435.1-1 Chapter IV: Compliance with DOE M 435.1- } \\
1 \text { §I.2.G.(1) is demonstrated by records showing what corrective } \\
\text { actions were taken to remedy situations in the radioactive waste } \\
\text { management system. } \\
\text { Compliance with DOE M 435.1-1 §I.2.G.(2) is demonstrated by } \\
\text { having the necessary procedures, mechanisms, and training in place } \\
\text { to effect shutdown or curtailment of activities which pose an } \\
\text { imminent danger or other serious hazard to workers or the public, } \\
\text { or are not protective of the environment. }\end{array}$ & $\begin{array}{l}\text { The INL-wide procedure addressing } \\
\text { problem identification as required by } \\
\text { DOE Manual } 435.1-1 \text { §I.2.G.(1) is } \\
\text { LWP-13840, which implements the } \\
\text { laboratory's corrective action system. } \\
\text { The INL-wide procedure addressing } \\
\text { shutdown or curtailment of activities as } \\
\text { required by DOE Manual } 435.1-1 \\
\text { §I.2.G.(2) is LWP-14002. }\end{array}$ \\
\hline $\begin{array}{l}\text { (1) Order Compliance. Corrective actions shall be implemented } \\
\text { whenever necessary to ensure the requirements of DOE O } \\
\text { 435.1, Radioactive Waste Management, and this Manual are } \\
\text { met. } \\
\text { From DOE G 435.1-1 Chapter IV: If a facility or activity can be } \\
\text { allowed to operate while a noncompliant or hazardous condition } \\
\text { exists, the allowance and any associated limitations must be } \\
\text { defined as part of the facility or activity's radioactive waste } \\
\text { management basis, identified as a configuration controlled item } \\
\text { in a configuration management plan or included in a revision or } \\
\text { modification to an operating procedure or similar controlled } \\
\text { documentation. } \\
\text { Compliance with this requirement is demonstrated if a } \\
\text { corrective action system addresses noncompliant or hazardous } \\
\text { situations involving low-level waste management facilities in a } \\
\text { systematic fashion, and allows identification of problems by all } \\
\text { personnel. }\end{array}$ & See F. above. \\
\hline $\begin{array}{l}\text { (2) Operations Curtailment. Operations shall be curtailed or } \\
\text { facilities shut down for failure to establish, maintain, or operate } \\
\text { consistent with an approved radioactive waste management } \\
\text { basis. } \\
\text { From DOE G 435.1-1 Chapter IV: Compliance with this } \\
\text { requirement is demonstrated with a documented system of } \\
\text { routine assessments to determine whether waste management } \\
\text { activities and facilities are operating in accordance with an } \\
\text { approved radioactive waste management basis that provides for } \\
\text { graded limitations that can be placed on activities and } \\
\text { operations that do not have, or are operating outside of, an } \\
\text { approved radioactive waste management basis, including } \\
\text { shutdown of the facility. }\end{array}$ & $\begin{array}{l}\text { The approved RWMB establishes the } \\
\text { current compliance status at each } \\
\text { radioactive waste management facility. } \\
\text { Facility assessments are scheduled to } \\
\text { ensure waste management activities are } \\
\text { conducted in accordance with the approved } \\
\text { RWMB. }\end{array}$ \\
\hline $\begin{array}{l}\text { G. Waste Acceptance. The following requirements are in addition to } \\
\text { those in Chapter I of this Manual [DOE M 435.1-1 §I.2.F(6)]. }\end{array}$ & $\begin{array}{l}\text { DOE Manual 435.1-1 §I.2.F(6) applies to } \\
\text { field element managers. }\end{array}$ \\
\hline $\begin{array}{l}\text { (1) Technical and Administrative. Waste acceptance requirements } \\
\text { for all low-level waste storage, treatment, or disposal facilities, } \\
\text { operations, and activities shall specify, at a minimum, the } \\
\text { following: } \\
\text { From DOE G } 435.1-1 \text { Chapter IV: Compliance with these waste } \\
\text { acceptance requirements is demonstrated if they are }\end{array}$ & $\begin{array}{l}\text { NA; this facility does not accept LLW from } \\
\text { other facilities. }\end{array}$ \\
\hline
\end{tabular}


Table 1. (continued).

\begin{tabular}{|c|c|}
\hline \multicolumn{2}{|c|}{ Facility Name: CPP-651, Materials and Security Consolidation Facility } \\
\hline Chapter IV, LLW Requirements & Facility Compliance Information \\
\hline $\begin{array}{l}\text { documented, contain clear and precise criteria specifying the } \\
\text { radionuclide limits in the form of contents or concentrations that } \\
\text { can be accepted, the limitations and prohibitions on waste forms } \\
\text { and packages that can be received, and the limits, prohibitions, } \\
\text { or instructions concerning any other technical information so } \\
\text { that the waste is compatible with the safety basis of the facility, } \\
\text { and which will result in acceptable waste at subsequent steps in } \\
\text { managing the low-level waste. }\end{array}$ & \\
\hline $\begin{array}{l}\text { (a) Allowable activities and/or concentrations of specific } \\
\text { radionuclides. }\end{array}$ & See (1) above. \\
\hline $\begin{array}{l}\text { (b) Acceptable waste form and/or container requirements that } \\
\text { ensure the chemical and physical stability of waste under } \\
\text { conditions that might be encountered during transportation, } \\
\text { storage, treatment, or disposal. }\end{array}$ & See (1) above. \\
\hline $\begin{array}{l}\text { (c) Restrictions or prohibitions on waste, materials, or } \\
\text { containers that may adversely affect waste handlers or } \\
\text { compromise facility or waste container performance. }\end{array}$ & See (1) above. \\
\hline $\begin{array}{l}\text { (d) The following are additional waste acceptance requirements } \\
\text { that shall be specified in low-level waste disposal facility } \\
\text { waste acceptance requirements: }\end{array}$ & See (1) above. \\
\hline $\begin{array}{l}1 \text { Low-level waste must contribute to and not detract from } \\
\text { achieving long-term stability of the facility, minimizing } \\
\text { the need for long-term active maintenance, minimizing } \\
\text { subsidence, and minimizing contact of water with waste. } \\
\text { Void spaces within the waste and, if containers are used, } \\
\text { between the waste and its container shall be reduced to the } \\
\text { extent practical. }\end{array}$ & See (1) above. \\
\hline $\begin{array}{l}2 \text { Liquid low-level waste or low-level waste containing free } \\
\text { liquid must be converted into a form that contains as little } \\
\text { freestanding liquid as is reasonably achievable, but in no } \\
\text { case shall the liquid exceed } 1 \text { percent of the waste volume } \\
\text { when the low-level waste is in a disposal container, or } 0.5 \\
\text { percent of the waste volume after it is processed to a stable } \\
\text { form. }\end{array}$ & See (1) above. \\
\hline $\begin{array}{l}3 \text { Low-level waste must not be readily capable of detonation } \\
\text { or of explosive decomposition or reaction at anticipated } \\
\text { pressures and temperatures, or of explosive reaction with } \\
\text { water. Pyrophoric materials contained in waste shall be } \\
\text { treated, prepared, and packaged to be nonflammable. }\end{array}$ & See (1) above. \\
\hline $\begin{array}{l}4 \text { Low-level waste must not contain, or be capable of } \\
\text { generating by radiolysis or biodegradation, quantities of } \\
\text { toxic gases, vapors, or fumes harmful to the public or } \\
\text { workers or disposal facility personnel, or harmful to the } \\
\text { long-term structural stability of the disposal site. }\end{array}$ & See (1) above. \\
\hline $\begin{array}{l}5 \text { Low-level waste in a gaseous form must be packaged such } \\
\text { that the pressure does not exceed } 1.5 \text { atmospheres absolute } \\
\text { at } 20 \mathrm{C} \text {. }[\text { sic }]\end{array}$ & See (1) above. \\
\hline $\begin{array}{l}\text { (e) The basis, procedures, and levels of authority required for } \\
\text { granting exceptions to the waste acceptance requirements, }\end{array}$ & See (1) above. \\
\hline
\end{tabular}


Table 1. (continued).

\begin{tabular}{|c|c|}
\hline \multicolumn{2}{|c|}{ Facility Name: CPP-651, Materials and Security Consolidation Facility } \\
\hline Chapter IV, LLW Requirements & Facility Compliance Information \\
\hline $\begin{array}{l}\text { which shall be contained in each facility's waste acceptance } \\
\text { documentation. Each exception request shall be documented, } \\
\text { including its disposition as approved or not approved. }\end{array}$ & \\
\hline $\begin{array}{l}\text { From DOE G 435.1-1 Chapter IV: Waste acceptance } \\
\text { requirements are acceptable if they are documented and } \\
\text { contain a clear description of the procedure and bases for } \\
\text { obtaining an exception or deviation to the acceptance criteria } \\
\text { for low-level waste to be received at the facility. }\end{array}$ & \\
\hline $\begin{array}{l}\text { (2) Evaluation and Acceptance. The receiving facility shall evaluate } \\
\text { waste for acceptance, including confirmation that the technical } \\
\text { and administrative requirements have been met. A process for } \\
\text { the disposition of non-conforming wastes shall be established. }\end{array}$ & See (1) above. \\
\hline $\begin{array}{l}\text { From DOE G 435.1-1 Chapter IV: Compliance with the waste } \\
\text { acceptance requirements for a low-level waste management } \\
\text { facility is demonstrated if they include a process for evaluation } \\
\text { and acceptance of incoming waste to ensure the acceptance } \\
\text { criteria of the facility receiving the waste are met that includes } \\
\text { one of or a combination of: (1) testing, sampling, and analysis } \\
\text { of representative samples of waste upon receipt; (2) testing, } \\
\text { sampling, and analysis of split samples of waste taken at the } \\
\text { generator site; (3) evaluation of testing, sampling, and analysis } \\
\text { of data provided by the generator, or (4) audits, reviews, } \\
\text { surveillance, or observations of generator waste certification } \\
\text { programs and characterization activities. Additionally, } \\
\text { acceptable waste acceptance requirements for a storage, } \\
\text { treatment or disposal facility will have documented procedures } \\
\text { and actions to be taken if a waste that does not conform to the } \\
\text { waste acceptance criteria is received at the facility. }\end{array}$ & \\
\hline $\begin{array}{l}\text { H. Waste Generation Planning. The following requirements are in } \\
\text { addition to those in Chapter I of this Manual [DOE M 435.1-1 } \\
\S I .2 . F(7)] \text {. }\end{array}$ & $\begin{array}{l}\text { DOE Manual 435.1-1 §I.2.F(7) applies to } \\
\text { field element managers. }\end{array}$ \\
\hline $\begin{array}{l}\text { (1) Life-Cycle Planning. Prior to waste generation, planning shall } \\
\text { be performed to address the entire life cycle for all low-level } \\
\text { waste streams. }\end{array}$ & $\begin{array}{l}\text { PDD-17000 and LWP-17000 provide } \\
\text { direction to the waste generators for waste } \\
\text { generation planning to address the entire }\end{array}$ \\
\hline $\begin{array}{l}\text { From DOE G 435.1-1 Chapter IV: Compliance with this } \\
\text { planning requirement is demonstrated by the individual sites } \\
\text { establishing a process for evaluating the life-cycle of low-level } \\
\text { waste prior to its generation, including the identification of low- } \\
\text { level wastes with no path to disposal and appropriate records } \\
\text { justifying the newly generated low-level waste stream(s), and } \\
\text { site personnel possessing planning information showing the } \\
\text { location(s) where low-level waste will be stored, treated, and/or } \\
\text { disposed along with a confirmation that the personnel managing } \\
\text { the facilities agree that the low-level waste may be managed at } \\
\text { those facilities. }\end{array}$ & $\begin{array}{l}\text { life cycle. } \\
\text { Form } 435.39 \text { and Form } 435.42 \text { are used to } \\
\text { identify radioactive LLW. }\end{array}$ \\
\hline $\begin{array}{l}\text { (2) Waste with No Identified Path to Disposal. Low-level waste } \\
\text { streams with no identified path to disposal shall be generated } \\
\text { only in accordance with approved conditions which, at a } \\
\text { minimum, shall address: }\end{array}$ & $\begin{array}{l}\text { This facility is not generating radioactive } \\
\text { waste that does not have an identified path } \\
\text { to disposal. }\end{array}$ \\
\hline (a) Programmatic need to generate the waste; & See (2) above. \\
\hline
\end{tabular}


Table 1. (continued).

\begin{tabular}{|c|c|}
\hline \multicolumn{2}{|c|}{ Facility Name: CPP-651, Materials and Security Consolidation Facility } \\
\hline Chapter IV, LLW Requirements & Facility Compliance Information \\
\hline $\begin{array}{l}\text { (b) Characteristics and issues preventing the disposal of the } \\
\text { waste; }\end{array}$ & See (2) above. \\
\hline (c) Safe storage of the waste until disposal can be achieved; and & See (2) above. \\
\hline (d) Activities and plans for achieving final disposal of the waste. & See (2) above. \\
\hline $\begin{array}{l}\text { I. Waste Characterization. Low-level waste shall be characterized } \\
\text { using direct or indirect methods, and the characterization } \\
\text { documented in sufficient detail to ensure safe management and } \\
\text { compliance with the waste acceptance requirements of the facility }\end{array}$ & $\begin{array}{l}\text { MCP-17000 } \$ 4 \text { specifies the requirements } \\
\text { for preparing an Integrated Waste Tracking } \\
\text { System (IWTS) profile that captures waste } \\
\text { characterization information. }\end{array}$ \\
\hline $\begin{array}{l}\text { receiving the waste. } \\
\text { From DOE G 435.1-1 Chapter IV: Compliance with this } \\
\text { requirement is demonstrated by a program for documenting and the } \\
\text { existence of records that document the process for acquiring and } \\
\text { verifying the validity of low-level waste characterization data } \\
\text { acquired through the use of direct or indirect methods. }\end{array}$ & $\begin{array}{l}\text { Individual laboratory projects have } \\
\text { project-specific laboratory instructions that } \\
\text { address management of LLW in } \\
\text { accordance with INL Manual } 17 \text { waste } \\
\text { management requirements. }\end{array}$ \\
\hline $\begin{array}{l}\text { (1) Data Quality Objectives. The data quality objectives process, or } \\
\text { a comparable process, shall be used for identifying } \\
\text { characterization parameters and acceptable uncertainty in } \\
\text { characterization data. }\end{array}$ & $\begin{array}{l}\text { Radioactive waste management facilities } \\
\text { characterize waste in accordance with the } \\
\text { requirements of the receiving storage, } \\
\text { treatment, or disposal facility. The }\end{array}$ \\
\hline $\begin{array}{l}\text { From DOE G 435.1-1 Chapter IV: Compliance with this } \\
\text { requirement is demonstrated by the documented use of a data } \\
\text { quality objectives or a comparable process for determining the } \\
\text { type, quantity, and quality of characterization data needed to } \\
\text { safely manage low-level waste. }\end{array}$ & $\begin{array}{l}\text { documented use of a data quality objectives } \\
\text { process, or comparable process, was not } \\
\text { identified for this facility. }\end{array}$ \\
\hline $\begin{array}{l}\text { (2) Minimum Waste Characterization. Characterization data shall, } \\
\text { at a minimum, include the following information relevant to the } \\
\text { management of the waste: }\end{array}$ & $\begin{array}{l}\text { MCP-17000 } \$ 4 \text { specifies the requirements } \\
\text { for preparing an IWTS profile that captures } \\
\text { waste characterization information. }\end{array}$ \\
\hline $\begin{array}{l}\text { From DOE G 435.1-1 Chapter IV: Compliance with this } \\
\text { requirement is demonstrated by the existence of a program or } \\
\text { procedure for determining and records that document } \\
\text { characterization of low-level waste consistent with the } \\
\text { minimum characterization data requirements. }\end{array}$ & $\begin{array}{l}\text { Individual laboratory projects have } \\
\text { project-specific laboratory instructions that } \\
\text { address the management of LLW in } \\
\text { accordance with INL Manual } 17 \text { waste } \\
\text { management requirements. }\end{array}$ \\
\hline (a) Physical and chemical characteristics; & See (2) above. \\
\hline $\begin{array}{l}\text { (b) Volume, including the waste and any stabilization or } \\
\text { absorbent media; }\end{array}$ & See (2) above. \\
\hline (c) Weight of the container and contents; & See (2) above. \\
\hline $\begin{array}{l}\text { (d) Identities, activities, and concentrations of major } \\
\text { radionuclides; }\end{array}$ & See (2) above. \\
\hline (e) Characterization date; & See (2) above. \\
\hline (f) Generating source; and & See (2) above. \\
\hline $\begin{array}{l}\text { (g) Any other information which may be needed to prepare and } \\
\text { maintain the disposal facility performance assessment, or } \\
\text { demonstrate compliance with applicable performance } \\
\text { objectives. }\end{array}$ & See (2) above. \\
\hline $\begin{array}{l}\text { J. Waste Certification. A waste certification program shall be } \\
\text { developed, documented, and implemented to ensure that the waste } \\
\text { acceptance requirements of facilities receiving low-level waste for }\end{array}$ & $\begin{array}{l}\text { MCP- } 17000 \S 4 \text { specifies the requirements } \\
\text { for preparing an IWTS profile that captures } \\
\text { waste certification information. }\end{array}$ \\
\hline & MCP-17500 provides the Waste Generator \\
\hline
\end{tabular}


Table 1. (continued).

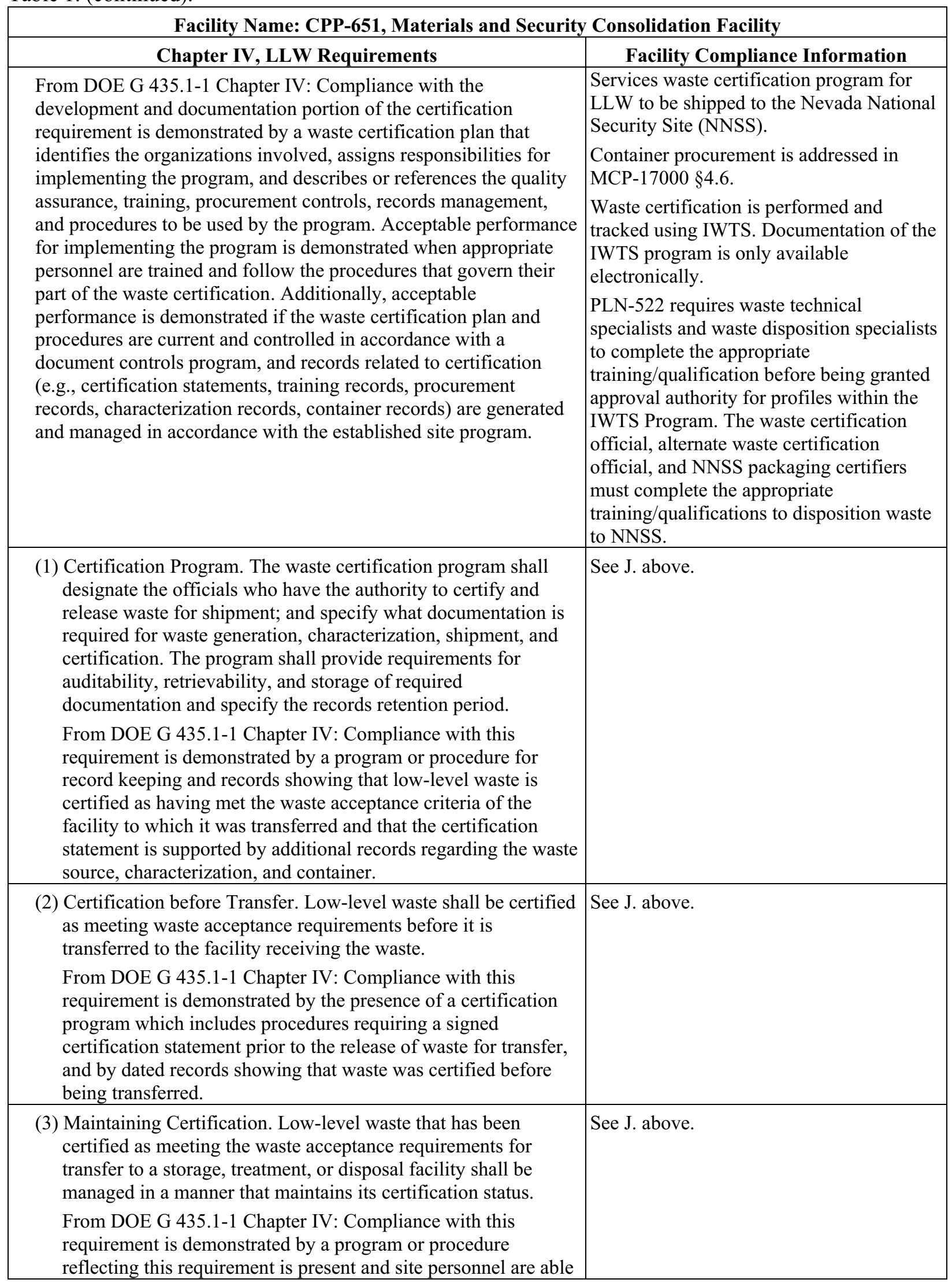


Table 1. (continued).

\begin{tabular}{|c|c|}
\hline \multicolumn{2}{|c|}{ Facility Name: CPP-651, Materials and Security Consolidation Facility } \\
\hline Chapter IV, LLW Requirements & Facility Compliance Information \\
\hline $\begin{array}{l}\text { to show that the storage of low-level waste containers is in a } \\
\text { facility or manner where the containers would not be damaged } \\
\text { by normal weather events, and cannot be accessed by } \\
\text { unauthorized personnel. Further, each container can be traced to } \\
\text { its certification and the information supporting that certification. }\end{array}$ & \\
\hline $\begin{array}{l}\text { K. Waste Transfer. A documented process shall be established and } \\
\text { implemented for transferring responsibility for management of low- } \\
\text { level waste and for ensuring availability of relevant data. The } \\
\text { following requirements are in addition to those in Chapter I of this } \\
\text { Manual. }\end{array}$ & $\begin{array}{l}\text { MCP-17000 specifies the requirements for } \\
\text { preparing an IWTS profile that captures } \\
\text { waste certification data, transfer } \\
\text { information, and associated authorizations. } \\
\text { MCP-17500 nrovides the Waste Generator }\end{array}$ \\
\hline $\begin{array}{l}\text { From DOE G 435.1-1 Chapter IV: Compliance with this } \\
\text { requirement is demonstrated if facilities have procedures for the } \\
\text { receipt of waste and the transfer of waste, as appropriate, which } \\
\text { address the acquisition of waste and container data and the transfer } \\
\text { of ownership, respectively. Further evidence of acceptable } \\
\text { performance is facility records showing that data on the waste } \\
\text { containers is available and accurate, and that documented transfer } \\
\text { of responsibility occurs. }\end{array}$ & $\begin{array}{l}\text { Services Waste Certification Program for } \\
\text { LLW to be shipped to NNSS. }\end{array}$ \\
\hline $\begin{array}{l}\text { (1) Authorization. Low-level waste shall not be transferred to a } \\
\text { storage, treatment, or disposal facility until personnel } \\
\text { responsible for the facility receiving the waste authorize the } \\
\text { transfer. }\end{array}$ & See K. above. \\
\hline $\begin{array}{l}\text { From DOE G 435.1-1 Chapter IV: Compliance with this } \\
\text { requirement is demonstrated by sites having procedures that } \\
\text { require a confirmation of authorization before releasing waste } \\
\text { for transfer, and records showing that transfers are made in } \\
\text { accordance with written authorizations. }\end{array}$ & \\
\hline $\begin{array}{l}\text { (2) Data. Waste characterization data, container information, and } \\
\text { generation, storage, treatment, and transportation information } \\
\text { for low-level waste shall be transferred with or be traceable to } \\
\text { the waste. }\end{array}$ & See K. above. \\
\hline $\begin{array}{l}\text { From DOE G 435.1-1 Chapter IV: Compliance with this } \\
\text { requirement is demonstrated if there are procedures requiring } \\
\text { that characterization and container data be provided and } \\
\text { maintained for each low-level waste transfer and documented } \\
\text { records of transfers show that the information is being provided. }\end{array}$ & \\
\hline $\begin{array}{l}\text { L. Packaging and Transportation. The following requirements are in } \\
\text { addition to those in Chapter I of this Manual [DOE M 435.1-1 } \\
\S I .1 . E(11)] \text {. }\end{array}$ & $\begin{array}{l}\text { DOE Manual 435.1-1 } \S \text { I.1.E(11) applies to } \\
\text { field element managers. }\end{array}$ \\
\hline $\begin{array}{l}\text { (1) Packaging. If containers are used: } \\
\text { From DOE G 435.1-1 Chapter IV: Compliance with the } \\
\text { packaging requirement is demonstrated by: (1) procedures } \\
\text { which document proper packaging protocols; and (2) no trends } \\
\text { of routine repackaging of low-level waste that is packaged after } \\
\text { issuance of DOE O } 435.1 \text {. Successful performance of this } \\
\text { requirement is also demonstrated by a record of containers for } \\
\text { which failure has not routinely occurred under management } \\
\text { conditions. It is recognized that there may be failed containers } \\
\text { for waste previously placed in storage. For those containers, the }\end{array}$ & $\begin{array}{l}\text { MCP-17000 } \$ 4 \text { addresses packaging } \\
\text { requirements. }\end{array}$ \\
\hline
\end{tabular}


Table 1. (continued).

\begin{tabular}{|c|c|}
\hline \multicolumn{2}{|c|}{ Facility Name: CPP-651, Materials and Security Consolidation Facility } \\
\hline Chapter IV, LLW Requirements & Facility Compliance Information \\
\hline $\begin{array}{l}\text { goal is to only have to repackage the waste one time after it is } \\
\text { retrieved and characterized. Further, acceptable performance is } \\
\text { demonstrated by containers of waste having marking and } \\
\text { labeling that allows correlation with waste characterization data } \\
\text { and container information. }\end{array}$ & \\
\hline $\begin{array}{l}\text { (a) Low-level waste shall be packaged in a manner that provides } \\
\text { containment and protection for the duration of the } \\
\text { anticipated storage period and until disposal is achieved or } \\
\text { until the waste has been removed from the container. }\end{array}$ & See (1) above. \\
\hline $\begin{array}{l}\text { (b) When waste is packaged, vents or other measures shall be } \\
\text { provided if the potential exists for pressurizing or generating } \\
\text { flammable or explosive concentrations of gases within the } \\
\text { waste container. }\end{array}$ & See (1) above. \\
\hline $\begin{array}{l}\text { (c) Containers of low-level waste shall be marked such that their } \\
\text { contents can be identified. }\end{array}$ & See (1) above. \\
\hline $\begin{array}{l}\text { (2) Transportation. To the extent practical, the volume of waste and } \\
\text { number of low-level waste shipments shall be minimized. } \\
\text { From DOE G 435.1-1 Chapter IV: Compliance with this } \\
\text { requirement can be demonstrated by a combination of site } \\
\text { procedures directing the efficient use of waste container }\end{array}$ & $\begin{array}{l}\text { MCP-17000 } \$ 4 \text { addresses transportation. } \\
\text { The waste disposition specialist coordinates } \\
\text { with packaging and transportation } \\
\text { personnel for waste shipped offsite from } \\
\text { this facility. }\end{array}$ \\
\hline $\begin{array}{l}\text { capacity and documentation showing that low-level waste } \\
\text { shipments are systematically planned and optimized to the } \\
\text { extent practical. }\end{array}$ & $\begin{array}{l}\text { Waste is shipped directly to NNSS from } \\
\text { this facility. MCP-17500 specifies waste } \\
\text { certification official and waste disposition } \\
\text { specialist responsibilities and coordination } \\
\text { with packaging and transportation } \\
\text { personnel. }\end{array}$ \\
\hline $\begin{array}{l}\text { M. Site Evaluation and Facility Design. The following requirements } \\
\text { are in addition to those in Chapter I of this Manual. }\end{array}$ & $\begin{array}{l}\text { NA; this requirement addresses new } \\
\text { radioactive waste management facilities. }\end{array}$ \\
\hline $\begin{array}{l}\text { (1) Site Evaluation. Proposed locations for low-level waste } \\
\text { facilities shall be evaluated to identify relevant features that } \\
\text { should be avoided or must be considered in facility design and } \\
\text { analyses. }\end{array}$ & See M. above. \\
\hline $\begin{array}{l}\text { (a) Each site proposed for a new low-level waste facility or } \\
\text { expansion of an existing low-level waste facility shall be } \\
\text { evaluated considering environmental characteristics, } \\
\text { geotechnical characteristics, and human activities, including } \\
\text { for a low-level waste disposal facility, the capability of the } \\
\text { site to demonstrate, at a minimum, whether it is: }\end{array}$ & See M. above. \\
\hline $\begin{array}{l}1 \text { Located to accommodate the projected volume of waste to } \\
\text { be received; }\end{array}$ & See M. above. \\
\hline $\begin{array}{l}2 \text { Located in a flood plain, a tectonically active area, or in } \\
\text { the zone of water table fluctuation; and }\end{array}$ & See M. above. \\
\hline $\begin{array}{l}3 \text { Located where radionuclide migration pathways are } \\
\text { predictable and erosion and surface runoff can be } \\
\text { controlled. }\end{array}$ & See M. above. \\
\hline $\begin{array}{l}\text { (b) Proposed sites with environmental characteristics, } \\
\text { geotechnical characteristics, and human activities for which } \\
\text { adequate protection cannot be provided through facility }\end{array}$ & See M. above. \\
\hline
\end{tabular}


Table 1. (continued).

\begin{tabular}{|c|c|}
\hline \multicolumn{2}{|c|}{ Facility Name: CPP-651, Materials and Security Consolidation Facility } \\
\hline Chapter IV, LLW Requirements & Facility Compliance Information \\
\hline $\begin{array}{l}\text { design shall be deemed unsuitable for the location of the } \\
\text { facility. }\end{array}$ & \\
\hline $\begin{array}{l}\text { (c) Low-level waste disposal facilities shall be sited to achieve } \\
\text { long-term stability and to minimize, to the extent practical, } \\
\text { the need for active maintenance following final closure. }\end{array}$ & See M. above. \\
\hline $\begin{array}{l}\text { (2) Low-Level Waste Treatment and Storage Facility Design. The } \\
\text { following facility requirements and general design criteria, at a } \\
\text { minimum, apply: }\end{array}$ & See M. above. \\
\hline $\begin{array}{l}\text { (a) Confinement. Low-level waste systems and components } \\
\text { shall be designed to maintain waste confinement. }\end{array}$ & See M. above. \\
\hline (b) Ventilation. & See M. above. \\
\hline $\begin{array}{l}1 \text { Design of low-level waste treatment and storage facilities } \\
\text { shall include ventilation, if applicable, through an } \\
\text { appropriate filtration system to maintain the release of } \\
\text { radioactive material in airborne effluents within the } \\
\text { requirements and guidelines specified in applicable } \\
\text { requirements. }\end{array}$ & See M. above. \\
\hline $\begin{array}{l}2 \text { When conditions exist for generating gases in flammable } \\
\text { or explosive concentrations, ventilation systems or other } \\
\text { measures shall be provided to keep the gases in a non- } \\
\text { flammable and nonexplosive condition. Where } \\
\text { concentrations of explosive or flammable gases are } \\
\text { expected to approach the lower flammability limit, } \\
\text { measures shall be taken to prevent deflagration or } \\
\text { detonation. }\end{array}$ & See M. above. \\
\hline $\begin{array}{l}\text { (c) Consideration of Decontamination and Decommissioning. } \\
\text { Areas in new and modifications to existing low-level waste } \\
\text { management facilities that are subject to contamination with } \\
\text { radioactive or other hazardous materials shall be designed to } \\
\text { facilitate decontamination. For such facilities a proposed } \\
\text { decommissioning method or a conversion method leading to } \\
\text { reuse shall be described. }\end{array}$ & See M. above. \\
\hline $\begin{array}{l}\text { (d) Instrumentation and Control Systems. Engineering controls } \\
\text { shall be incorporated in the design and engineering of low- } \\
\text { level waste treatment and storage facilities to provide } \\
\text { volume inventory data and to prevent spills, leaks, and } \\
\text { overflows from tanks or confinement systems. }\end{array}$ & See M. above. \\
\hline $\begin{array}{l}\text { (e) Monitoring. Monitoring and/or leak detection capabilities } \\
\text { shall be incorporated in the design and engineering of low- } \\
\text { level waste treatment and storage facilities to provide rapid } \\
\text { identification of failed confinement and/or other abnormal } \\
\text { conditions. }\end{array}$ & See M. above. \\
\hline $\begin{array}{l}\text { (3) Low-Level Waste Disposal Facility Design. The following } \\
\text { facility requirements and general design criteria, at a minimum, } \\
\text { apply: }\end{array}$ & See M. above. \\
\hline $\begin{array}{l}\text { (a) Confinement. Low-level waste systems and components } \\
\text { shall be designed to maintain waste confinement. }\end{array}$ & See M. above. \\
\hline (b) Ventilation. & See M. above. \\
\hline
\end{tabular}


Table 1. (continued).

\begin{tabular}{|c|c|}
\hline \multicolumn{2}{|c|}{ Facility Name: CPP-651, Materials and Security Consolidation Facility } \\
\hline Chapter IV, LLW Requirements & \begin{tabular}{|c|} 
Facility Compliance Information \\
\end{tabular} \\
\hline $\begin{array}{l}1 \text { Design of low-level waste disposal facilities shall include } \\
\text { ventilation, if applicable, through an appropriate filtration } \\
\text { system to maintain the release of radioactive material in } \\
\text { airborne effluents within the requirements and guidelines } \\
\text { specified in applicable requirements. }\end{array}$ & See M. above. \\
\hline $\begin{array}{l}2 \text { When conditions exist for generating gases in flammable } \\
\text { or explosive concentrations, ventilation systems or other } \\
\text { measures shall be provided to keep the gases in a non- } \\
\text { flammable and non-explosive condition. Where } \\
\text { concentrations of explosive or flammable gases are } \\
\text { expected to approach the lower flammability limit, } \\
\text { measures shall be taken to prevent deflagration or } \\
\text { detonation. }\end{array}$ & See M. above. \\
\hline $\begin{array}{l}\text { (c) Stability. Low-level waste disposal facilities shall be } \\
\text { designed to achieve long-term stability and to minimize to } \\
\text { the extent practical, the need for active maintenance } \\
\text { following final closure. }\end{array}$ & See M. above. \\
\hline $\begin{array}{l}\text { (d) Control of Water. Low-level waste disposal facilities shall } \\
\text { be designed to minimize to the extent practical, the contact } \\
\text { of waste with water during and after disposal. }\end{array}$ & See M. above. \\
\hline $\begin{array}{l}\text { N. Storage and Staging. The following requirements are in addition to } \\
\text { those in Chapter I of this Manual [DOE M 435.1-1 §I.2.F(13)]. }\end{array}$ & $\begin{array}{l}\text { DOE Manual 435.1-1 §I.2.F(13) applies to } \\
\text { field element managers. }\end{array}$ \\
\hline $\begin{array}{l}\text { (1) Storage Prohibitions. Low-level waste in storage shall not be } \\
\text { readily capable of detonation, explosive decomposition, reaction } \\
\text { at anticipated pressures and temperatures, or explosive reaction } \\
\text { with water. Prior to storage, pyrophoric materials shall be } \\
\text { treated, prepared, and packaged to be nonflammable. }\end{array}$ & NA; this facility does not store LLW. \\
\hline $\begin{array}{l}\text { From DOE G 435.1-1 Chapter IV: Compliance with this } \\
\text { requirement is demonstrated by having waste acceptance } \\
\text { requirements which prohibit low-level waste that is ignitable or } \\
\text { explosive from being accepted for storage unless it has been } \\
\text { treated, and procedures for properly preparing such materials for } \\
\text { safe storage. }\end{array}$ & \\
\hline $\begin{array}{l}\text { (2) Storage Limit. Low-level waste that has an identified path to } \\
\text { disposal shall not be stored longer than one year prior to } \\
\text { disposal, except for storage for decay, or as otherwise } \\
\text { authorized by the Field Element Manager. }\end{array}$ & $\begin{array}{l}\text { NA; this facility does not store LLW. See } \\
\text { N. (7) below for staging requirements. }\end{array}$ \\
\hline $\begin{array}{l}\text { From DOE G } 435.1-1 \text { Chapter IV: Storage longer than one year } \\
\text { can be justified if the conditions for such storage are approved } \\
\text { by the Field Element Manager as part of the radioactive waste } \\
\text { management basis for the facility. }\end{array}$ & \\
\hline $\begin{array}{l}\text { Storage for radioactive decay for a period greater than } 1 \text { year for } \\
\text { waste that has an identified path to disposal is allowed. } \\
\text { Adequate justification and the supporting information for } \\
\text { storage for decay is to be documented in the radioactive waste } \\
\text { management basis for the facility in which the storage will take } \\
\text { place. }\end{array}$ & \\
\hline $\begin{array}{c}\text { (a) Mixed waste. Under the Federal Facility Compliance Act of } \\
1992, \text { DOE sites were required to develop Site Treatment }\end{array}$ & \\
\hline
\end{tabular}


Table 1. (continued).

\begin{tabular}{|c|c|}
\hline \multicolumn{2}{|c|}{ Facility Name: CPP-651, Materials and Security Consolidation Facility } \\
\hline Chapter IV, LLW Requirements & Facility Compliance Information \\
\hline $\begin{array}{l}\text { Plans to bring stored mixed low-level waste into compliance } \\
\text { with these requirements. The Site Treatment Plan needs to } \\
\text { be consulted and any mixed low-level waste stored for the } \\
\text { purpose of accumulation to facilitate treatment must meet } \\
\text { Resource Conservation and Recovery Act storage } \\
\text { requirements. There could be several ways within different } \\
\text { scenarios that this requirement can be met, as illustrated by } \\
\text { the examples below, however, there are basically four ways } \\
\text { to show compliance with the requirement and include } \\
\text { appropriate provisions in the radioactive waste management } \\
\text { basis for the facility in which it is stored. }\end{array}$ & \\
\hline $\begin{array}{l}\text { (b) Legacy waste. As discussed above, the intention of the } \\
\text { requirement is not to force malicious compliance or heroic } \\
\text { actions which would result in increased risk or safety } \\
\text { concerns. Rather, the intention is that waste in storage longer } \\
\text { than one year receives additional attention to ensure that the } \\
\text { public, the workers, and the environment are protected from } \\
\text { the hazards of the waste, and that progress is being made to } \\
\text { dispose of the waste. There could be several ways within } \\
\text { different scenarios that this requirement can be met, as } \\
\text { illustrated by the examples below, however, there are } \\
\text { basically four ways to show compliance with the } \\
\text { requirement: }\end{array}$ & \\
\hline $\begin{array}{l}1 \text { the radioactive waste management basis allows for storage } \\
\text { for no more than one year. }\end{array}$ & \\
\hline $\begin{array}{l}2 \text { the radioactive waste management basis allows for storage } \\
\text { for no more than one year, or for storage for decay only } \\
\text { for periods greater than a year, which are specified on a } \\
\text { radionuclide basis. }\end{array}$ & \\
\hline $\begin{array}{l}3 \text { the radioactive waste management basis allows for storage } \\
\text { for more than one year, up to a specified period of time } \\
\text { based on a documented technical evaluation that the waste } \\
\text { can be stored in a manner that does not cause changes to } \\
\text { the waste or waste packages that is detrimental to the safe } \\
\text { storage of the waste, the final disposal of the waste or to } \\
\text { meeting the disposal performance objectives. }\end{array}$ & \\
\hline $\begin{array}{l}4 \text { the radioactive waste management basis allows for storage } \\
\text { for decay (with specifics) and for storage for more than } \\
\text { one year for other low-level waste, up to a specified period } \\
\text { of time based on a documented technical evaluation that } \\
\text { the waste can be stored in a manner that does not cause } \\
\text { changes to the waste or waste packages that is detrimental } \\
\text { to the safe storage of the waste, the final disposal of the } \\
\text { waste or to meeting the disposal performance objectives. }\end{array}$ & \\
\hline $\begin{array}{l}\text { Compliance with this requirement is demonstrated by the } \\
\text { existence of a radioactive waste management basis for the } \\
\text { storage facility approved by the Field Element Manager } \\
\text { that includes the time frames that waste are allowed to be } \\
\text { stored, the necessary justifications for storage for decay, } \\
\text { and the necessary technical evaluations if storage is to }\end{array}$ & \\
\hline
\end{tabular}


Table 1. (continued).

\begin{tabular}{|c|c|}
\hline \multicolumn{2}{|c|}{ Facility Name: CPP-651, Materials and Security Consolidation Facility } \\
\hline Chapter IV, LLW Requirements & Facility Compliance Information \\
\hline extend significantly beyond the one-year time frame. & \\
\hline $\begin{array}{l}\text { (3) Storage Integrity. Low-level waste shall be stored in a location } \\
\text { and manner that protects the integrity of waste for the expected } \\
\text { time of storage and minimizes worker exposure. }\end{array}$ & $\begin{array}{l}\text { NA; this facility does not store LLW. See } \\
\text { N. (7) below for staging requirements. }\end{array}$ \\
\hline $\begin{array}{l}\text { From DOE G 435.1-1 Chapter IV: However, in making a } \\
\text { decision to use a facility for storage and in developing a } \\
\text { radioactive waste management basis for the activity, particular } \\
\text { attention to protection of workers is needed. }\end{array}$ & \\
\hline $\begin{array}{l}\text { Compliance with this requirement is demonstrated if sites have } \\
\text { storage capabilities for low-level waste that provide protection } \\
\text { to waste containers so that their integrity will not be damaged } \\
\text { through physical or chemical (corrosion) processes and that } \\
\text { keep personnel from spending extended periods of time in the } \\
\text { areas where low-level waste is stored. }\end{array}$ & \\
\hline (4) Waste Characterization for Storage. & $\begin{array}{l}\text { NA; this facility does not store LLW. See } \\
\text { N. (7) below for staging requirements. }\end{array}$ \\
\hline $\begin{array}{l}\text { (a) Low-level waste that does not have an identified path to } \\
\text { disposal shall be characterized as necessary to meet the data } \\
\text { quality objectives and minimum characterization } \\
\text { requirements of this Chapter, to ensure safe storage, and to } \\
\text { facilitate disposal. }\end{array}$ & $\begin{array}{l}\text { NA; this facility does not store LLW. See } \\
\text { N. (7) below for staging requirements. }\end{array}$ \\
\hline $\begin{array}{l}\text { (b) Characterization information for all low-level waste in } \\
\text { storage shall be maintained as a record in accordance with } \\
\text { the requirements for Records Management in Chapter I of } \\
\text { this Manual. }\end{array}$ & $\begin{array}{l}\text { NA; this facility does not store LLW. See } \\
\text { N. (7) below for staging requirements. }\end{array}$ \\
\hline $\begin{array}{l}\text { From DOE G 435.1-1 Chapter IV: Compliance with this } \\
\text { requirement is demonstrated by documented procedures for } \\
\text { managing waste characterization and container information } \\
\text { on low-level waste as a Federal record. The records are } \\
\text { managed per the applicable policies and procedures for } \\
\text { records management referenced in DOE O } 200.1 \text { and } \\
\text { established at the applicable Field Element. }\end{array}$ & \\
\hline $\begin{array}{l}\text { (5) Container Inspection. A process shall be developed and } \\
\text { implemented for inspecting and maintaining containers of low- } \\
\text { level waste to ensure container integrity is not compromised. }\end{array}$ & $\begin{array}{l}\text { LI-435 requires quarterly inspections of } \\
\text { radioactive waste containers if waste is } \\
\text { stored outdoors or has been in storage for }\end{array}$ \\
\hline $\begin{array}{l}\text { From DOE G 435.1-1 Chapter IV: Compliance with this } \\
\text { requirement is demonstrated by: (1) a documented process for } \\
\text { waste container inspection and maintenance; and (2) } \\
\text { documentation for all waste container inspections and } \\
\text { maintenance actions performed. }\end{array}$ & greater than 1 year. \\
\hline $\begin{array}{l}\text { (6) Storage Management. Low-level waste storage shall be } \\
\text { managed to identify and segregate low-level waste from mixed } \\
\text { low-level waste. }\end{array}$ & $\begin{array}{l}\text { NA; this facility does not store LLW. See } \\
\text { N. (7) below for staging requirements. }\end{array}$ \\
\hline $\begin{array}{l}\text { (7) Staging. Staging of low-level waste shall be for the purpose of } \\
\text { the accumulation of such quantities of waste as necessary to } \\
\text { facilitate transportation, treatment, and disposal. Staging longer } \\
\text { than } 90 \text { days shall meet the requirements for storage above and } \\
\text { in Chapter I of this Manual. } \\
\text { From DOE G 435.1-1 Chapter IV: The staging of low-level }\end{array}$ & $\begin{array}{l}\text { Routine LLW, such as personal protective } \\
\text { equipment, is accumulated at this facility } \\
\text { for disposal. MCP-17000, Appendix F, } \\
\text { "Container Start Date and Storage } \\
\text { Prohibitions," restricts staging LLW to } \\
90 \text { days maximum at any generator or }\end{array}$ \\
\hline
\end{tabular}


Table 1. (continued).

\begin{tabular}{|c|c|}
\hline \multicolumn{2}{|c|}{ Facility Name: CPP-651, Materials and Security Consolidation Facility } \\
\hline Chapter IV, LLW Requirements & Facility Compliance Information \\
\hline $\begin{array}{l}\text { waste needs to be addressed in the radioactive waste } \\
\text { management basis for the facility that is performing the staging. } \\
\text { Generators, treatment facilities, and disposal facilities that stage } \\
\text { waste must ensure that the action of staging is included and } \\
\text { authorized as part of their radioactive waste management basis } \\
\text { for the affected facilities, operations, or activities. } \\
\text { Staging longer than } 90 \text { days must be justified, the conditions for } \\
\text { such storage met, and these practices approved by the Field } \\
\text { Element Manager as part of the radioactive waste management } \\
\text { basis for the facility. } \\
\text { Compliance with this requirement is demonstrated by a staging } \\
\text { program that limits the temporary storage of waste to only } \\
\text { circumstances allowed in the requirement, including } \\
\text { justifications for any staging that exceeds the } 90 \text {-day period, } \\
\text { which is documented in the radioactive waste management basis } \\
\text { for the facility. }\end{array}$ & $\begin{array}{l}\text { treatment facility prior to acceptance by a } \\
\text { storage facility. } \\
\text { As stated in DOE Guide } 435.1-1 \S \mathrm{IV} . \mathrm{N} .(7), \\
\text { staging waste in accordance with this } \\
\text { requirement allows waste to be } \\
\text { accumulated without being considered } \\
\text { storage and being bound by the associated } \\
\text { storage requirements. }\end{array}$ \\
\hline $\begin{array}{l}\text { O. Treatment. Low-level waste treatment to provide more stable waste } \\
\text { forms and to improve the long-term performance of a low-level } \\
\text { waste disposal facility shall be implemented as necessary to meet } \\
\text { the performance objectives of the disposal facility. } \\
\text { From DOE G } 435.1-1 \text { Chapter IV: Compliance with this } \\
\text { requirement is demonstrated when a treatment facility or process } \\
\text { ensures that treated waste will meet the minimum waste form } \\
\text { requirements of DOE M } 435.1 \text { and meet additional disposal } \\
\text { facility-specific waste acceptance requirements for additional } \\
\text { stability or long-term performance of facilities that will receive the } \\
\text { treated waste. }\end{array}$ & NA; this facility does not treat LLW. \\
\hline $\begin{array}{l}\text { P. Disposal. Low-level waste disposal facilities shall meet the } \\
\text { following requirements. }\end{array}$ & NA; this facility does not dispose of LLW. \\
\hline $\begin{array}{l}\text { (1) Performance Objectives. Low-level waste disposal facilities } \\
\text { shall be sited, designed, operated, maintained, and closed so that } \\
\text { a reasonable expectation exists that the following performance } \\
\text { objectives will be met for waste disposed of after September } 26 \text {, } \\
\text { 1988: }\end{array}$ & See P. above. \\
\hline $\begin{array}{l}\text { (a) Dose to representative members of the public shall not } \\
\text { exceed } 25 \text { mrem }(0.25 \mathrm{mSv}) \text { in a year total effective dose } \\
\text { equivalent from all exposure pathways, excluding the dose } \\
\text { from radon and its progeny in air. }\end{array}$ & See P. above. \\
\hline $\begin{array}{l}\text { (b) Dose to representative members of the public via the air } \\
\text { pathway shall not exceed } 10 \mathrm{mrem}(0.10 \mathrm{mSv}) \text { in a year total } \\
\text { effective dose equivalent, excluding the dose from radon and } \\
\text { its progeny. }\end{array}$ & See P. above. \\
\hline $\begin{array}{l}\text { (c) Release of radon shall be less than an average flux of } 20 \\
\mathrm{pCi} / \mathrm{m}^{2} / \mathrm{s}\left(0.74 \mathrm{~Bq} / \mathrm{m}^{2} / \mathrm{s}\right) \text { at the surface of the disposal facility. } \\
\text { Alternatively, a limit of } 0.5 \mathrm{pCi} / 1(0.0185 \mathrm{~Bq} / \mathrm{l}) \text { of air may be } \\
\text { applied at the boundary of the facility. }\end{array}$ & See P. above. \\
\hline $\begin{array}{l}\text { (2) Performance Assessment. A site-specific radiological } \\
\text { performance assessment shall be prepared and maintained for } \\
\text { DOE low-level waste disposed of after September } 26,1988 \text {. The }\end{array}$ & See P. above. \\
\hline
\end{tabular}


Table 1. (continued).

\begin{tabular}{|c|c|}
\hline \multicolumn{2}{|c|}{ Facility Name: CPP-651, Materials and Security Consolidation Facility } \\
\hline Chapter IV, LLW Requirements & Facility Compliance Information \\
\hline $\begin{array}{l}\text { performance assessment shall include calculations for a } 1,000 \\
\text { year period after closure of potential doses to representative } \\
\text { future members of the public and potential releases from the } \\
\text { facility to provide a reasonable expectation that the performance } \\
\text { objectives identified in this Chapter are not exceeded as a result } \\
\text { of operation and closure of the facility. }\end{array}$ & \\
\hline $\begin{array}{l}\text { (a) Analyses performed to demonstrate compliance with the } \\
\text { performance objectives in this Chapter, and to establish } \\
\text { limits on concentrations of radionuclides for disposal based } \\
\text { on the performance measures for inadvertent intruders in this } \\
\text { Chapter shall be based on reasonable activities in the critical } \\
\text { group of exposed individuals. Unless otherwise specified, } \\
\text { the assumption of average living habits and exposure } \\
\text { conditions in representative critical groups of individuals } \\
\text { projected to receive the highest doses is appropriate. The } \\
\text { likelihood of inadvertent intruder scenarios may be } \\
\text { considered in interpreting the results of the analyses and } \\
\text { establishing radionuclide concentrations, if adequate } \\
\text { justification is provided. }\end{array}$ & See P. above. \\
\hline $\begin{array}{l}\text { (b) The point of compliance shall correspond to the point of } \\
\text { highest projected dose or concentration beyond a } 100 \text { meter } \\
\text { buffer zone surrounding the disposed waste. A larger or } \\
\text { smaller buffer zone may be used if adequate justification is } \\
\text { provided. }\end{array}$ & See P. above. \\
\hline $\begin{array}{l}\text { (c) Performance assessments shall address reasonably } \\
\text { foreseeable natural processes that might disrupt barriers } \\
\text { against release and transport of radioactive materials. }\end{array}$ & See P. above. \\
\hline $\begin{array}{l}\text { (d) Performance assessments shall use DOE-approved dose } \\
\text { coefficients (dose conversion factors) for internal and } \\
\text { external exposure of reference adults. }\end{array}$ & See P. above. \\
\hline $\begin{array}{l}\text { (e) The performance assessment shall include a } \\
\text { sensitivity/uncertainty analysis. }\end{array}$ & See P. above. \\
\hline $\begin{array}{l}\text { (f) Performance assessments shall include a demonstration that } \\
\text { projected releases of radionuclides to the environment shall } \\
\text { be maintained as low as reasonably achievable (ALARA). }\end{array}$ & See P. above. \\
\hline $\begin{array}{l}\text { (g) For purposes of establishing limits on radionuclides that may } \\
\text { be disposed of near-surface, the performance assessment } \\
\text { shall include an assessment of impacts to water resources. }\end{array}$ & See P. above. \\
\hline $\begin{array}{l}\text { (h) For purposes of establishing limits on the concentration of } \\
\text { radionuclides that may be disposed of near-surface, the } \\
\text { performance assessment shall include an assessment of } \\
\text { impacts calculated for a hypothetical person assumed to } \\
\text { inadvertently intrude for a temporary period into the low- } \\
\text { level waste disposal facility. For intruder analyses, } \\
\text { institutional controls shall be assumed to be effective in } \\
\text { deterring intrusion for at least } 100 \text { years following closure. } \\
\text { The intruder analyses shall use performance measures for } \\
\text { chronic and acute exposure scenarios, respectively, of } 100 \\
\text { mrem }(1 \mathrm{mSv}) \text { in a year and } 500 \text { mrem }(5 \mathrm{mSv}) \text { total } \\
\text { effective dose equivalent excluding radon in air. }\end{array}$ & See P. above. \\
\hline
\end{tabular}


Table 1. (continued).

\begin{tabular}{|c|c|}
\hline \multicolumn{2}{|c|}{ Facility Name: CPP-651, Materials and Security Consolidation Facility } \\
\hline Chapter IV, LLW Requirements & Facility Compliance Information \\
\hline $\begin{array}{l}\text { (3) Composite Analysis. For disposal facilities which received } \\
\text { waste after September 26, 1988, a site-specific radiological } \\
\text { composite analysis shall be prepared and maintained that } \\
\text { accounts for all sources of radioactive material that may be left } \\
\text { at the DOE site and may interact with the low- level waste } \\
\text { disposal facility, contributing to the dose projected to a } \\
\text { hypothetical member of the public from the existing or future } \\
\text { disposal facilities. Performance measures shall be consistent } \\
\text { with DOE requirements for protection of the public and } \\
\text { environment and evaluated for a } 1,000 \text { year period following } \\
\text { disposal facility closure. The composite analysis results shall be } \\
\text { used for planning, radiation protection activities, and future use } \\
\text { commitments to minimize the likelihood that current low- level } \\
\text { waste disposal activities will result in the need for future } \\
\text { corrective or remedial actions to adequately protect the public } \\
\text { and the environment. }\end{array}$ & See P. above. \\
\hline $\begin{array}{l}\text { (4) Performance Assessment and Composite Analysis Maintenance. } \\
\text { The performance assessment and composite analysis shall be } \\
\text { maintained to evaluate changes that could affect the } \\
\text { performance, design, and operating bases for the facility. } \\
\text { Performance assessment and composite analysis maintenance } \\
\text { shall include the conduct of research, field studies, and } \\
\text { monitoring needed to address uncertainties or gaps in existing } \\
\text { data. The performance assessment shall be updated to support } \\
\text { the final facility closure. Additional iterations of the } \\
\text { performance assessment and composite analysis shall be } \\
\text { conducted as necessary during the post-closure period. }\end{array}$ & See P. above. \\
\hline $\begin{array}{l}\text { (a) Performance assessments and composite analyses shall be } \\
\text { reviewed and revised when changes in waste forms or } \\
\text { containers, radionuclide inventories, facility design and } \\
\text { operations, closure concepts, or the improved understanding } \\
\text { of the performance of the waste disposal facility in } \\
\text { combination with the features of the site on which it is } \\
\text { located alter the conclusions or the conceptual model(s) of } \\
\text { the existing performance assessment or composite analysis. }\end{array}$ & See P. above. \\
\hline $\begin{array}{l}\text { (b) A determination of the continued adequacy of the } \\
\text { performance assessment and composite analysis shall be } \\
\text { made on an annual basis, and shall consider the results of } \\
\text { data collection and analysis from research, field studies, and } \\
\text { monitoring. }\end{array}$ & See P. above. \\
\hline $\begin{array}{l}\text { (c) Annual summaries of low-level waste disposal operations } \\
\text { shall be prepared with respect to the conclusions and } \\
\text { recommendations of the performance assessment and } \\
\text { composite analysis and a determination of the need to revise } \\
\text { the performance assessment or composite analysis. }\end{array}$ & See P. above. \\
\hline $\begin{array}{l}\text { (5) Disposal Authorization. A disposal authorization statement shall } \\
\text { be obtained prior to construction of a new low-level waste } \\
\text { disposal facility. Field Elements with existing low-level waste } \\
\text { disposal facilities shall obtain a disposal authorization statement } \\
\text { in accordance with the schedule in the Complex-Wide Low- }\end{array}$ & See P. above. \\
\hline
\end{tabular}


Table 1. (continued).

\begin{tabular}{|c|c|}
\hline \multicolumn{2}{|c|}{ Facility Name: CPP-651, Materials and Security Consolidation Facility } \\
\hline Chapter IV, LLW Requirements & Facility Compliance Information \\
\hline $\begin{array}{l}\text { Level Waste Management Program Plan. The disposal } \\
\text { authorization statement shall be issued based on a review of the } \\
\text { facility's performance assessment, composite analysis, } \\
\text { performance assessment and composite analysis maintenance, } \\
\text { preliminary closure plan, and preliminary monitoring plan. The } \\
\text { disposal authorization statement shall specify the limits and } \\
\text { conditions on construction, design, operations, and closure of } \\
\text { the low-level waste facility based on these reviews. A disposal } \\
\text { authorization statement is a part of the radioactive waste } \\
\text { management basis for a disposal facility. Failure to obtain a } \\
\text { disposal authorization statement by the implementation date of } \\
\text { this Order shall result in shutdown of the disposal facility. }\end{array}$ & \\
\hline $\begin{array}{l}\text { (6) Disposal Facility Operations. The disposal facility design and } \\
\text { operation must be consistent with the disposal facility closure } \\
\text { plan and lead to disposal facility closure that provides a } \\
\text { reasonable expectation that performance objectives will be met. } \\
\text { Low-level waste shall be disposed in such a manner that } \\
\text { achieves the performance objectives stated in this Chapter, } \\
\text { consistent with the disposal facility radiological performance } \\
\text { assessment. Additional requirements include: }\end{array}$ & See P. above. \\
\hline $\begin{array}{l}\text { (a) Operating procedures shall be developed and implemented } \\
\text { for low-level waste disposal facilities that protect the public, } \\
\text { workers, and the environment; ensure the security of the } \\
\text { facility; minimize subsidence during and after waste } \\
\text { emplacement; achieve long-term stability and minimize the } \\
\text { need for long-term active maintenance; and meet the } \\
\text { requirements of the closure/post-closure plan. }\end{array}$ & See P. above. \\
\hline $\begin{array}{l}\text { (b) Permanent identification markers for disposal excavations } \\
\text { and monitoring wells shall be emplaced. }\end{array}$ & See P. above. \\
\hline $\begin{array}{l}\text { (c) Low-level waste placement into disposal units shall } \\
\text { minimize voids between waste containers. Voids within } \\
\text { disposal units shall be filled to the extent practical. } \\
\text { Uncontainerized bulk waste shall also be placed in a manner } \\
\text { that minimizes voids and subsidence. }\end{array}$ & See P. above. \\
\hline $\begin{array}{l}\text { (d) Operations are to be conducted so that active waste disposal } \\
\text { operations will not have an adverse effect on any other } \\
\text { disposal units. }\end{array}$ & See P. above. \\
\hline $\begin{array}{l}\text { (e) Operations shall include a process for tracking and } \\
\text { documenting low-level waste placement in the facility by } \\
\text { generator source. }\end{array}$ & See P. above. \\
\hline $\begin{array}{l}\text { (7) Alternate Requirements for Low-Level Waste Disposal Facility } \\
\text { Design and Operation. Requirements other than those set forth } \\
\text { in this Section for the design and operation of a low-level waste } \\
\text { disposal facility may be approved on a specific basis if a } \\
\text { reasonable expectation is demonstrated that the disposal } \\
\text { performance objectives will be met. }\end{array}$ & See P. above. \\
\hline $\begin{array}{l}\text { Q. Closure. The following requirements are in addition to those in } \\
\text { Chapter I of this Manual. }\end{array}$ & NA; this facility does not dispose of LLW. \\
\hline (1) Disposal Facility Closure Plans. A preliminary closure plan & See Q. above. \\
\hline
\end{tabular}


Table 1. (continued).

\begin{tabular}{|c|c|}
\hline \multicolumn{2}{|c|}{ Facility Name: CPP-651, Materials and Security Consolidation Facility } \\
\hline Chapter IV, LLW Requirements & Facility Compliance Information \\
\hline $\begin{array}{l}\text { shall be developed and submitted to Headquarters for review } \\
\text { with the performance assessment and composite analysis. The } \\
\text { closure plan shall be updated following issuance of the disposal } \\
\text { authorization statement to incorporate conditions specified in } \\
\text { the disposal authorization statement. Closure plans shall: }\end{array}$ & \\
\hline $\begin{array}{l}\text { (a) Be updated as required during the operational life of the } \\
\text { facility. }\end{array}$ & See Q. above. \\
\hline $\begin{array}{l}\text { (b) Include a description of how the disposal facility will be } \\
\text { closed to achieve long-term stability and minimize the need } \\
\text { for active maintenance following closure and to ensure } \\
\text { compliance with the requirements of DOE 5400.5, Radiation } \\
\text { Protection of the Public and the Environment. }\end{array}$ & See Q. above. \\
\hline $\begin{array}{l}\text { (c) Include the total expected inventory of wastes to be disposed } \\
\text { of at the facility over the operational life of the facility. }\end{array}$ & See Q. above. \\
\hline $\begin{array}{l}\text { (2) Disposal Facility Closure. Closure of a disposal facility shall } \\
\text { occur within a five-year period after it is filled to capacity, or } \\
\text { after the facility is otherwise determined to be no longer needed. }\end{array}$ & See Q. above. \\
\hline $\begin{array}{l}\text { (a) Prior to facility closure, the final inventory of the low-level } \\
\text { waste disposed in the facility shall be prepared and } \\
\text { incorporated in the performance assessment and composite } \\
\text { analysis which shall be updated to support the closure of the } \\
\text { facility. }\end{array}$ & See Q. above. \\
\hline $\begin{array}{l}\text { (b) A final closure plan shall be prepared based on the final } \\
\text { inventory of waste disposed in the facility, the plan } \\
\text { implemented, and the updated performance assessment and } \\
\text { composite analysis prepared in support of the facility } \\
\text { closure. }\end{array}$ & See Q. above. \\
\hline $\begin{array}{l}\text { (c) Institutional control measures shall be integrated into land } \\
\text { use and stewardship plans and programs, and shall continue } \\
\text { until the facility can be released pursuant to DOE 5400.5, } \\
\text { Radiation Protection of the Public and the Environment. }\end{array}$ & See Q. above. \\
\hline $\begin{array}{l}\text { (d) The location and use of the facility shall be filed with the } \\
\text { local authorities responsible for land use and zoning. }\end{array}$ & See Q. above. \\
\hline $\begin{array}{l}\text { R. Monitoring. The following requirements are in addition to those in } \\
\text { Chapter I of this Manual [DOE M 435.1-1 §I.1.E(7)]. }\end{array}$ & $\begin{array}{l}\text { DOE Manual 435.1-1 §I.1.E(7) applies to } \\
\text { field element managers. }\end{array}$ \\
\hline $\begin{array}{l}\text { (1) All Waste Facilities. Parameters that shall be sampled or } \\
\text { monitored, at a minimum, include: temperature, pressure (for } \\
\text { closed systems), radioactivity in ventilation exhaust and liquid } \\
\text { effluent streams, and flammable or explosive mixtures of gases. } \\
\text { Facility monitoring programs shall include verification that } \\
\text { passive and active control systems have not failed. } \\
\text { From DOE G 435.1-1 Chapter IV: The minimum parameters }\end{array}$ & $\begin{array}{l}\text { Monitoring requirements at INL } \\
\text { radioactive waste management facilities are } \\
\text { tailored for the specific facility to enable } \\
\text { timely indication of developing problems. } \\
\text { Existing radiological control procedures } \\
\text { and assessments are followed/completed to } \\
\text { monitor waste facilities. }\end{array}$ \\
\hline $\begin{array}{l}\text { specified in the requirement were selected based on their } \\
\text { potential significance for anticipating and identifying } \\
\text { undesirable conditions at low-level waste management facilities. } \\
\text { Each facility's radioactive waste management basis should } \\
\text { include an evaluation of the applicability and significance of the } \\
\text { minimum parameters. This evaluation also needs to consider } \\
\text { additional parameters to be sampled or monitored to ensure the }\end{array}$ & $\begin{array}{l}\text { LRD-15001 and MCP-139 specify methods } \\
\text { and frequency of radiological control } \\
\text { surveys of all radiological areas. MCP-139 } \\
\text { specifies the use of Form } 441 \text {.A34. This } \\
\text { form is referred to as the "routine sheet" } \\
\text { and is to be used by facility radiological } \\
\text { control foremen to list radiological areas }\end{array}$ \\
\hline
\end{tabular}


Table 1. (continued).

\begin{tabular}{|c|c|}
\hline \multicolumn{2}{|c|}{ Facility Name: CPP-651, Materials and Security Consolidation Facility } \\
\hline Chapter IV, LLW Requirements & Facility Compliance Information \\
\hline $\begin{array}{l}\text { protection of the public health, the environment, and the } \\
\text { workers. If a minimum parameter specified in the requirement is } \\
\text { deemed to be not applicable in any way to the active operation } \\
\text { of that facility, then that justification should be included in the } \\
\text { radioactive waste management basis and when approved } \\
\text { constitutes an exemption to the manual. }\end{array}$ & $\begin{array}{l}\text { that are to be surveyed, the survey periods, } \\
\text { and methods. }\end{array}$ \\
\hline $\begin{array}{l}\text { Verification activities are part of the radioactive waste } \\
\text { management basis as a condition for operation and documented } \\
\text { appropriately. }\end{array}$ & \\
\hline $\begin{array}{l}\text { Compliance with this requirement is demonstrated if monitoring } \\
\text { or sampling for the stated parameters is performed for all } \\
\text { facilities with a precision, accuracy, and frequency consistent } \\
\text { with timely identification of developing problems and a } \\
\text { justification exists in the approved radioactive waste } \\
\text { management basis for those specified parameters which are not } \\
\text { monitored or sampled. }\end{array}$ & \\
\hline $\begin{array}{l}\text { (2) Liquid Waste Storage Facilities. For facilities storing liquid } \\
\text { low-level waste, the following shall also be monitored: liquid } \\
\text { level and/or waste volume, and significant waste chemistry } \\
\text { parameters. }\end{array}$ & $\begin{array}{l}\text { NA; liquid LLW is not stored in this } \\
\text { facility. }\end{array}$ \\
\hline $\begin{array}{l}\text { (3) Disposal Facilities. A preliminary monitoring plan for a low- } \\
\text { level waste disposal facility shall be prepared and submitted to } \\
\text { Headquarters for review with the performance assessment and } \\
\text { composite analysis. The monitoring plan shall be updated within } \\
\text { one year following issuance of the disposal authorization } \\
\text { statement to incorporate and implement conditions specified in } \\
\text { the disposal authorization statement. }\end{array}$ & NA; this facility does not dispose of LLW. \\
\hline $\begin{array}{l}\text { (a) The site-specific performance assessment and composite } \\
\text { analysis shall be used to determine the media, locations, } \\
\text { radionuclides, and other substances to be monitored. }\end{array}$ & See (3) above. \\
\hline $\begin{array}{l}\text { (b) The environmental monitoring program shall be designed to } \\
\text { include measuring and evaluating releases, migration of } \\
\text { radionuclides, disposal unit subsidence, and changes in } \\
\text { disposal facility and disposal site parameters which may } \\
\text { affect long-term performance. }\end{array}$ & See (3) above. \\
\hline $\begin{array}{l}\text { (c) The environmental monitoring programs shall be capable of } \\
\text { detecting changing trends in performance to allow } \\
\text { application of any necessary corrective action prior to } \\
\text { exceeding the performance objectives in this Chapter. }\end{array}$ & See (3) above. \\
\hline
\end{tabular}




\subsection{CPP-653, Cold Waste Handling Facility}

1. Facility description: Built in 1977, CPP-653 is a one-story, reinforced concrete structure located inside the west side of the Idaho Nuclear Technology and Engineering Center (INTEC) security area, east of the west entry guardhouse. A metal extension was added to the facility in 1996. The original

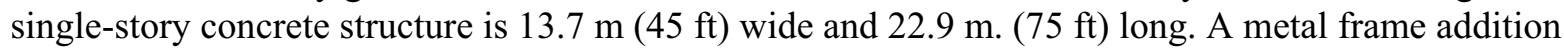
on the east end of the facility is $12.2 \mathrm{~m}$ (40 ft) long. The facility has three large overhead doors: one at the east and two at the west end of the facility. Personnel doors are provided in the northeast, southeast, and southwest comers of the facility. Access to the facility is through an adjoining office (CPP-609) to the southwest door. The facility also contains an office area along the north wall. A freestanding concrete wall remains in the facility from previous uses, but this wall has no function for the current activities.

Former CPP-653 facility operations included paper pellet manufacturing for an onsite coal-fired plant, use as a vehicle monitoring facility, and sampling, characterization, and repackaging of waste for shipment to either onsite or offsite treatment, storage, or disposal facilities. A variety of waste types were handled in the facility, including industrial chemicals, recyclables, hazardous waste, contact-handled (CH) LLW and CH mixed waste, including lead. Waste preparation activities performed included radiation surveys, sampling for chemical analysis, sorting, addition of absorbents, and repackaging.

Planned activities at CPP-653 include radiological dispersion device decontamination testing, where researchers test various technologies to be used to clean up after an urban radiological dispersion device event. Processes will use radionuclides such as Cs-137, Co-60, and Sr-90 in micro-curie amounts. Additional radionuclides also may be used. The contamination may be dispersed on coupons either by aqueous spray or by solid media onto the solid surfaces to be decontaminated and is performed within a tent, hood, or other approved containment device. Decontamination may be performed by abrasion, chemical stripping, water blasting, or other decontamination technologies. All decontamination waste will be collected for proper disposal.

This hazard categorization document does not preclude use of CPP-653 as a multiple use facility for various INL programs. All activities performed within the facility must be performed within the bounds of this document.

2. Hazard category: Less Than Hazard Category 3 radiological

3. Radioactive waste management activities at this facility: Routine CH LLW and solid and liquid process water that has been solidified to support packaging and transportation for shipment-aquaset is staged at this facility.

\section{RWMB documents/programs:}

a) Safety basis/hazards analysis:

- ECAR-1000, "Hazard Categorization for CPP-653 at the Material Security And Consolidation Complex"

b) Laboratory-wide:

- Form 435.39, "Waste Determination and Disposition Form (WDDF)"

- Form 435.42, "Radioactive Waste Inventory Sheet"

- Form 441.A34, "INL Radiological Control Required Surveys"

- LI-435, "Waste Management Routine Field Activities"

- LRD-15001, "Radiological Control Manual"

- LWP-8000, "Environmental Instructions for Facilities, Processes, Materials and Equipment" 
- LWP-13840, "Management of Issues, Observations, and Noteworthy Practices"

- LWP-14002, "Timeout and Stop Work Authority"

- LWP-15011, "Radioactive Material Areas and Radioactive Storage Areas"

- LWP-17000, "Waste Management"

- MCP-139, "Radiological Surveys"

- MCP-17000, "Waste Generator Services Waste Management"

- MCP-17500, "Waste Generator Services Certification of Waste Shipments to the Nevada Test Site"

- PLN-114, "INL Emergency Plan/RCRA Contingency Plan”

- PLN-522, "Quality Assurance Program Plan for the Waste Management/Waste Certification Program"

c) Facility-specific:

- IAG-514, "INL Authorization Agreement for Understanding Between Battelle Energy Alliance (BEA) and CH2M-WGI (CWI) for the Turnover and Operation of CPP-609, CPP-651, CPP-653, CPP-661, CPP-1634, and CPP-1674"

- LI-419, "RDD Decontamination Tests."

LLW is managed at this facility. Table 2 presents the facility compliance information for Chapter IV, "Low-Level Waste Requirements."

Table 2. CPP-653, Cold Waste Handling Facility, DOE Manual 435.1-1 low-level waste requirements and facility compliance information.

\begin{tabular}{|c|c|}
\hline \multicolumn{2}{|c|}{ Facility Name: CPP-653, Cold Waste Handling Facility } \\
\hline Chapter IV, LLW Requirements & Facility Compliance Information \\
\hline $\begin{array}{l}\text { A. Definition of Low-Level Waste. Low-level radioactive waste is } \\
\text { radioactive waste that is not high-level radioactive waste, spent } \\
\text { nuclear fuel, transuranic waste, byproduct material (as defined in } \\
\text { section 11e.(2) of the Atomic Energy Act of 1954, as amended), or } \\
\text { naturally occurring radioactive material. } \\
\text { (From DOE G } 435.1-1 \text { Chapter IV: Low-level radioactive waste is } \\
\text { defined by what it is not. The guidance on definitions in Chapters II } \\
\text { and III should be consulted first for making a determination on how } \\
\text { to properly manage a suspect waste stream.) }\end{array}$ & $\begin{array}{l}\text { This requirement provides the criteria for } \\
\text { determining which DOE radioactive waste } \\
\text { is to be managed as LLW in accordance } \\
\text { with DOE Manual 435.1-1, Chapter IV. } \\
\text { Radioactive waste managed at this facility } \\
\text { under the requirements of this chapter is } \\
\text { not managed under the requirements of } \\
\text { DOE Manual 435.1-1 Chapter II or } \\
\text { Chapter III. }\end{array}$ \\
\hline $\begin{array}{l}\text { B. Management of Specific Wastes. The following provide for } \\
\text { management of specific wastes as low-level waste in accordance } \\
\text { with the requirements in this Chapter: }\end{array}$ & See (1), (2), (3), and (4) below. \\
\hline $\begin{array}{l}\text { (1) Mixed Low-Level Waste. Low-level waste determined to contain } \\
\text { both source, special nuclear, or byproduct material subject to the } \\
\text { Atomic Energy Act of 1954, as amended, and a hazardous } \\
\text { component subject to the Resource Conservation and Recovery } \\
\text { Act (RCRA), as amended, shall be managed in accordance with } \\
\text { the requirements of RCRA and DOE O 435.1, Radioactive Waste } \\
\text { Management, and this Manual. }\end{array}$ & $\begin{array}{l}\text { NA; this facility does not manage } \\
\text { RCRA-regulated mixed LLW. }\end{array}$ \\
\hline $\begin{array}{l}\text { (2) TSCA-Regulated Waste. Low-level waste containing } \\
\text { polychlorinated biphenyls, asbestos, or other such regulated toxic } \\
\text { components shall be managed in accordance with requirements } \\
\text { derived from the Toxic Substances Control Act, as amended, } \\
\text { DOE O 435.1, Radioactive Waste Management, and this Manual. }\end{array}$ & $\begin{array}{l}\text { NA; this facility does not manage } \\
\text { TSCA-regulated waste. }\end{array}$ \\
\hline (3) Accelerator-Produced Waste. Radioactive waste produced as a & NA; this facility does not manage \\
\hline
\end{tabular}


Table 2. (continued).

\begin{tabular}{|c|c|}
\hline \multicolumn{2}{|c|}{ Facility Name: CPP-653, Cold Waste Handling Facility } \\
\hline Chapter IV, LLW Requirements & Facility Compliance Information \\
\hline $\begin{array}{l}\text { result of operations of DOE accelerators is low-level waste and } \\
\text { shall be managed in accordance with DOE O } 435.1 \text {, Radioactive } \\
\text { Waste Management, and this Manual, and all applicable Federal } \\
\text { or State requirements. }\end{array}$ & accelerator-produced waste. \\
\hline $\begin{array}{l}\text { (4) } 11 \text { e.(2) and Naturally Occurring Radioactive Material. Small } \\
\text { quantities of } 11 \mathrm{e} .(2) \text { byproduct material and naturally occurring } \\
\text { radioactive material may be managed as low-level waste } \\
\text { provided they can be managed to meet the requirements for low- } \\
\text { level waste disposal in Section IV.P of this Manual. }\end{array}$ & $\begin{array}{l}\text { NA; this facility does not manage } \\
\text { naturally occurring radioactive material. }\end{array}$ \\
\hline $\begin{array}{l}\text { C. Complex-Wide Low-Level Waste Management Program. A } \\
\text { complex-wide program and plan shall be developed as described } \\
\text { under Responsibilities, 2.B and 2.D, in Chapter I of this Manual. }\end{array}$ & $\begin{array}{l}\text { Not a facility-specific requirement. } \\
\text { DOE Manual 435.1-1 } § I .2 . B \text { and } \S I .2 . D \\
\text { apply to the Assistant Secretary for } \\
\text { Environmental Management and the } \\
\text { Deputy Assistant Secretary for Waste } \\
\text { Management, respectively. }\end{array}$ \\
\hline $\begin{array}{l}\text { D. Radioactive Waste Management Basis. Low-level waste facilities, } \\
\text { operations, and activities shall have a radioactive waste management } \\
\text { basis consisting of physical and administrative controls to ensure the } \\
\text { protection of workers, the public, and the environment. The } \\
\text { following specific waste management controls shall be part of the } \\
\text { radioactive waste management basis: }\end{array}$ & $\begin{array}{l}\text { The RWMB provides the regulatory } \\
\text { framework for management of radioactive } \\
\text { waste at INL. It specifically identifies } \\
\text { facility management and implementing } \\
\text { documents for the generation, storage, } \\
\text { treatment, and disposal of radiological } \\
\text { waste. }\end{array}$ \\
\hline $\begin{array}{l}\text { (1) Generators. The waste certification program. } \\
\text { From DOE G } 435.1-1 \text { Chapter IV: For a facility that generates } \\
\text { low-level waste, the radioactive waste management basis is to } \\
\text { include the program for certifying that waste meets the waste } \\
\text { acceptance requirements of the facility(ies) to which the waste } \\
\text { will be sent. }\end{array}$ & $\begin{array}{l}\text { See J. below for waste certification } \\
\text { program requirements. } \\
\text { ECAR-999 establishes this laboratory } \\
\text { facility as a Less Than Hazard Category } 3 \\
\text { Facility. } \\
\text { LI 1643-11-INTEC is the operating } \\
\text { procedure for these activities. }\end{array}$ \\
\hline $\begin{array}{l}\text { (2) Treatment Facilities. certification program. The waste acceptance } \\
\text { requirements and the waste [sic] } \\
\text { From DOE G 435.1-1 Chapter IV: Facilities that store or treat } \\
\text { low-level waste are to have approved waste acceptance } \\
\text { requirements (see DOE M 435.1-1, Section IV.G) prior to the } \\
\text { issuance of a radioactive waste management basis. } \\
\text { A facility that stores or treats waste also is generally expected to } \\
\text { have a waste certification program. Waste from these facilities } \\
\text { will have to be certified as meeting the waste acceptance } \\
\text { requirements of the facility to which it will be transferred, and } \\
\text { the facilities have the potential for generating radioactive waste } \\
\text { (e.g., secondary processing streams from treatment, monitoring } \\
\text { and sampling, radioactive release cleanup). Consequently, } \\
\text { storage and treatment facilities should also have an approved } \\
\text { waste certification program as part of their radioactive waste } \\
\text { management basis. } \\
\text { As part of the radioactive waste management basis, site personnel } \\
\text { needs to implement a system or process for tracking the waste } \\
\text { inventory at a storage, treatment, or disposal facility. }\end{array}$ & $\begin{array}{l}\text { NA; this facility does not treat LLW. } \\
\text { Containerized elementary neutralization is } \\
\text { performed at this facility as provided by } \\
\text { LWP-8000. As stated in } \$ 4.118, \\
\text { elementary neutralization of corrosive } \\
\text { hazardous waste may take place at any } \\
\text { location where the waste is generated or } \\
\text { stored and neither a generator treatment } \\
\text { plan nor a permit is required. } \\
\text { Solidification of liquid LLW for the } \\
\text { purpose of staging (not for treating the } \\
\text { radioactive constituents) also may be } \\
\text { performed. Therefore, this facility is not } \\
\text { considered to be a treatment facility. }\end{array}$ \\
\hline (3) Storage Facilities. The waste acceptance requirements and the & NA; this facility stages waste in \\
\hline
\end{tabular}


Table 2. (continued).

\section{Facility Name: CPP-653, Cold Waste Handling Facility}

\section{Chapter IV, LLW Requirements}

waste certification program.

From DOE G 435.1-1 Chapter IV: Facilities that store or treat low-level waste are to have approved waste acceptance requirements (see DOE M 435.1-1, Section IV.G) prior to the issuance of a radioactive waste management basis.

A facility that stores or treats waste also is generally expected to have a waste certification program. Waste from these facilities will have to be certified as meeting the waste acceptance requirements of the facility to which it will be transferred, and the facilities have the potential for generating radioactive waste (e.g., secondary processing streams from treatment, monitoring and sampling, radioactive release cleanup). Consequently, storage and treatment facilities should also have an approved waste certification program as part of their radioactive waste management basis.

As part of the radioactive waste management basis, site personnel needs to implement a system or process for tracking the waste inventory at a storage, treatment, or disposal facility.

(4) Disposal Facilities. The performance assessment, composite analysis, disposal authorization statement, closure plan, waste acceptance requirements, and monitoring plan.

E. Contingency Actions. The following requirements are in addition to those in Chapter I of this Manual [DOE M 435.1-1 §I.1.E(5)].

(1) Contingency Storage. For off-normal or emergency situations involving high activity or high hazard liquid low-level waste storage or treatment, spare capacity with adequate capabilities shall be maintained to receive the largest volume of liquid contained in any one storage tank or treatment facility. Tanks or other facilities that are designated low-level waste contingency storage shall be maintained in an operational condition when waste is present and shall meet the requirements of DOE O 435.1, Radioactive Waste Management, and this Manual.

From DOE G 435.1-1 Chapter IV: Compliance with these requirements is demonstrated if adequate spare capacity and transfer equipment exists for emergency transfers of all high activity and high hazard liquid low-level waste. In addition, the capability to perform emergency transfers is demonstrated by having waste transfer routings identified, operational procedures to direct transfers, staff trained to the procedures, and records showing that the spare capacity and transfer capability are kept in operating condition.

(2) Transfer Equipment. Pipelines and auxiliary facilities necessary for the transfer of high activity or high hazard liquid low-level waste to contingency storage shall be maintained in an operational condition when waste is present and shall meet the requirements of DOE O 435.1, Radioactive Waste Management, and this Manual.

From DOE G 435.1-1 Chapter IV: Compliance with these

\section{Facility Compliance Information}

accordance with N.(7) to facilitate

treatment or disposal.
NA; this facility is not a disposal facility.

DOE Manual 435.1-1 §I.1.E(5) addresses the sitewide emergency management system. The INL plan is provided in PLN-114.

NA; this facility does not store liquid LLW.
NA; this facility does not store or treat liquid LLW. 
Table 2. (continued).

Facility Name: CPP-653, Cold Waste Handling Facility

Chapter IV, LLW Requirements

Facility Compliance Information

requirements is demonstrated if adequate spare capacity and transfer equipment exists for emergency transfers of all high activity and high hazard liquid low-level waste. In addition, the capability to perform emergency transfers is demonstrated by having waste transfer routings identified, operational procedures to direct transfers, staff trained to the procedures, and records showing that the spare capacity and transfer capability are kept in operating condition.

F. Corrective Actions. I of this Manual. The following requirements are in addition to those in Chapter [sic]

The INL-wide procedure addressing problem identification as required by From DOE G 435.1-1 Chapter IV: Compliance with DOE M 435.1-1 DOE Manual 435.1-1 §I.2.G.(1) is $\S$ I.2.G.(1) is demonstrated by records showing what corrective actions were taken to remedy situations in the radioactive waste management system.

Compliance with DOE M 435.1-1 §I.2.G.(2) is demonstrated by having the necessary procedures, mechanisms, and training in place to effect shutdown or curtailment of activities which pose an imminent danger or other serious hazard to workers or the public, or are not protective of the environment.

(1) Order Compliance. Corrective actions shall be implemented whenever necessary to ensure the requirements of DOE O 435.1, Radioactive Waste Management, and this Manual are met.

From DOE G 435.1-1 Chapter IV: If a facility or activity can be allowed to operate while a noncompliant or hazardous condition exists, the allowance and any associated limitations must be defined as part of the facility or activity's radioactive waste management basis, identified as a configuration controlled item in a configuration management plan or included in a revision or modification to an operating procedure or similar controlled documentation.

Compliance with this requirement is demonstrated if a corrective action system addresses noncompliant or hazardous situations involving low-level waste management facilities in a systematic fashion, and allows identification of problems by all personnel.

(2) Operations Curtailment. Operations shall be curtailed or facilities The approved RWMB establishes the shut down for failure to establish, maintain, or operate consistent with an approved radioactive waste management basis.

From DOE G 435.1-1 Chapter IV: Compliance with this requirement is demonstrated with a documented system of routine assessments to determine whether waste management activities and facilities are operating in accordance with an approved radioactive waste management basis that provides for graded limitations that can be placed on activities and operations that do not have, or are operating outside of, an approved radioactive waste management basis, including shutdown of the facility.

G. Waste Acceptance. The following requirements are in addition to those in Chapter I of this Manual [DOE M 435.1-1 §I.2.F(6)].

current compliance status at each radioactive waste management facility. Facility assessments are scheduled to ensure waste management activities are conducted in accordance with the approved RWMB.

laboratory's corrective action system.

The INL-wide procedure addressing shutdown or curtailment of activities as required by DOE Manual 435.1-1 §I.2.G.(2) is LWP-14002.

See F. above.

(1) Technical and Administrative. Waste acceptance requirements

DOE Manual 435.1-1 §I.2.F(6) applies to field element managers.

NA; this facility does not accept LLW 
Table 2. (continued).

\begin{tabular}{|c|c|}
\hline \multicolumn{2}{|c|}{ Facility Name: CPP-653, Cold Waste Handling Facility } \\
\hline Chapter IV, LLW Requirements & Facility Compliance Information \\
\hline $\begin{array}{l}\text { for all low-level waste storage, treatment, or disposal facilities, } \\
\text { operations, and activities shall specify, at a minimum, the } \\
\text { following: }\end{array}$ & from other facilities. \\
\hline $\begin{array}{l}\text { From DOE G } 435.1-1 \text { Chapter IV: Compliance with these waste } \\
\text { acceptance requirements is demonstrated if they are documented, } \\
\text { contain clear and precise criteria specifying the radionuclide } \\
\text { limits in the form of contents or concentrations that can be } \\
\text { accepted, the limitations and prohibitions on waste forms and } \\
\text { packages that can be received, and the limits, prohibitions, or } \\
\text { instructions concerning any other technical information so that } \\
\text { the waste is compatible with the safety basis of the facility, and } \\
\text { which will result in acceptable waste at subsequent steps in } \\
\text { managing the low-level waste. }\end{array}$ & \\
\hline $\begin{array}{l}\text { (a) Allowable activities and/or concentrations of specific } \\
\text { radionuclides. }\end{array}$ & See (1) above. \\
\hline $\begin{array}{l}\text { (b) Acceptable waste form and/or container requirements that } \\
\text { ensure the chemical and physical stability of waste under } \\
\text { conditions that might be encountered during transportation, } \\
\text { storage, treatment, or disposal. }\end{array}$ & See (1) above. \\
\hline $\begin{array}{l}\text { (c) Restrictions or prohibitions on waste, materials, or containers } \\
\text { that may adversely affect waste handlers or compromise } \\
\text { facility or waste container performance. }\end{array}$ & See (1) above. \\
\hline $\begin{array}{l}\text { (d) The following are additional waste acceptance requirements } \\
\text { that shall be specified in low-level waste disposal facility } \\
\text { waste acceptance requirements: }\end{array}$ & See (1) above. \\
\hline $\begin{array}{l}1 \text { Low-level waste must contribute to and not detract from } \\
\text { achieving long-term stability of the facility, minimizing the } \\
\text { need for long-term active maintenance, minimizing } \\
\text { subsidence, and minimizing contact of water with waste. } \\
\text { Void spaces within the waste and, if containers are used, } \\
\text { between the waste and its container shall be reduced to the } \\
\text { extent practical. }\end{array}$ & See (1) above. \\
\hline $\begin{array}{l}2 \text { Liquid low-level waste or low-level waste containing free } \\
\text { liquid must be converted into a form that contains as little } \\
\text { freestanding liquid as is reasonably achievable, but in no } \\
\text { case shall the liquid exceed } 1 \text { percent of the waste volume } \\
\text { when the low-level waste is in a disposal container, or } 0.5 \\
\text { percent of the waste volume after it is processed to a stable } \\
\text { form. }\end{array}$ & See (1) above. \\
\hline $\begin{array}{l}3 \text { Low-level waste must not be readily capable of detonation } \\
\text { or of explosive decomposition or reaction at anticipated } \\
\text { pressures and temperatures, or of explosive reaction with } \\
\text { water. Pyrophoric materials contained in waste shall be } \\
\text { treated, prepared, and packaged to be nonflammable. }\end{array}$ & See (1) above. \\
\hline $\begin{array}{l}4 \text { Low-level waste must not contain, or be capable of } \\
\text { generating by radiolysis or biodegradation, quantities of } \\
\text { toxic gases, vapors, or fumes harmful to the public or } \\
\text { workers or disposal facility personnel, or harmful to the } \\
\text { long-term structural stability of the disposal site. }\end{array}$ & See (1) above. \\
\hline
\end{tabular}


Table 2. (continued).

\begin{tabular}{|c|c|}
\hline \multicolumn{2}{|c|}{ Facility Name: CPP-653, Cold Waste Handling Facility } \\
\hline Chapter IV, LLW Requirements & Facility Compliance Information \\
\hline $\begin{array}{l}5 \text { Low-level waste in a gaseous form must be packaged such } \\
\text { that the pressure does not exceed } 1.5 \text { atmospheres absolute } \\
\text { at } 20 \mathrm{C} \text {. [sic] }\end{array}$ & See (1) above. \\
\hline $\begin{array}{l}\text { (e) The basis, procedures, and levels of authority required for } \\
\text { granting exceptions to the waste acceptance requirements, } \\
\text { which shall be contained in each facility's waste acceptance } \\
\text { documentation. Each exception request shall be documented, } \\
\text { including its disposition as approved or not approved. } \\
\text { From DOE G 435.1-1 Chapter IV: Waste acceptance } \\
\text { requirements are acceptable if they are documented and } \\
\text { contain a clear description of the procedure and bases for } \\
\text { obtaining an exception or deviation to the acceptance criteria } \\
\text { for low-level waste to be received at the facility. }\end{array}$ & See (1) above. \\
\hline $\begin{array}{l}\text { (2) Evaluation and Acceptance. The receiving facility shall evaluate } \\
\text { waste for acceptance, including confirmation that the technical } \\
\text { and administrative requirements have been met. A process for the } \\
\text { disposition of non-conforming wastes shall be established. } \\
\text { From DOE G 435.1-1 Chapter IV: Compliance with the waste } \\
\text { acceptance requirements for a low-level waste management } \\
\text { facility is demonstrated if they include a process for evaluation } \\
\text { and acceptance of incoming waste to ensure the acceptance } \\
\text { criteria of the facility receiving the waste are met that includes } \\
\text { one of or a combination of: (1) testing, sampling, and analysis of } \\
\text { representative samples of waste upon receipt; (2) testing, } \\
\text { sampling, and analysis of split samples of waste taken at the } \\
\text { generator site; (3) evaluation of testing, sampling, and analysis of } \\
\text { data provided by the generator, or (4) audits, reviews, } \\
\text { surveillance, or observations of generator waste certification } \\
\text { programs and characterization activities. Additionally, acceptable } \\
\text { waste acceptance requirements for a storage, treatment or } \\
\text { disposal facility will have documented procedures and actions to } \\
\text { be taken if a waste that does not conform to the waste acceptance } \\
\text { criteria is received at the facility. }\end{array}$ & See (1) above. \\
\hline $\begin{array}{l}\text { H. Waste Generation Planning. The following requirements are in } \\
\text { addition to those in Chapter I of this Manual [DOE M 435.1-1 } \\
\text { §I.2.F(7)]. }\end{array}$ & $\begin{array}{l}\text { DOE Manual 435.1-1 §I.2.F(7) applies to } \\
\text { field element managers. }\end{array}$ \\
\hline $\begin{array}{l}\text { (1) Life-Cycle Planning. Prior to waste generation, planning shall be } \\
\text { performed to address the entire life cycle for all low-level waste } \\
\text { streams. } \\
\text { From DOE G 435.1-1 Chapter IV: Compliance with this planning } \\
\text { requirement is demonstrated by the individual sites establishing a } \\
\text { process for evaluating the life-cycle of low-level waste prior to } \\
\text { its generation, including the identification of low-level wastes } \\
\text { with no path to disposal and appropriate records justifying the } \\
\text { newly generated low-level waste stream(s), and site personnel } \\
\text { possessing planning information showing the location(s) where } \\
\text { low-level waste will be stored, treated, and/or disposed along } \\
\text { with a confirmation that the personnel managing the facilities } \\
\text { agree that the low-level waste may be managed at those facilities. }\end{array}$ & $\begin{array}{l}\text { PDD-17000 and LWP- } 17000 \text { provide } \\
\text { direction to the waste generators for waste } \\
\text { generation planning to address the entire } \\
\text { life cycle. } \\
\text { Forms } 435.39 \text { and } 435.42 \text { are used to } \\
\text { identify radioactive LLW. } \\
\end{array}$ \\
\hline
\end{tabular}


Table 2. (continued).

\begin{tabular}{|c|c|}
\hline \multicolumn{2}{|c|}{ Facility Name: CPP-653, Cold Waste Handling Facility } \\
\hline Chapter IV, LLW Requirements & Facility Compliance Information \\
\hline $\begin{array}{l}\text { (2) Waste with No Identified Path to Disposal. Low-level waste } \\
\text { streams with no identified path to disposal shall be generated } \\
\text { only in accordance with approved conditions which, at a } \\
\text { minimum, shall address: }\end{array}$ & $\begin{array}{l}\text { This facility does not generate radioactive } \\
\text { waste that does not have an identified path } \\
\text { to disposal. }\end{array}$ \\
\hline (a) Programmatic need to generate the waste; & See (2) above. \\
\hline $\begin{array}{l}\text { (b) Characteristics and issues preventing the disposal of the } \\
\text { waste; }\end{array}$ & See (2) above. \\
\hline (c) Safe storage of the waste until disposal can be achieved; and & See (2) above. \\
\hline (d) Activities and plans for achieving final disposal of the waste. & See (2) above. \\
\hline $\begin{array}{l}\text { I. Waste Characterization. Low-level waste shall be characterized } \\
\text { using direct or indirect methods, and the characterization } \\
\text { documented in sufficient detail to ensure safe management and } \\
\text { compliance with the waste acceptance requirements of the facility } \\
\text { receiving the waste. } \\
\text { From DOE G 435.1-1 Chapter IV: Compliance with this requirement } \\
\text { is demonstrated by a program for documenting and the existence of } \\
\text { records that document the process for acquiring and verifying the } \\
\text { validity of low-level waste characterization data acquired through } \\
\text { the use of direct or indirect methods. }\end{array}$ & $\begin{array}{l}\text { MCP- } 17000 \S 4 \text { specifies the requirements } \\
\text { for preparing an IWTS profile that } \\
\text { captures waste characterization } \\
\text { information. }\end{array}$ \\
\hline $\begin{array}{l}\text { (1) Data Quality Objectives. The data quality objectives process, or a } \\
\text { comparable process, shall be used for identifying characterization } \\
\text { parameters and acceptable uncertainty in characterization data. } \\
\text { From DOE G } 435.1-1 \text { Chapter IV: Compliance with this } \\
\text { requirement is demonstrated by the documented use of a data } \\
\text { quality objectives or a comparable process for determining the } \\
\text { type, quantity, and quality of characterization data needed to } \\
\text { safely manage low-level waste. }\end{array}$ & $\begin{array}{l}\text { Radioactive waste management facilities } \\
\text { characterize waste in accordance with the } \\
\text { requirements of the receiving storage, } \\
\text { treatment, or disposal facility. The } \\
\text { documented use of a data quality } \\
\text { objectives process, or comparable process, } \\
\text { was not identified for this facility. }\end{array}$ \\
\hline $\begin{array}{l}\text { (2) Minimum Waste Characterization. Characterization data shall, at } \\
\text { a minimum, include the following information relevant to the } \\
\text { management of the waste: } \\
\text { From DOE G } 435.1-1 \text { Chapter IV: Compliance with this } \\
\text { requirement is demonstrated by the existence of a program or } \\
\text { procedure for determining and records that document } \\
\text { characterization of low-level waste consistent with the minimum } \\
\text { characterization data requirements. }\end{array}$ & $\begin{array}{l}\text { MCP- } 17000 \S 4 \text { specifies the requirements } \\
\text { for preparing an IWTS profile that } \\
\text { captures waste characterization } \\
\text { information. }\end{array}$ \\
\hline (a) Physical and chemical characteristics; & See (2) above. \\
\hline $\begin{array}{l}\text { (b) Volume, including the waste and any stabilization or } \\
\text { absorbent media; }\end{array}$ & See (2) above. \\
\hline (c) Weight of the container and contents; & See (2) above. \\
\hline $\begin{array}{l}\text { (d) Identities, activities, and concentrations of major } \\
\text { radionuclides; }\end{array}$ & See (2) above. \\
\hline (e) Characterization date; & See (2) above. \\
\hline (f) Generating source; and & See (2) above. \\
\hline $\begin{array}{l}\text { (g) Any other information which may be needed to prepare and } \\
\text { maintain the disposal facility performance assessment, or } \\
\text { demonstrate compliance with applicable performance } \\
\text { objectives. }\end{array}$ & See (2) above. \\
\hline
\end{tabular}


Table 2. (continued).

\begin{tabular}{|c|c|}
\hline \multicolumn{2}{|c|}{ Facility Name: CPP-653, Cold Waste Handling Facility } \\
\hline Chapter IV, LLW Requirements & Facility Compliance Information \\
\hline $\begin{array}{l}\text { J. Waste Certification. A waste certification program shall be } \\
\text { developed, documented, and implemented to ensure that the waste } \\
\text { acceptance requirements of facilities receiving low-level waste for } \\
\text { storage, treatment, and disposal are met. } \\
\text { From DOE G 435.1-1 Chapter IV: Compliance with the } \\
\text { development and documentation portion of the certification } \\
\text { requirement is demonstrated by a waste certification plan that } \\
\text { identifies the organizations involved, assigns responsibilities for } \\
\text { implementing the program, and describes or references the quality } \\
\text { assurance, training, procurement controls, records management, and } \\
\text { procedures to be used by the program. Acceptable performance for } \\
\text { implementing the program is demonstrated when appropriate } \\
\text { personnel are trained and follow the procedures that govern their } \\
\text { part of the waste certification. Additionally, acceptable performance } \\
\text { is demonstrated if the waste certification plan and procedures are } \\
\text { current and controlled in accordance with a document controls } \\
\text { program, and records related to certification (e.g., certification } \\
\text { statements, training records, procurement records, characterization } \\
\text { records, container records) are generated and managed in accordance } \\
\text { with the established site program. }\end{array}$ & $\begin{array}{l}\text { MCP-17000 §4 specifies the requirements } \\
\text { for preparing an IWTS profile that } \\
\text { captures waste certification information. } \\
\text { MCP-17500 provides the Waste Generator } \\
\text { Services Waste Certification Program for } \\
\text { LLW to be shipped to NNSS. } \\
\text { Container procurement is addressed in } \\
\text { MCP-17000 §4.6. } \\
\text { Waste certification is performed and } \\
\text { tracked using IWTS. Documentation of } \\
\text { the IWTS Program is only available } \\
\text { electronically. } \\
\text { PLN-522 requires waste technical } \\
\text { specialists and waste disposition } \\
\text { specialists to complete the appropriate } \\
\text { training/qualification before being granted } \\
\text { approval authority for profiles within the } \\
\text { IWTS Program. The waste certification } \\
\text { official, alternate waste certification } \\
\text { official, and NNSS packaging certifiers } \\
\text { must complete the appropriate } \\
\text { training/qualifications to disposition waste } \\
\text { to NNSS. }\end{array}$ \\
\hline $\begin{array}{l}\text { (1) Certification Program. The waste certification program shall } \\
\text { designate the officials who have the authority to certify and } \\
\text { release waste for shipment; and specify what documentation is } \\
\text { required for waste generation, characterization, shipment, and } \\
\text { certification. The program shall provide requirements for } \\
\text { auditability, retrievability, and storage of required documentation } \\
\text { and specify the records retention period. } \\
\text { From DOE G 435.1-1 Chapter IV: Compliance with this } \\
\text { requirement is demonstrated by a program or procedure for } \\
\text { record keeping and records showing that low-level waste is } \\
\text { certified as having met the waste acceptance criteria of the } \\
\text { facility to which it was transferred and that the certification } \\
\text { statement is supported by additional records regarding the waste } \\
\text { source, characterization, and container. }\end{array}$ & See J. above. \\
\hline $\begin{array}{l}\text { (2) Certification before Transfer. Low-level waste shall be certified } \\
\text { as meeting waste acceptance requirements before it is transferred } \\
\text { to the facility receiving the waste. } \\
\text { From DOE G } 435.1-1 \text { Chapter IV: Compliance with this } \\
\text { requirement is demonstrated by the presence of a certification } \\
\text { program which includes procedures requiring a signed } \\
\text { certification statement prior to the release of waste for transfer, } \\
\text { and by dated records showing that waste was certified before } \\
\text { being transferred. }\end{array}$ & See J. above. \\
\hline $\begin{array}{l}\text { (3) Maintaining Certification. Low-level waste that has been } \\
\text { certified as meeting the waste acceptance requirements for } \\
\text { transfer to a storage, treatment, or disposal facility shall be }\end{array}$ & See J. above. \\
\hline
\end{tabular}


Table 2. (continued).

\begin{tabular}{|c|c|}
\hline \multicolumn{2}{|c|}{ Facility Name: CPP-653, Cold Waste Handling Facility } \\
\hline Chapter IV, LLW Requirements & Facility Compliance Information \\
\hline $\begin{array}{l}\text { managed in a manner that maintains its certification status. } \\
\text { From DOE G 435.1-1 Chapter IV: Compliance with this } \\
\text { requirement is demonstrated by a program or procedure } \\
\text { reflecting this requirement is present and site personnel are able } \\
\text { to show that the storage of low-level waste containers is in a } \\
\text { facility or manner where the containers would not be damaged by } \\
\text { normal weather events, and cannot be accessed by unauthorized } \\
\text { personnel. Further, each container can be traced to its } \\
\text { certification and the information supporting that certification. }\end{array}$ & \\
\hline $\begin{array}{l}\text { K. Waste Transfer. A documented process shall be established and } \\
\text { implemented for transferring responsibility for management of low- } \\
\text { level waste and for ensuring availability of relevant data. The } \\
\text { following requirements are in addition to those in Chapter I of this } \\
\text { Manual. }\end{array}$ & $\begin{array}{l}\text { MCP-17000 specifies the requirements for } \\
\text { preparing an IWTS profile that captures } \\
\text { waste certification data, transfer } \\
\text { information, and associated } \\
\text { authorizations. }\end{array}$ \\
\hline $\begin{array}{l}\text { From DOE G 435.1-1 Chapter IV: Compliance with this requirement } \\
\text { is demonstrated if facilities have procedures for the receipt of waste } \\
\text { and the transfer of waste, as appropriate, which address the } \\
\text { acquisition of waste and container data and the transfer of } \\
\text { ownership, respectively. Further evidence of acceptable performance } \\
\text { is facility records showing that data on the waste containers is } \\
\text { available and accurate, and that documented transfer of } \\
\text { responsibility occurs. }\end{array}$ & $\begin{array}{l}\text { MCP-17500 provides the Waste Generator } \\
\text { Services Waste Certification Program for } \\
\text { LLW to be shipped to NNSS. }\end{array}$ \\
\hline $\begin{array}{l}\text { (1) Authorization. Low-level waste shall not be transferred to a } \\
\text { storage, treatment, or disposal facility until personnel responsible } \\
\text { for the facility receiving the waste authorize the transfer. }\end{array}$ & See K. above. \\
\hline $\begin{array}{l}\text { From DOE G 435.1-1 Chapter IV: Compliance with this } \\
\text { requirement is demonstrated by sites having procedures that } \\
\text { require a confirmation of authorization before releasing waste for } \\
\text { transfer, and records showing that transfers are made in } \\
\text { accordance with written authorizations. }\end{array}$ & \\
\hline $\begin{array}{l}\text { (2) Data. Waste characterization data, container information, and } \\
\text { generation, storage, treatment, and transportation information for } \\
\text { low-level waste shall be transferred with or be traceable to the } \\
\text { waste. }\end{array}$ & See K. above. \\
\hline $\begin{array}{l}\text { From DOE G 435.1-1 Chapter IV: Compliance with this } \\
\text { requirement is demonstrated if there are procedures requiring that } \\
\text { characterization and container data be provided and maintained } \\
\text { for each low-level waste transfer and documented records of } \\
\text { transfers show that the information is being provided. }\end{array}$ & \\
\hline $\begin{array}{l}\text { L. Packaging and Transportation. The following requirements are in } \\
\text { addition to those in Chapter I of this Manual [DOE M 435.1-1 } \\
\text { §I.1.E(11)]. }\end{array}$ & $\begin{array}{l}\text { DOE Manual 435.1-1 §I.1.E(11) applies } \\
\text { to field element managers. }\end{array}$ \\
\hline $\begin{array}{l}\text { (1) Packaging. If containers are used: } \\
\text { From DOE G 435.1-1 Chapter IV: Compliance with the } \\
\text { packaging requirement is demonstrated by: (1) procedures which } \\
\text { document proper packaging protocols; and (2) no trends of } \\
\text { routine repackaging of low-level waste that is packaged after } \\
\text { issuance of DOE O 435.1. Successful performance of this } \\
\text { requirement is also demonstrated by a record of containers for }\end{array}$ & $\begin{array}{l}\text { MCP-17000 } \$ 4 \text { addresses packaging } \\
\text { requirements. }\end{array}$ \\
\hline
\end{tabular}


Table 2. (continued).

\begin{tabular}{|c|c|}
\hline \multicolumn{2}{|c|}{ Facility Name: CPP-653, Cold Waste Handling Facility } \\
\hline Chapter IV, LLW Requirements & Facility Compliance Information \\
\hline $\begin{array}{l}\text { which failure has not routinely occurred under management } \\
\text { conditions. It is recognized that there may be failed containers for } \\
\text { waste previously placed in storage. For those containers, the goal } \\
\text { is to only have to repackage the waste one time after it is } \\
\text { retrieved and characterized. Further, acceptable performance is } \\
\text { demonstrated by containers of waste having marking and labeling } \\
\text { that allows correlation with waste characterization data and } \\
\text { container information. }\end{array}$ & \\
\hline $\begin{array}{l}\text { (a) Low-level waste shall be packaged in a manner that provides } \\
\text { containment and protection for the duration of the anticipated } \\
\text { storage period and until disposal is achieved or until the waste } \\
\text { has been removed from the container. }\end{array}$ & See (1) above. \\
\hline $\begin{array}{l}\text { (b) When waste is packaged, vents or other measures shall be } \\
\text { provided if the potential exists for pressurizing or generating } \\
\text { flammable or explosive concentrations of gases within the } \\
\text { waste container. }\end{array}$ & See (1) above. \\
\hline $\begin{array}{l}\text { (c) Containers of low-level waste shall be marked such that their } \\
\text { contents can be identified. }\end{array}$ & See (1) above. \\
\hline $\begin{array}{l}\text { (2) Transportation. To the extent practical, the volume of waste and } \\
\text { number of low-level waste shipments shall be minimized. } \\
\text { From DOE G 435.1-1 Chapter IV: Compliance with this } \\
\text { requirement can be demonstrated by a combination of site } \\
\text { procedures directing the efficient use of waste container capacity }\end{array}$ & $\begin{array}{l}\text { MCP-17000 } \S 4 \text { addresses transportation. } \\
\text { The waste disposition specialist } \\
\text { coordinates with packaging and } \\
\text { transportation personnel for waste shipped } \\
\text { offsite from this facility. }\end{array}$ \\
\hline $\begin{array}{l}\text { and documentation showing that low-level waste shipments are } \\
\text { systematically planned and optimized to the extent practical. }\end{array}$ & $\begin{array}{l}\text { Waste is shipped directly to NNSS from } \\
\text { this facility. MCP-17500 specifies the } \\
\text { waste certification official and waste } \\
\text { disposition specialist responsibilities and } \\
\text { coordination with packaging and } \\
\text { transportation personnel. }\end{array}$ \\
\hline $\begin{array}{l}\text { M. Site Evaluation and Facility Design. The following requirements are } \\
\text { in addition to those in Chapter I of this Manual. }\end{array}$ & $\begin{array}{l}\text { NA; this requirement addresses new } \\
\text { radioactive waste management facilities. }\end{array}$ \\
\hline $\begin{array}{l}\text { (1) Site Evaluation. Proposed locations for low-level waste facilities } \\
\text { shall be evaluated to identify relevant features that should be } \\
\text { avoided or must be considered in facility design and analyses. }\end{array}$ & See M. above. \\
\hline $\begin{array}{l}\text { (a) Each site proposed for a new low-level waste facility or } \\
\text { expansion of an existing low-level waste facility shall be } \\
\text { evaluated considering environmental characteristics, } \\
\text { geotechnical characteristics, and human activities, including } \\
\text { for a low-level waste disposal facility, the capability of the } \\
\text { site to demonstrate, at a minimum, whether it is: }\end{array}$ & See M. above. \\
\hline $\begin{array}{l}1 \text { Located to accommodate the projected volume of waste to } \\
\text { be received; }\end{array}$ & See M. above. \\
\hline $\begin{array}{l}2 \text { Located in a flood plain, a tectonically active area, or in the } \\
\text { zone of water table fluctuation; and }\end{array}$ & See M. above. \\
\hline $\begin{array}{l}3 \text { Located where radionuclide migration pathways are } \\
\text { predictable and erosion and surface runoff can be } \\
\text { controlled. }\end{array}$ & See M. above. \\
\hline (b) Proposed sites with environmental characteristics, & See M. above. \\
\hline
\end{tabular}


Table 2. (continued).

Facility Name: CPP-653, Cold Waste Handling Facility

\begin{tabular}{|c|c|}
\hline Chapter IV, LLW Requirements & Facility Compliance Information \\
\hline $\begin{array}{l}\text { geotechnical characteristics, and human activities for which } \\
\text { adequate protection cannot be provided through facility } \\
\text { design shall be deemed unsuitable for the location of the } \\
\text { facility. }\end{array}$ & \\
\hline $\begin{array}{l}\text { (c) Low-level waste disposal facilities shall be sited to achieve } \\
\text { long-term stability and to minimize, to the extent practical, } \\
\text { the need for active maintenance following final closure. }\end{array}$ & See M. above. \\
\hline $\begin{array}{l}\text { (2) Low-Level Waste Treatment and Storage Facility Design. The } \\
\text { following facility requirements and general design criteria, at a } \\
\text { minimum, apply: }\end{array}$ & See M. above. \\
\hline $\begin{array}{l}\text { (a) Confinement. Low-level waste systems and components shall } \\
\text { be designed to maintain waste confinement. }\end{array}$ & See M. above. \\
\hline (b) Ventilation. & See M. above. \\
\hline $\begin{array}{l}1 \text { Design of low-level waste treatment and storage facilities } \\
\text { shall include ventilation, if applicable, through an } \\
\text { appropriate filtration system to maintain the release of } \\
\text { radioactive material in airborne effluents within the } \\
\text { requirements and guidelines specified in applicable } \\
\text { requirements. }\end{array}$ & See M. above. \\
\hline $\begin{array}{l}2 \text { When conditions exist for generating gases in flammable or } \\
\text { explosive concentrations, ventilation systems or other } \\
\text { measures shall be provided to keep the gases in a non- } \\
\text { flammable and nonexplosive condition. Where } \\
\text { concentrations of explosive or flammable gases are } \\
\text { expected to approach the lower flammability limit, } \\
\text { measures shall be taken to prevent deflagration or } \\
\text { detonation. }\end{array}$ & See M. above. \\
\hline $\begin{array}{l}\text { (c) Consideration of Decontamination and Decommissioning. } \\
\text { Areas in new and modifications to existing low-level waste } \\
\text { management facilities that are subject to contamination with } \\
\text { radioactive or other hazardous materials shall be designed to } \\
\text { facilitate decontamination. For such facilities a proposed } \\
\text { decommissioning method or a conversion method leading to } \\
\text { reuse shall be described. }\end{array}$ & See M. above. \\
\hline $\begin{array}{l}\text { (d) Instrumentation and Control Systems. Engineering controls } \\
\text { shall be incorporated in the design and engineering of low- } \\
\text { level waste treatment and storage facilities to provide volume } \\
\text { inventory data and to prevent spills, leaks, and overflows } \\
\text { from tanks or confinement systems. }\end{array}$ & See M. above. \\
\hline $\begin{array}{l}\text { (e) Monitoring. Monitoring and/or leak detection capabilities } \\
\text { shall be incorporated in the design and engineering of low- } \\
\text { level waste treatment and storage facilities to provide rapid } \\
\text { identification of failed confinement and/or other abnormal } \\
\text { conditions. }\end{array}$ & See M. above. \\
\hline $\begin{array}{l}\text { (3) Low-Level Waste Disposal Facility Design. The following } \\
\text { facility requirements and general design criteria, at a minimum, } \\
\text { apply: }\end{array}$ & See M. above. \\
\hline $\begin{array}{l}\text { (a) Confinement. Low-level waste systems and components shall } \\
\text { be designed to maintain waste confinement. }\end{array}$ & See M. above. \\
\hline
\end{tabular}


Table 2. (continued).

\begin{tabular}{|c|c|}
\hline \multicolumn{2}{|c|}{ Facility Name: CPP-653, Cold Waste Handling Facility } \\
\hline Chapter IV, LLW Requirements & Facility Compliance Information \\
\hline (b) Ventilation. & See M. above. \\
\hline $\begin{array}{l}\text { Design of low-level waste disposal facilities shall include } \\
\text { ventilation, if applicable, through an appropriate filtration } \\
\text { system to maintain the release of radioactive material in } \\
\text { airborne effluents within the requirements and guidelines } \\
\text { specified in applicable requirements. }\end{array}$ & See M. above. \\
\hline $\begin{array}{l}2 \text { When conditions exist for generating gases in flammable or } \\
\text { explosive concentrations, ventilation systems or other } \\
\text { measures shall be provided to keep the gases in a non- } \\
\text { flammable and non-explosive condition. Where } \\
\text { concentrations of explosive or flammable gases are } \\
\text { expected to approach the lower flammability limit, } \\
\text { measures shall be taken to prevent deflagration or } \\
\text { detonation. }\end{array}$ & See M. above. \\
\hline $\begin{array}{l}\text { (c) Stability. Low-level waste disposal facilities shall be designed } \\
\text { to achieve long-term stability and to minimize to the extent } \\
\text { practical, the need for active maintenance following final } \\
\text { closure. }\end{array}$ & See M. above. \\
\hline $\begin{array}{l}\text { (d) Control of Water. Low-level waste disposal facilities shall be } \\
\text { designed to minimize to the extent practical, the contact of } \\
\text { waste with water during and after disposal. }\end{array}$ & See M. above. \\
\hline $\begin{array}{l}\text { N. Storage and Staging. The following requirements are in addition to } \\
\text { those in Chapter I of this Manual [DOE M 435.1-1 §I.2.F(13)]. }\end{array}$ & $\begin{array}{l}\text { DOE Manual 435.1-1 §I.2.F(13) applies to } \\
\text { field element managers. }\end{array}$ \\
\hline $\begin{array}{l}\text { (1) Storage Prohibitions. Low-level waste in storage shall not be } \\
\text { readily capable of detonation, explosive decomposition, reaction } \\
\text { at anticipated pressures and temperatures, or explosive reaction } \\
\text { with water. Prior to storage, pyrophoric materials shall be treated, } \\
\text { prepared, and packaged to be nonflammable. }\end{array}$ & NA; this facility does not store LLW. \\
\hline $\begin{array}{l}\text { From DOE G 435.1-1 Chapter IV: Compliance with this } \\
\text { requirement is demonstrated by having waste acceptance } \\
\text { requirements which prohibit low-level waste that is ignitable or } \\
\text { explosive from being accepted for storage unless it has been } \\
\text { treated, and procedures for properly preparing such materials for } \\
\text { safe storage. }\end{array}$ & \\
\hline $\begin{array}{l}\text { (2) Storage Limit. Low-level waste that has an identified path to } \\
\text { disposal shall not be stored longer than one year prior to disposal, } \\
\text { except for storage for decay, or as otherwise authorized by the } \\
\text { Field Element Manager. }\end{array}$ & $\begin{array}{l}\text { NA; this facility does not store LLW. See } \\
\text { N. (7) below for staging requirements. }\end{array}$ \\
\hline $\begin{array}{l}\text { From DOE G 435.1-1 Chapter IV: Storage longer than one year } \\
\text { can be justified if the conditions for such storage are approved by } \\
\text { the Field Element Manager as part of the radioactive waste } \\
\text { management basis for the facility. }\end{array}$ & \\
\hline $\begin{array}{l}\text { Storage for radioactive decay for a period greater than } 1 \text { year for } \\
\text { waste that has an identified path to disposal is allowed. Adequate } \\
\text { justification and the supporting information for storage for decay } \\
\text { is to be documented in the radioactive waste management basis } \\
\text { for the facility in which the storage will take place. }\end{array}$ & \\
\hline $\begin{array}{l}\text { (a) Mixed waste. Under the Federal Facility Compliance Act of } \\
\text { 1992, DOE sites were required to develop Site Treatment }\end{array}$ & \\
\hline
\end{tabular}


Table 2. (continued).

Facility Name: CPP-653, Cold Waste Handling Facility

Chapter IV, LLW Requirements

Plans to bring stored mixed low-level waste into compliance with these requirements. The Site Treatment Plan needs to be consulted and any mixed low-level waste stored for the purpose of accumulation to facilitate treatment must meet Resource Conservation and Recovery Act storage requirements. There could be several ways within different scenarios that this requirement can be met, as illustrated by the examples below, however, there are basically four ways to show compliance with the requirement and include appropriate provisions in the radioactive waste management basis for the facility in which it is stored.

(b) Legacy waste. As discussed above, the intention of the requirement is not to force malicious compliance or heroic actions which would result in increased risk or safety concerns. Rather, the intention is that waste in storage longer than one year receives additional attention to ensure that the public, the workers, and the environment are protected from the hazards of the waste, and that progress is being made to dispose of the waste. There could be several ways within different scenarios that this requirement can be met, as illustrated by the examples below, however, there are basically four ways to show compliance with the requirement:

1 the radioactive waste management basis allows for storage for no more than one year.

2 the radioactive waste management basis allows for storage for no more than one year, or for storage for decay only for periods greater than a year, which are specified on a radionuclide basis.

3 the radioactive waste management basis allows for storage for more than one year, up to a specified period of time based on a documented technical evaluation that the waste can be stored in a manner that does not cause changes to the waste or waste packages that is detrimental to the safe storage of the waste, the final disposal of the waste or to meeting the disposal performance objectives.

4 the radioactive waste management basis allows for storage for decay (with specifics) and for storage for more than one year for other low-level waste, up to a specified period of time based on a documented technical evaluation that the waste can be stored in a manner that does not cause changes to the waste or waste packages that is detrimental to the safe storage of the waste, the final disposal of the waste or to meeting the disposal performance objectives.

Compliance with this requirement is demonstrated by the existence of a radioactive waste management basis for the storage facility approved by the Field Element Manager that includes the time frames that waste are allowed to be stored, the necessary justifications for storage for decay, and the necessary technical evaluations if storage is to extend significantly beyond the one-year time frame. 
Table 2. (continued).

\begin{tabular}{|c|c|}
\hline \multicolumn{2}{|c|}{ Facility Name: CPP-653, Cold Waste Handling Facility } \\
\hline Chapter IV, LLW Requirements & \begin{tabular}{|l|} 
Facility Compliance Information \\
\end{tabular} \\
\hline $\begin{array}{l}\text { (3) Storage Integrity. Low-level waste shall be stored in a location } \\
\text { and manner that protects the integrity of waste for the expected } \\
\text { time of storage and minimizes worker exposure. }\end{array}$ & $\begin{array}{l}\text { NA; this facility does not store LLW. See } \\
\text { N. (7) below for staging requirements. }\end{array}$ \\
\hline $\begin{array}{l}\text { From DOE G 435.1-1 Chapter IV: However, in making a } \\
\text { decision to use a facility for storage and in developing a } \\
\text { radioactive waste management basis for the activity, particular } \\
\text { attention to protection of workers is needed. }\end{array}$ & \\
\hline $\begin{array}{l}\text { Compliance with this requirement is demonstrated if sites have } \\
\text { storage capabilities for low-level waste that provide protection to } \\
\text { waste containers so that their integrity will not be damaged } \\
\text { through physical or chemical (corrosion) processes and that keep } \\
\text { personnel from spending extended periods of time in the areas } \\
\text { where low-level waste is stored. }\end{array}$ & \\
\hline (4) Waste Characterization for Storage. & $\begin{array}{l}\text { NA; this facility does not store LLW. See } \\
\text { N. (7) below for staging requirements. }\end{array}$ \\
\hline $\begin{array}{l}\text { (a) Low-level waste that does not have an identified path to } \\
\text { disposal shall be characterized as necessary to meet the data } \\
\text { quality objectives and minimum characterization } \\
\text { requirements of this Chapter, to ensure safe storage, and to } \\
\text { facilitate disposal. }\end{array}$ & $\begin{array}{l}\text { NA; this facility does not store LLW. See } \\
\text { N. (7) below for staging requirements. }\end{array}$ \\
\hline $\begin{array}{l}\text { (b) Characterization information for all low-level waste in } \\
\text { storage shall be maintained as a record in accordance with the } \\
\text { requirements for Records Management in Chapter I of this } \\
\text { Manual. } \\
\text { From DOE G 435.1-1 Chapter IV: Compliance with this } \\
\text { requirement is demonstrated by documented procedures for } \\
\text { managing waste characterization and container information } \\
\text { on low-level waste as a Federal record. The records are } \\
\text { managed per the applicable policies and procedures for } \\
\text { records management referenced in DOE O } 200.1 \text { and } \\
\text { established at the applicable Field Element. }\end{array}$ & $\begin{array}{l}\text { NA; this facility does not store LLW. See } \\
\text { N. (7) below for staging requirements. }\end{array}$ \\
\hline $\begin{array}{l}\text { (5) Container Inspection. A process shall be developed and } \\
\text { implemented for inspecting and maintaining containers of low- } \\
\text { level waste to ensure container integrity is not compromised. } \\
\text { From DOE G } 435.1-1 \text { Chapter IV: Compliance with this } \\
\text { requirement is demonstrated by: (1) a documented process for } \\
\text { waste container inspection and maintenance; and (2) } \\
\text { documentation for all waste container inspections and } \\
\text { maintenance actions performed. }\end{array}$ & $\begin{array}{l}\text { LI- } 435 \text { requires quarterly inspections of } \\
\text { radioactive waste containers if waste is } \\
\text { stored outdoors or has been in storage for } \\
\text { greater than } 1 \text { year. }\end{array}$ \\
\hline $\begin{array}{l}\text { (6) Storage Management. Low-level waste storage shall be managed } \\
\text { to identify and segregate low-level waste from mixed low-level } \\
\text { waste. }\end{array}$ & $\begin{array}{l}\text { NA; this facility does not store LLW. See } \\
\text { N. (7) below for staging requirements. }\end{array}$ \\
\hline $\begin{array}{l}\text { (7) Staging. Staging of low-level waste shall be for the purpose of } \\
\text { the accumulation of such quantities of waste as necessary to } \\
\text { facilitate transportation, treatment, and disposal. Staging longer } \\
\text { than } 90 \text { days shall meet the requirements for storage above and in } \\
\text { Chapter I of this Manual. } \\
\text { From DOE G } 435.1-1 \text { Chapter IV: The staging of low-level } \\
\text { waste needs to be addressed in the radioactive waste management }\end{array}$ & $\begin{array}{l}\text { Routine LLW, such as personal protective } \\
\text { equipment, is accumulated at this facility } \\
\text { for disposal. MCP-17000, Appendix F, } \\
\text { "Container Start Date and Storage } \\
\text { Prohibitions," restricts staging LLW to a } \\
\text { 90-day maximum at any generator or } \\
\text { treatment facility prior to acceptance by a }\end{array}$ \\
\hline
\end{tabular}


Table 2. (continued).

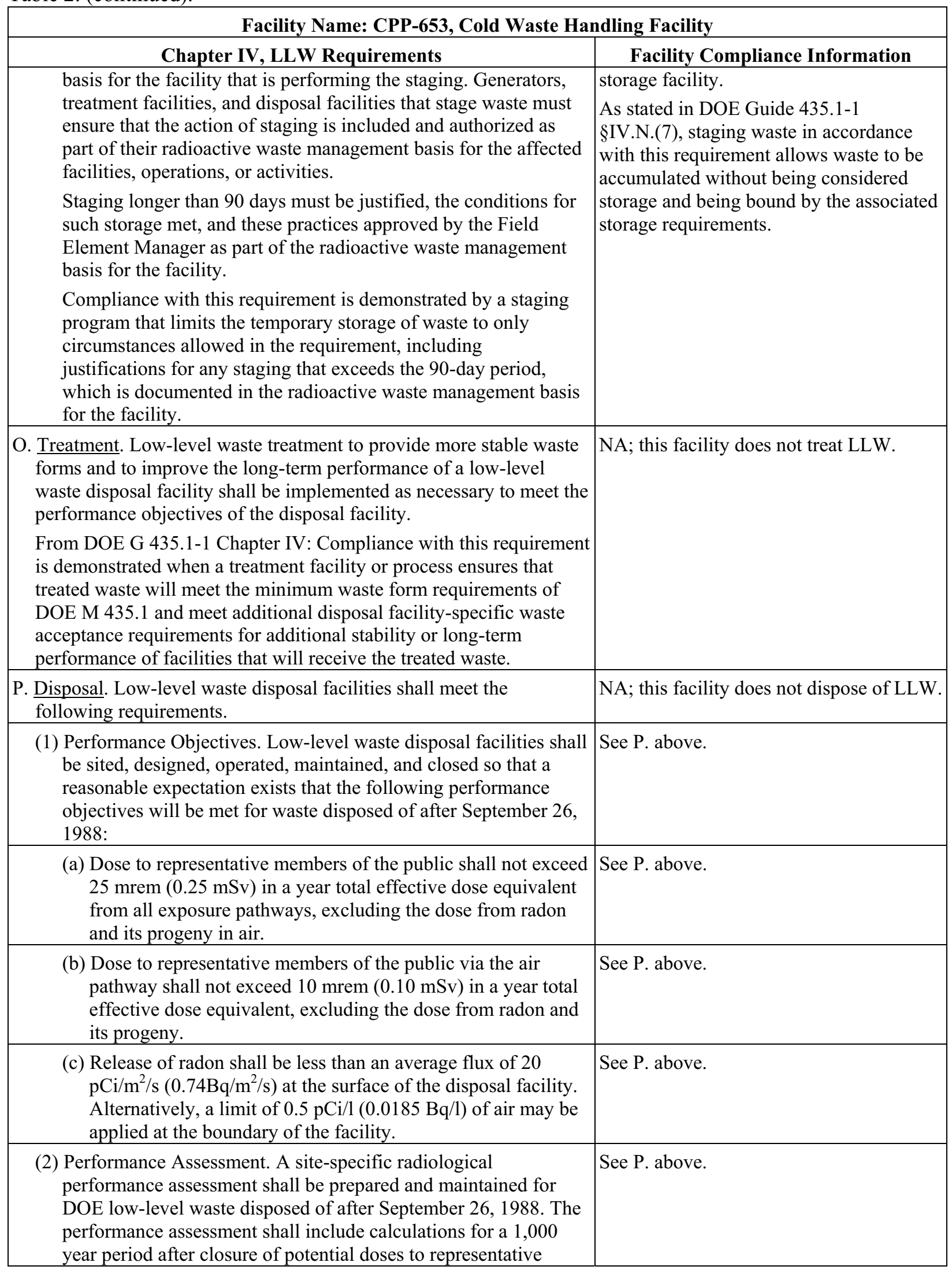


Table 2. (continued).

Facility Name: CPP-653, Cold Waste Handling Facility

Chapter IV, LLW Requirements Facility Compliance Information

future members of the public and potential releases from the facility to provide a reasonable expectation that the performance objectives identified in this Chapter are not exceeded as a result of operation and closure of the facility.

(a) Analyses performed to demonstrate compliance with the performance objectives in this Chapter, and to establish limits on concentrations of radionuclides for disposal based on the performance measures for inadvertent intruders in this Chapter shall be based on reasonable activities in the critical group of exposed individuals. Unless otherwise specified, the assumption of average living habits and exposure conditions in representative critical groups of individuals projected to receive the highest doses is appropriate. The likelihood of inadvertent intruder scenarios may be considered in interpreting the results of the analyses and establishing radionuclide concentrations, if adequate justification is provided.

(b) The point of compliance shall correspond to the point of highest projected dose or concentration beyond a 100 meter buffer zone surrounding the disposed waste. A larger or smaller buffer zone may be used if adequate justification is provided.

(c) Performance assessments shall address reasonably foreseeable See P. above. natural processes that might disrupt barriers against release and transport of radioactive materials.

(d) Performance assessments shall use DOE-approved dose coefficients (dose conversion factors) for internal and external exposure of reference adults.

(e) The performance assessment shall include a sensitivity/uncertainty analysis.

(f) Performance assessments shall include a demonstration that projected releases of radionuclides to the environment shall be maintained as low as reasonably achievable (ALARA).

(g) For purposes of establishing limits on radionuclides that may See P. above. be disposed of near-surface, the performance assessment shall include an assessment of impacts to water resources.

(h) For purposes of establishing limits on the concentration of radionuclides that may be disposed of near-surface, the performance assessment shall include an assessment of impacts calculated for a hypothetical person assumed to inadvertently intrude for a temporary period into the low-level waste disposal facility. For intruder analyses, institutional controls shall be assumed to be effective in deterring intrusion for at least 100 years following closure. The intruder analyses shall use performance measures for chronic and acute exposure scenarios, respectively, of $100 \mathrm{mrem}(1 \mathrm{mSv})$ in a year and $500 \mathrm{mrem}(5 \mathrm{mSv})$ total effective dose equivalent excluding radon in air.

(3) Composite Analysis. For disposal facilities which received waste See P. above. 
Table 2. (continued).

Facility Name: CPP-653, Cold Waste Handling Facility

\begin{tabular}{|c|c|}
\hline Chapter IV, LLW Requirements & Facility Compliance Information \\
\hline $\begin{array}{l}\text { after September } 26,1988 \text {, a site-specific radiological composite } \\
\text { analysis shall be prepared and maintained that accounts for all } \\
\text { sources of radioactive material that may be left at the DOE site } \\
\text { and may interact with the low- level waste disposal facility, } \\
\text { contributing to the dose projected to a hypothetical member of } \\
\text { the public from the existing or future disposal facilities. } \\
\text { Performance measures shall be consistent with DOE } \\
\text { requirements for protection of the public and environment and } \\
\text { evaluated for a } 1,000 \text { year period following disposal facility } \\
\text { closure. The composite analysis results shall be used for } \\
\text { planning, radiation protection activities, and future use } \\
\text { commitments to minimize the likelihood that current low- level } \\
\text { waste disposal activities will result in the need for future } \\
\text { corrective or remedial actions to adequately protect the public } \\
\text { and the environment. }\end{array}$ & \\
\hline $\begin{array}{l}\text { (4) Performance Assessment and Composite Analysis Maintenance. } \\
\text { The performance assessment and composite analysis shall be } \\
\text { maintained to evaluate changes that could affect the performance, } \\
\text { design, and operating bases for the facility. Performance } \\
\text { assessment and composite analysis maintenance shall include the } \\
\text { conduct of research, field studies, and monitoring needed to } \\
\text { address uncertainties or gaps in existing data. The performance } \\
\text { assessment shall be updated to support the final facility closure. } \\
\text { Additional iterations of the performance assessment and } \\
\text { composite analysis shall be conducted as necessary during the } \\
\text { post-closure period. }\end{array}$ & See P. above. \\
\hline $\begin{array}{l}\text { (a) Performance assessments and composite analyses shall be } \\
\text { reviewed and revised when changes in waste forms or } \\
\text { containers, radionuclide inventories, facility design and } \\
\text { operations, closure concepts, or the improved understanding } \\
\text { of the performance of the waste disposal facility in } \\
\text { combination with the features of the site on which it is located } \\
\text { alter the conclusions or the conceptual model(s) of the } \\
\text { existing performance assessment or composite analysis. }\end{array}$ & See P. above. \\
\hline $\begin{array}{l}\text { (b) A determination of the continued adequacy of the } \\
\text { performance assessment and composite analysis shall be } \\
\text { made on an annual basis, and shall consider the results of data } \\
\text { collection and analysis from research, field studies, and } \\
\text { monitoring. }\end{array}$ & See P. above. \\
\hline $\begin{array}{l}\text { (c) Annual summaries of low-level waste disposal operations } \\
\text { shall be prepared with respect to the conclusions and } \\
\text { recommendations of the performance assessment and } \\
\text { composite analysis and a determination of the need to revise } \\
\text { the performance assessment or composite analysis. }\end{array}$ & See P. above. \\
\hline $\begin{array}{l}\text { (5) Disposal Authorization. A disposal authorization statement shall } \\
\text { be obtained prior to construction of a new low-level waste } \\
\text { disposal facility. Field Elements with existing low-level waste } \\
\text { disposal facilities shall obtain a disposal authorization statement } \\
\text { in accordance with the schedule in the Complex-Wide Low- } \\
\text { Level Waste Management Program Plan. The disposal } \\
\text { authorization statement shall be issued based on a review of the }\end{array}$ & See P. above. \\
\hline
\end{tabular}


Table 2. (continued).

\begin{tabular}{|c|c|}
\hline \multicolumn{2}{|c|}{ Facility Name: CPP-653, Cold Waste Handling Facility } \\
\hline Chapter IV, LLW Requirements & Facility Compliance Information \\
\hline $\begin{array}{l}\text { facility's performance assessment, composite analysis, } \\
\text { performance assessment and composite analysis maintenance, } \\
\text { preliminary closure plan, and preliminary monitoring plan. The } \\
\text { disposal authorization statement shall specify the limits and } \\
\text { conditions on construction, design, operations, and closure of the } \\
\text { low-level waste facility based on these reviews. A disposal } \\
\text { authorization statement is a part of the radioactive waste } \\
\text { management basis for a disposal facility. Failure to obtain a } \\
\text { disposal authorization statement by the implementation date of } \\
\text { this Order shall result in shutdown of the disposal facility. }\end{array}$ & \\
\hline $\begin{array}{l}\text { (6) Disposal Facility Operations. The disposal facility design and } \\
\text { operation must be consistent with the disposal facility closure } \\
\text { plan and lead to disposal facility closure that provides a } \\
\text { reasonable expectation that performance objectives will be met. } \\
\text { Low-level waste shall be disposed in such a manner that achieves } \\
\text { the performance objectives stated in this Chapter, consistent with } \\
\text { the disposal facility radiological performance assessment. } \\
\text { Additional requirements include: }\end{array}$ & See P. above. \\
\hline $\begin{array}{l}\text { (a) Operating procedures shall be developed and implemented for } \\
\text { low-level waste disposal facilities that protect the public, } \\
\text { workers, and the environment; ensure the security of the } \\
\text { facility; minimize subsidence during and after waste } \\
\text { emplacement; achieve long-term stability and minimize the } \\
\text { need for long-term active maintenance; and meet the } \\
\text { requirements of the closure/post-closure plan. }\end{array}$ & See P. above. \\
\hline $\begin{array}{l}\text { (b) Permanent identification markers for disposal excavations } \\
\text { and monitoring wells shall be emplaced. }\end{array}$ & See P. above. \\
\hline $\begin{array}{l}\text { (c) Low-level waste placement into disposal units shall minimize } \\
\text { voids between waste containers. Voids within disposal units } \\
\text { shall be filled to the extent practical. Uncontainerized bulk } \\
\text { waste shall also be placed in a manner that minimizes voids } \\
\text { and subsidence. }\end{array}$ & See P. above. \\
\hline $\begin{array}{l}\text { (d) Operations are to be conducted so that active waste disposal } \\
\text { operations will not have an adverse effect on any other } \\
\text { disposal units. }\end{array}$ & See P. above. \\
\hline $\begin{array}{l}\text { (e) Operations shall include a process for tracking and } \\
\text { documenting low-level waste placement in the facility by } \\
\text { generator source. }\end{array}$ & See P. above. \\
\hline $\begin{array}{l}\text { (7) Alternate Requirements for Low-Level Waste Disposal Facility } \\
\text { Design and Operation. Requirements other than those set forth in } \\
\text { this Section for the design and operation of a low-level waste } \\
\text { disposal facility may be approved on a specific basis if a } \\
\text { reasonable expectation is demonstrated that the disposal } \\
\text { performance objectives will be met. }\end{array}$ & See P. above. \\
\hline $\begin{array}{l}\text { Q. Closure. The following requirements are in addition to those in } \\
\text { Chapter I of this Manual. }\end{array}$ & NA; this facility does not dispose of LLW. \\
\hline $\begin{array}{l}\text { (1) Disposal Facility Closure Plans. A preliminary closure plan shall } \\
\text { be developed and submitted to Headquarters for review with the } \\
\text { performance assessment and composite analysis. The closure }\end{array}$ & See Q. above. \\
\hline
\end{tabular}


Table 2. (continued).

\begin{tabular}{|c|c|}
\hline \multicolumn{2}{|c|}{ Facility Name: CPP-653, Cold Waste Handling Facility } \\
\hline Chapter IV, LLW Requirements & Facility Compliance Information \\
\hline $\begin{array}{l}\text { plan shall be updated following issuance of the disposal } \\
\text { authorization statement to incorporate conditions specified in the } \\
\text { disposal authorization statement. Closure plans shall: }\end{array}$ & \\
\hline $\begin{array}{l}\text { (a) Be updated as required during the operational life of the } \\
\text { facility. }\end{array}$ & See Q. above. \\
\hline $\begin{array}{l}\text { (b) Include a description of how the disposal facility will be } \\
\text { closed to achieve long-term stability and minimize the need } \\
\text { for active maintenance following closure and to ensure } \\
\text { compliance with the requirements of DOE 5400.5, Radiation } \\
\text { Protection of the Public and the Environment. }\end{array}$ & See Q. above. \\
\hline $\begin{array}{l}\text { (c) Include the total expected inventory of wastes to be disposed } \\
\text { of at the facility over the operational life of the facility. }\end{array}$ & See Q. above. \\
\hline $\begin{array}{l}\text { (2) Disposal Facility Closure. Closure of a disposal facility shall } \\
\text { occur within a five-year period after it is filled to capacity, or } \\
\text { after the facility is otherwise determined to be no longer needed. }\end{array}$ & See Q. above. \\
\hline $\begin{array}{l}\text { (a) Prior to facility closure, the final inventory of the low-level } \\
\text { waste disposed in the facility shall be prepared and } \\
\text { incorporated in the performance assessment and composite } \\
\text { analysis which shall be updated to support the closure of the } \\
\text { facility. }\end{array}$ & See Q. above. \\
\hline $\begin{array}{l}\text { (b) A final closure plan shall be prepared based on the final } \\
\text { inventory of waste disposed in the facility, the plan } \\
\text { implemented, and the updated performance assessment and } \\
\text { composite analysis prepared in support of the facility closure. }\end{array}$ & See Q. above. \\
\hline $\begin{array}{l}\text { (c) Institutional control measures shall be integrated into land use } \\
\text { and stewardship plans and programs, and shall continue until } \\
\text { the facility can be released pursuant to DOE } 5400.5 \text {, } \\
\text { Radiation Protection of the Public and the Environment. }\end{array}$ & See Q. above. \\
\hline $\begin{array}{l}\text { (d) The location and use of the facility shall be filed with the } \\
\text { local authorities responsible for land use and zoning. }\end{array}$ & See Q. above. \\
\hline $\begin{array}{l}\text { R. Monitoring. The following requirements are in addition to those in } \\
\text { Chapter I of this Manual [DOE M 435.1-1 §I.1.E(7)]. }\end{array}$ & $\begin{array}{l}\text { DOE Manual 435.1-1 §I.1.E(7) applies to } \\
\text { field element managers. }\end{array}$ \\
\hline $\begin{array}{l}\text { (1) All Waste Facilities. Parameters that shall be sampled or } \\
\text { monitored, at a minimum, include: temperature, pressure (for } \\
\text { closed systems), radioactivity in ventilation exhaust and liquid } \\
\text { effluent streams, and flammable or explosive mixtures of gases. } \\
\text { Facility monitoring programs shall include verification that } \\
\text { passive and active control systems have not failed. } \\
\text { From DOE G } 435.1-1 \text { Chapter IV: The minimum parameters } \\
\text { specified in the requirement were selected based on their }\end{array}$ & $\begin{array}{l}\text { Monitoring requirements at INL } \\
\text { radioactive waste management facilities } \\
\text { are tailored for the specific facility to } \\
\text { enable timely indication of developing } \\
\text { problems. Existing radiological control } \\
\text { procedures and assessments are } \\
\text { followed/completed to monitor waste } \\
\text { facilities. }\end{array}$ \\
\hline $\begin{array}{l}\text { potential significance for anticipating and identifying undesirable } \\
\text { conditions at low-level waste management facilities. Each } \\
\text { facility's radioactive waste management basis should include an } \\
\text { evaluation of the applicability and significance of the minimum } \\
\text { parameters. This evaluation also needs to consider additional } \\
\text { parameters to be sampled or monitored to ensure the protection } \\
\text { of the public health, the environment, and the workers. If a } \\
\text { minimum parameter specified in the requirement is deemed to be } \\
\text { not applicable in any way to the active operation of that facility, }\end{array}$ & $\begin{array}{l}\text { LRD-15001 and MCP-139 specify } \\
\text { methods and frequency of radiological } \\
\text { control surveys of all radiological areas. } \\
\text { MCP-139 specifies the use of } \\
\text { Form } 441 . \text { A34. This form is referred to as } \\
\text { the "routine sheet" and is to be used by } \\
\text { facility radiological control foremen to list } \\
\text { radiological areas that are to be surveyed, } \\
\text { the survey periods, and methods. }\end{array}$ \\
\hline
\end{tabular}


Table 2. (continued).

\begin{tabular}{|c|c|}
\hline \multicolumn{2}{|c|}{ Facility Name: CPP-653, Cold Waste Handling Facility } \\
\hline Chapter IV, LLW Requirements & Facility Compliance Information \\
\hline $\begin{array}{l}\text { then that justification should be included in the radioactive waste } \\
\text { management basis and when approved constitutes an exemption } \\
\text { to the manual. }\end{array}$ & \\
\hline $\begin{array}{l}\text { Verification activities are part of the radioactive waste } \\
\text { management basis as a condition for operation and documented } \\
\text { appropriately. }\end{array}$ & \\
\hline $\begin{array}{l}\text { Compliance with this requirement is demonstrated if monitoring } \\
\text { or sampling for the stated parameters is performed for all } \\
\text { facilities with a precision, accuracy, and frequency consistent } \\
\text { with timely identification of developing problems and a } \\
\text { justification exists in the approved radioactive waste } \\
\text { management basis for those specified parameters which are not } \\
\text { monitored or sampled. }\end{array}$ & \\
\hline $\begin{array}{l}\text { (2) Liquid Waste Storage Facilities. For facilities storing liquid low- } \\
\text { level waste, the following shall also be monitored: liquid level } \\
\text { and/or waste volume, and significant waste chemistry } \\
\text { parameters. }\end{array}$ & $\begin{array}{l}\text { NA; liquid LLW is not stored in this } \\
\text { facility. }\end{array}$ \\
\hline $\begin{array}{l}\text { (3) Disposal Facilities. A preliminary monitoring plan for a low- } \\
\text { level waste disposal facility shall be prepared and submitted to } \\
\text { Headquarters for review with the performance assessment and } \\
\text { composite analysis. The monitoring plan shall be updated within } \\
\text { one year following issuance of the disposal authorization } \\
\text { statement to incorporate and implement conditions specified in } \\
\text { the disposal authorization statement. }\end{array}$ & NA; this facility does not dispose of LLW \\
\hline $\begin{array}{l}\text { (a) The site-specific performance assessment and composite } \\
\text { analysis shall be used to determine the media, locations, } \\
\text { radionuclides, and other substances to be monitored. }\end{array}$ & See (3) above. \\
\hline $\begin{array}{l}\text { (b) The environmental monitoring program shall be designed to } \\
\text { include measuring and evaluating releases, migration of } \\
\text { radionuclides, disposal unit subsidence, and changes in } \\
\text { disposal facility and disposal site parameters which may } \\
\text { affect long-term performance. }\end{array}$ & See (3) above. \\
\hline $\begin{array}{l}\text { (c) The environmental monitoring programs shall be capable of } \\
\text { detecting changing trends in performance to allow application } \\
\text { of any necessary corrective action prior to exceeding the } \\
\text { performance objectives in this Chapter. }\end{array}$ & See (3) above. \\
\hline
\end{tabular}

\subsection{CPP-1634, Technology Development Facility}

1. Facility description: The facility is a metal-sided high bay with a 10-ton overhead crane. Beneath the crane rails, heating, ventilating, and air conditioning ducting runs in a north-south direction on both sides of the building about $25 \mathrm{ft}$ above grade. At one time, a high-efficiency particulate air filtered ventilation system was located outside and adjacent to the west side of the building and supported drum venting operations. Presently, there are no dosimetry requirements for entry and no monitoring requirements for exit.

CPP-1634 was originally designed as a fluorinel dissolution development and support facility in the late 1980s. The building was constructed in approximately 1993 and was used to support venting and headspace gas sampling of $\mathrm{CH}$ and remote-handled TRU waste drums. Information found in the 
Electronic Document Management System indicates that drum venting operations were performed from 2006 through early 2008 and that these operations involved venting of non-primary TRU waste containers only. By mid-2008, operations in the facility had ceased and the building was empty awaiting demolition or mission change. During operations, the facility was categorized a Hazard Category 2 nuclear facility.

Nearly two dozen radiological surveys were performed, dating from January 9, 2008, through April 17, 2008 (during operations), with all surveys indicating no detectable contamination in excess of applicable surface contamination limits in the building. Contamination and direct radiation surveys included building general areas; various items that included drums, boxes, and overpack lids; high-efficiency particulate air vacuums; a containment tent and glovebox apparatus; and adjacent areas. Information found on the Electronic Document Management System indicates the containment tent was surveyed, free released, and disposed of in the Central Facilities Area industrial (i.e., non-radiological) landfill. No surveys were found of the crane or crane hook. A radiological survey was performed April 8, 2010, (see Appendix A) prior to turnover of the facility to BEA. Results of the survey showed no radioactive contamination or direct radiation above normal background levels up to $6 \mathrm{ft}$ above the floor. There is presently no radioactive material in the facility.

CPP-1634 will be maintained as a multiple use facility for various INL programs. Present plans are to process laboratory-scale ceramic dummy fuel pellets using depleted uranium oxide or 5 to $7 \%$ enriched uranium powders in high-efficiency particulate air-filtered ventilation hoods. Processing will consist of mixing, grinding, pressing, and sintering in a furnace operating between 400 and $1,600^{\circ} \mathrm{C}$. Future processes also may require use of gloveboxes, benchtop work, and a dry bag isostatic press (which could create a dusty work environment). Liquid and solid radioactive, hazardous, and industrial waste may be generated, which will require proper handling, storage, and disposal.

2. Hazard category: Less Than Hazard Category 3 radiological

3. Radioactive waste managed at this facility: Routine contact-handled LLW is generated and staged at this facility

\section{RWMB documents/programs:}

a) Safety basis/hazard analysis:

- ECAR-999, "Hazard Categorization for CPP-1634 at the Material Security and Consolidation Complex"

b) Laboratory-wide:

- Form 435.39, "Waste Determination and Disposition Form (WDDF)"

- Form 435.42, "Radioactive Waste Inventory Sheet"

- Form 441.A34, "INL Radiological Control Required Surveys"

- LI-435, "Waste Management Routine Field Activities"

- LRD-15001, "Radiological Control Manual"

- LWP-13840, "Management of Issues, Observations, and Noteworthy Practices"

- LWP-14002, "Timeout and Stop Work Authority"

- LWP-15011, "Radioactive Material Areas and Radioactive Storage Areas"

- LWP-17000, "Waste Management"

- MCP-139, "Radiological Surveys"

- MCP-17000, "Waste Generator Services Waste Management"

- MCP-17500, "Waste Generator Services Certification of Waste Shipments to the Nevada Test Site" 
- PDD-17000, "Waste Management Program"

- PLN-114, "INL Emergency Plan/RCRA Contingency Plan"

- PLN-522, "Quality Assurance Program Plan for the Waste Management/Waste Certification Program"

c) Facility-specific:

- IAG-514, "INL Authorization Agreement for Understanding Between Battelle Energy Alliance (BEA) and CH2M-WGI (CWI) for the Turnover and Operation of CPP-609, CPP-651, CPP-653, CPP-661, CPP-1634, and CPP-1674"

- LI 1643-11-INTEC, "General Powder Processing."

LLW is managed at this facility. Table 3 presents the facility compliance information for Chapter IV, "Low-Level Waste Requirements."

Table 3. CPP-1634, Technology Development Facility, DOE Manual 435.1-1 low-level waste requirements and facility compliance information.

\begin{tabular}{|c|c|}
\hline \multicolumn{2}{|c|}{ Facility Name: CPP-1634, Technology Development Facility } \\
\hline Chapter IV, LLW Requirements & Facility Compliance Information \\
\hline $\begin{array}{l}\text { A. Definition of Low-Level Waste. Low-level radioactive waste is } \\
\text { radioactive waste that is not high-level radioactive waste, spent } \\
\text { nuclear fuel, transuranic waste, byproduct material (as defined in } \\
\text { section 11e.(2) of the Atomic Energy Act of 1954, as amended), or } \\
\text { naturally occurring radioactive material. } \\
\text { (From DOE G } 435.1-1 \text { Chapter IV: Low-level radioactive waste is } \\
\text { defined by what it is not. The guidance on definitions in Chapters II } \\
\text { and III should be consulted first for making a determination on how } \\
\text { to properly manage a suspect waste stream.) }\end{array}$ & $\begin{array}{l}\text { This requirement provides the criteria for } \\
\text { determining which DOE radioactive waste } \\
\text { is to be managed as LLW in accordance } \\
\text { with DOE Manual } 435.1-1 \text {, Chapter IV. } \\
\text { Radioactive waste managed at this facility } \\
\text { under the requirements of this chapter is } \\
\text { not managed under the requirements of } \\
\text { DOE Manual 435.1-1 Chapter II or } \\
\text { Chapter III. }\end{array}$ \\
\hline $\begin{array}{l}\text { B. Management of Specific Wastes. The following provide for } \\
\text { management of specific wastes as low-level waste in accordance } \\
\text { with the requirements in this Chapter: }\end{array}$ & See (1), (2), (3), and (4) below. \\
\hline $\begin{array}{l}\text { (1) Mixed Low-Level Waste. Low-level waste determined to contain } \\
\text { both source, special nuclear, or byproduct material subject to the } \\
\text { Atomic Energy Act of 1954, as amended, and a hazardous } \\
\text { component subject to the Resource Conservation and Recovery } \\
\text { Act (RCRA), as amended, shall be managed in accordance with } \\
\text { the requirements of RCRA and DOE O 435.1, Radioactive Waste } \\
\text { Management, and this Manual. }\end{array}$ & $\begin{array}{l}\text { NA; this facility does not manage } \\
\text { RCRA-regulated mixed LLW. }\end{array}$ \\
\hline $\begin{array}{l}\text { (2) TSCA-Regulated Waste. Low-level waste containing } \\
\text { polychlorinated biphenyls, asbestos, or other such regulated toxic } \\
\text { components shall be managed in accordance with requirements } \\
\text { derived from the Toxic Substances Control Act, as amended, } \\
\text { DOE O 435.1, Radioactive Waste Management, and this Manual. }\end{array}$ & $\begin{array}{l}\text { NA; this facility does not manage } \\
\text { TSCA-regulated waste. }\end{array}$ \\
\hline $\begin{array}{l}\text { (3) Accelerator-Produced Waste. Radioactive waste produced as a } \\
\text { result of operations of DOE accelerators is low-level waste and } \\
\text { shall be managed in accordance with DOE O 435.1, Radioactive } \\
\text { Waste Management, and this Manual, and all applicable Federal } \\
\text { or State requirements. }\end{array}$ & $\begin{array}{l}\text { NA; this facility does not manage } \\
\text { accelerator-produced waste. }\end{array}$ \\
\hline $\begin{array}{l}\text { (4) } 11 \text { e.(2) and Naturally Occurring Radioactive Material. Small } \\
\text { quantities of 11e.(2) byproduct material and naturally occurring } \\
\text { radioactive material may be managed as low-level waste } \\
\text { provided they can be managed to meet the requirements for low- } \\
\text { level waste disposal in Section IV.P of this Manual. }\end{array}$ & $\begin{array}{l}\text { NA; this facility does not manage } \\
\text { naturally occurring radioactive material. }\end{array}$ \\
\hline
\end{tabular}


Table 3. (continued).

\begin{tabular}{|c|c|}
\hline \multicolumn{2}{|c|}{ Facility Name: CPP-1634, Technology Development Facility } \\
\hline Chapter IV, LLW Requirements & Facility Compliance Information \\
\hline $\begin{array}{l}\text { C. Complex-Wide Low-Level Waste Management Program. A } \\
\text { complex-wide program and plan shall be developed as described } \\
\text { under Responsibilities, 2.B and 2.D, in Chapter I of this Manual. }\end{array}$ & $\begin{array}{l}\text { Not a facility-specific requirement. } \\
\text { DOE Manual 435.1-1 §I.2.B and } \S \text { I.2.D } \\
\text { apply to the Assistant Secretary for } \\
\text { Environmental Management and the } \\
\text { Deputy Assistant Secretary for Waste } \\
\text { Management, respectively. }\end{array}$ \\
\hline $\begin{array}{l}\text { D. Radioactive Waste Management Basis. Low-level waste facilities, } \\
\text { operations, and activities shall have a radioactive waste management } \\
\text { basis consisting of physical and administrative controls to ensure the } \\
\text { protection of workers, the public, and the environment. The } \\
\text { following specific waste management controls shall be part of the } \\
\text { radioactive waste management basis: }\end{array}$ & $\begin{array}{l}\text { The RWMB provides the regulatory } \\
\text { framework for management of radioactive } \\
\text { waste at INL. It specifically identifies } \\
\text { facility management and implementing } \\
\text { documents for the generation, storage, } \\
\text { treatment, and disposal of radiological } \\
\text { waste. }\end{array}$ \\
\hline $\begin{array}{l}\text { (1) Generators. The waste certification program. } \\
\text { From DOE G 435.1-1 Chapter IV: For a facility that generates } \\
\text { low-level waste, the radioactive waste management basis is to } \\
\text { include the program for certifying that waste meets the waste } \\
\text { acceptance requirements of the facility(ies) to which the waste } \\
\text { will be sent. }\end{array}$ & $\begin{array}{l}\text { See J. below for waste certification } \\
\text { program requirements. } \\
\text { ECAR-999 establishes this laboratory } \\
\text { facility as a Less Than Hazard Category } 3 \\
\text { facility. } \\
\text { LI } 1643-11 \text {-INTEC is the operating } \\
\text { procedure for these activities. }\end{array}$ \\
\hline $\begin{array}{l}\text { (2) Treatment Facilities. certification program. The waste acceptance } \\
\text { requirements and the waste [sic] } \\
\text { From DOE G 435.1-1 Chapter IV: Facilities that store or treat } \\
\text { low-level waste are to have approved waste acceptance } \\
\text { requirements (see DOE M 435.1-1, Section IV.G) prior to the } \\
\text { issuance of a radioactive waste management basis. } \\
\text { A facility that stores or treats waste also is generally expected to } \\
\text { have a waste certification program. Waste from these facilities } \\
\text { will have to be certified as meeting the waste acceptance } \\
\text { requirements of the facility to which it will be transferred, and } \\
\text { the facilities have the potential for generating radioactive waste } \\
\text { (e.g., secondary processing streams from treatment, monitoring } \\
\text { and sampling, radioactive release cleanup). Consequently, } \\
\text { storage and treatment facilities should also have an approved } \\
\text { waste certification program as part of their radioactive waste } \\
\text { management basis. } \\
\text { As part of the radioactive waste management basis, site personnel } \\
\text { needs to implement a system or process for tracking the waste } \\
\text { inventory at a storage, treatment, or disposal facility. }\end{array}$ & NA; waste is not treated at this facility. \\
\hline $\begin{array}{l}\text { (3) Storage Facilities. The waste acceptance requirements and the } \\
\text { waste certification program. } \\
\text { From DOE G 435.1-1 Chapter IV: Facilities that store or treat } \\
\text { low-level waste are to have approved waste acceptance } \\
\text { requirements (see DOE M 435.1-1, Section IV.G) prior to the } \\
\text { issuance of a radioactive waste management basis. } \\
\text { A facility that stores or treats waste also is generally expected to } \\
\text { have a waste certification program. Waste from these facilities } \\
\text { will have to be certified as meeting the waste acceptance } \\
\text { requirements of the facility to which it will be transferred, and }\end{array}$ & $\begin{array}{l}\text { NA; this facility stages waste in } \\
\text { accordance with N.(7) to facilitate } \\
\text { treatment or disposal. }\end{array}$ \\
\hline
\end{tabular}


Table 3. (continued).

\begin{tabular}{|c|c|}
\hline \multicolumn{2}{|c|}{ Facility Name: CPP-1634, Technology Development Facility } \\
\hline Chapter IV, LLW Requirements & Facility Compliance Information \\
\hline $\begin{array}{l}\text { the facilities have the potential for generating radioactive waste } \\
\text { (e.g., secondary processing streams from treatment, monitoring } \\
\text { and sampling, radioactive release cleanup). Consequently, } \\
\text { storage and treatment facilities should also have an approved } \\
\text { waste certification program as part of their radioactive waste } \\
\text { management basis. }\end{array}$ & \\
\hline $\begin{array}{l}\text { As part of the radioactive waste management basis, site personnel } \\
\text { needs to implement a system or process for tracking the waste } \\
\text { inventory at a storage, treatment, or disposal facility. }\end{array}$ & \\
\hline $\begin{array}{l}\text { (4) Disposal Facilities. The performance assessment, composite } \\
\text { analysis, disposal authorization statement, closure plan, waste } \\
\text { acceptance requirements, and monitoring plan. }\end{array}$ & NA; this facility is not a disposal facility. \\
\hline $\begin{array}{l}\text { E. Contingency Actions. The following requirements are in addition to } \\
\text { those in Chapter I of this Manual [DOE M 435.1-1 §I.1.E(5)]. }\end{array}$ & $\begin{array}{l}\text { DOE Manual } 435.1-1 \text { II.1.E(5) addresses } \\
\text { the sitewide emergency management } \\
\text { system. The INL plan is provided in } \\
\text { PLN-114. }\end{array}$ \\
\hline $\begin{array}{l}\text { (1) Contingency Storage. For off-normal or emergency situations } \\
\text { involving high activity or high hazard liquid low-level waste } \\
\text { storage or treatment, spare capacity with adequate capabilities } \\
\text { shall be maintained to receive the largest volume of liquid } \\
\text { contained in any one storage tank or treatment facility. Tanks or } \\
\text { other facilities that are designated low-level waste contingency } \\
\text { storage shall be maintained in an operational condition when } \\
\text { waste is present and shall meet the requirements of DOE O } \\
\text { 435.1, Radioactive Waste Management, and this Manual. }\end{array}$ & $\begin{array}{l}\text { NA; this facility does not store liquid } \\
\text { LLW. }\end{array}$ \\
\hline $\begin{array}{l}\text { From DOE G 435.1-1 Chapter IV: Compliance with these } \\
\text { requirements is demonstrated if adequate spare capacity and } \\
\text { transfer equipment exists for emergency transfers of all high } \\
\text { activity and high hazard liquid low-level waste. In addition, the } \\
\text { capability to perform emergency transfers is demonstrated by } \\
\text { having waste transfer routings identified, operational procedures } \\
\text { to direct transfers, staff trained to the procedures, and records } \\
\text { showing that the spare capacity and transfer capability are kept in } \\
\text { operating condition. }\end{array}$ & \\
\hline $\begin{array}{l}\text { (2) Transfer Equipment. Pipelines and auxiliary facilities necessary } \\
\text { for the transfer of high activity or high hazard liquid low-level } \\
\text { waste to contingency storage shall be maintained in an } \\
\text { operational condition when waste is present and shall meet the } \\
\text { requirements of DOE O 435.1, Radioactive Waste Management, } \\
\text { and this Manual. }\end{array}$ & $\begin{array}{l}\text { NA; this facility does not store or treat } \\
\text { liquid LLW. }\end{array}$ \\
\hline $\begin{array}{l}\text { From DOE G 435.1-1 Chapter IV: Compliance with these } \\
\text { requirements is demonstrated if adequate spare capacity and } \\
\text { transfer equipment exists for emergency transfers of all high } \\
\text { activity and high hazard liquid low-level waste. In addition, the } \\
\text { capability to perform emergency transfers is demonstrated by } \\
\text { having waste transfer routings identified, operational procedures } \\
\text { to direct transfers, staff trained to the procedures, and records } \\
\text { showing that the spare capacity and transfer capability are kept in } \\
\text { operating condition. }\end{array}$ & \\
\hline F. Corrective Actions. I of this Manual. The following requirements & The INL-wide procedure addressing \\
\hline
\end{tabular}


Table 3. (continued).

\begin{tabular}{|c|c|}
\hline \multicolumn{2}{|c|}{ Facility Name: CPP-1634, Technology Development Facility } \\
\hline Chapter IV, LLW Requirements & Facility Compliance Information \\
\hline are in addition to those in Chapter [sic] & \multirow{3}{*}{$\begin{array}{l}\text { problem identification as required by } \\
\text { DOE Manual } 435.1-1 \text { §I.2.G.(1) is } \\
\text { LWP-13840, which implements the } \\
\text { laboratory's corrective action system. } \\
\text { The INL-wide procedure addressing } \\
\text { shutdown or curtailment of activities as } \\
\text { required by DOE Manual } 435.1-1 \\
\text { §I.2.G.(2) is LWP-14002. }\end{array}$} \\
\hline $\begin{array}{l}\text { From DOE G } 435.1-1 \text { Chapter IV: Compliance with DOE M 435.1-1 } \\
\text { §I.2.G.(1) is demonstrated by records showing what corrective } \\
\text { actions were taken to remedy situations in the radioactive waste }\end{array}$ & \\
\hline $\begin{array}{l}\text { management system. } \\
\text { Compliance with DOE M 435.1-1 §I.2.G.(2) is demonstrated by } \\
\text { having the necessary procedures, mechanisms, and training in place } \\
\text { to effect shutdown or curtailment of activities which pose an } \\
\text { imminent danger or other serious hazard to workers or the public, or } \\
\text { are not protective of the environment. }\end{array}$ & \\
\hline $\begin{array}{l}\text { (1) Order Compliance. Corrective actions shall be implemented } \\
\text { whenever necessary to ensure the requirements of DOE O 435.1, } \\
\text { Radioactive Waste Management, and this Manual are met. }\end{array}$ & \multirow[t]{3}{*}{ See F. above. } \\
\hline $\begin{array}{l}\text { From DOE G 435.1-1 Chapter IV: If a facility or activity can be } \\
\text { allowed to operate while a noncompliant or hazardous condition } \\
\text { exists, the allowance and any associated limitations must be } \\
\text { defined as part of the facility or activity's radioactive waste } \\
\text { management basis, identified as a configuration controlled item } \\
\text { in a configuration management plan or included in a revision or } \\
\text { modification to an operating procedure or similar controlled } \\
\text { documentation. }\end{array}$ & \\
\hline $\begin{array}{l}\text { Compliance with this requirement is demonstrated if a corrective } \\
\text { action system addresses noncompliant or hazardous situations } \\
\text { involving low-level waste management facilities in a systematic } \\
\text { fashion, and allows identification of problems by all personnel. }\end{array}$ & \\
\hline $\begin{array}{l}\text { (2) Operations Curtailment. Operations shall be curtailed or facilities } \\
\text { shut down for failure to establish, maintain, or operate consistent } \\
\text { with an approved radioactive waste management basis. }\end{array}$ & \multirow{2}{*}{$\begin{array}{l}\text { The approved RWMB establishes the } \\
\text { current compliance status at each } \\
\text { radioactive waste management facility. } \\
\text { Facility assessments are scheduled to } \\
\text { ensure waste management activities are } \\
\text { conducted in accordance with the } \\
\text { approved RWMB. }\end{array}$} \\
\hline $\begin{array}{l}\text { From DOE G 435.1-1 Chapter IV: Compliance with this } \\
\text { requirement is demonstrated with a documented system of } \\
\text { routine assessments to determine whether waste management } \\
\text { activities and facilities are operating in accordance with an } \\
\text { approved radioactive waste management basis that provides for } \\
\text { graded limitations that can be placed on activities and operations } \\
\text { that do not have, or are operating outside of, an approved } \\
\text { radioactive waste management basis, including shutdown of the } \\
\text { facility. }\end{array}$ & \\
\hline $\begin{array}{l}\text { G. Waste Acceptance. The following requirements are in addition to } \\
\text { those in Chapter I of this Manual [DOE M 435.1-1 §I.2.F(6)]. }\end{array}$ & $\begin{array}{l}\text { DOE Manual 435.1-1 §I.2.F(6) applies to } \\
\text { field element managers. }\end{array}$ \\
\hline $\begin{array}{l}\text { (1) Technical and Administrative. Waste acceptance requirements } \\
\text { for all low-level waste storage, treatment, or disposal facilities, } \\
\text { operations, and activities shall specify, at a minimum, the } \\
\text { following: }\end{array}$ & \multirow[t]{2}{*}{$\begin{array}{l}\text { NA; this facility does not accept LLW } \\
\text { from other facilities. }\end{array}$} \\
\hline $\begin{array}{l}\text { From DOE G 435.1-1 Chapter IV: Compliance with these waste } \\
\text { acceptance requirements is demonstrated if they are documented, } \\
\text { contain clear and precise criteria specifying the radionuclide } \\
\text { limits in the form of contents or concentrations that can be } \\
\text { accepted, the limitations and prohibitions on waste forms and } \\
\text { packages that can be received, and the limits, prohibitions, or }\end{array}$ & \\
\hline
\end{tabular}


Table 3. (continued).

\begin{tabular}{|c|c|}
\hline \multicolumn{2}{|c|}{ Facility Name: CPP-1634, Technology Development Facility } \\
\hline Chapter IV, LLW Requirements & Facility Compliance Information \\
\hline $\begin{array}{l}\text { instructions concerning any other technical information so that } \\
\text { the waste is compatible with the safety basis of the facility, and } \\
\text { which will result in acceptable waste at subsequent steps in } \\
\text { managing the low-level waste. }\end{array}$ & \\
\hline $\begin{array}{l}\text { (a) Allowable activities and/or concentrations of specific } \\
\text { radionuclides. }\end{array}$ & See (1) above. \\
\hline $\begin{array}{l}\text { (b) Acceptable waste form and/or container requirements that } \\
\text { ensure the chemical and physical stability of waste under } \\
\text { conditions that might be encountered during transportation, } \\
\text { storage, treatment, or disposal. }\end{array}$ & See (1) above. \\
\hline $\begin{array}{l}\text { (c) Restrictions or prohibitions on waste, materials, or containers } \\
\text { that may adversely affect waste handlers or compromise } \\
\text { facility or waste container performance. }\end{array}$ & See (1) above. \\
\hline $\begin{array}{l}\text { (d) The following are additional waste acceptance requirements } \\
\text { that shall be specified in low-level waste disposal facility } \\
\text { waste acceptance requirements: }\end{array}$ & See (1) above. \\
\hline $\begin{array}{l}1 \text { Low-level waste must contribute to and not detract from } \\
\text { achieving long-term stability of the facility, minimizing the } \\
\text { need for long-term active maintenance, minimizing } \\
\text { subsidence, and minimizing contact of water with waste. } \\
\text { Void spaces within the waste and, if containers are used, } \\
\text { between the waste and its container shall be reduced to the } \\
\text { extent practical. }\end{array}$ & See (1) above. \\
\hline $\begin{array}{l}2 \text { Liquid low-level waste or low-level waste containing free } \\
\text { liquid must be converted into a form that contains as little } \\
\text { freestanding liquid as is reasonably achievable, but in no } \\
\text { case shall the liquid exceed } 1 \text { percent of the waste volume } \\
\text { when the low-level waste is in a disposal container, or } 0.5 \\
\text { percent of the waste volume after it is processed to a stable } \\
\text { form. }\end{array}$ & See (1) above. \\
\hline $\begin{array}{l}3 \text { Low-level waste must not be readily capable of detonation } \\
\text { or of explosive decomposition or reaction at anticipated } \\
\text { pressures and temperatures, or of explosive reaction with } \\
\text { water. Pyrophoric materials contained in waste shall be } \\
\text { treated, prepared, and packaged to be nonflammable. }\end{array}$ & See (1) above. \\
\hline $\begin{array}{l}4 \text { Low-level waste must not contain, or be capable of } \\
\text { generating by radiolysis or biodegradation, quantities of } \\
\text { toxic gases, vapors, or fumes harmful to the public or } \\
\text { workers or disposal facility personnel, or harmful to the } \\
\text { long-term structural stability of the disposal site. }\end{array}$ & See (1) above. \\
\hline $\begin{array}{l}5 \text { Low-level waste in a gaseous form must be packaged such } \\
\text { that the pressure does not exceed } 1.5 \text { atmospheres absolute } \\
\text { at } 20 \text { C. [sic] }\end{array}$ & See (1) above. \\
\hline $\begin{array}{l}\text { (e) The basis, procedures, and levels of authority required for } \\
\text { granting exceptions to the waste acceptance requirements, } \\
\text { which shall be contained in each facility's waste acceptance } \\
\text { documentation. Each exception request shall be documented, } \\
\text { including its disposition as approved or not approved. } \\
\text { From DOE G 435.1-1 Chapter IV: Waste acceptance }\end{array}$ & See (1) above. \\
\hline
\end{tabular}


Table 3. (continued).

\begin{tabular}{|c|c|}
\hline \multicolumn{2}{|c|}{ Facility Name: CPP-1634, Technology Development Facility } \\
\hline Chapter IV, LLW Requirements & Facility Compliance Information \\
\hline $\begin{array}{l}\text { requirements are acceptable if they are documented and } \\
\text { contain a clear description of the procedure and bases for } \\
\text { obtaining an exception or deviation to the acceptance criteria } \\
\text { for low-level waste to be received at the facility. }\end{array}$ & \\
\hline $\begin{array}{l}\text { (2) Evaluation and Acceptance. The receiving facility shall evaluate } \\
\text { waste for acceptance, including confirmation that the technical } \\
\text { and administrative requirements have been met. A process for the } \\
\text { disposition of non-conforming wastes shall be established. }\end{array}$ & See (1) above. \\
\hline $\begin{array}{l}\text { From DOE G 435.1-1 Chapter IV: Compliance with the waste } \\
\text { acceptance requirements for a low-level waste management } \\
\text { facility is demonstrated if they include a process for evaluation } \\
\text { and acceptance of incoming waste to ensure the acceptance } \\
\text { criteria of the facility receiving the waste are met that includes } \\
\text { one of or a combination of: (1) testing, sampling, and analysis of } \\
\text { representative samples of waste upon receipt; (2) testing, } \\
\text { sampling, and analysis of split samples of waste taken at the } \\
\text { generator site; (3) evaluation of testing, sampling, and analysis of } \\
\text { data provided by the generator, or (4) audits, reviews, } \\
\text { surveillance, or observations of generator waste certification } \\
\text { programs and characterization activities. Additionally, acceptable } \\
\text { waste acceptance requirements for a storage, treatment or } \\
\text { disposal facility will have documented procedures and actions to } \\
\text { be taken if a waste that does not conform to the waste acceptance } \\
\text { criteria is received at the facility. }\end{array}$ & \\
\hline $\begin{array}{l}\text { H. Waste Generation Planning. The following requirements are in } \\
\text { addition to those in Chapter I of this Manual [DOE M 435.1-1 } \\
\text { §I.2.F(7)]. }\end{array}$ & $\begin{array}{l}\text { DOE Manual 435.1-1 §I.2.F(7) applies to } \\
\text { field element managers. }\end{array}$ \\
\hline $\begin{array}{l}\text { (1) Life-Cycle Planning. Prior to waste generation, planning shall be } \\
\text { performed to address the entire life cycle for all low-level waste } \\
\text { streams. }\end{array}$ & $\begin{array}{l}\text { PDD-17000 and LWP- } 17000 \text { provide } \\
\text { direction to the waste generators for waste } \\
\text { generation planning to address the entire }\end{array}$ \\
\hline $\begin{array}{l}\text { From DOE G 435.1-1 Chapter IV: Compliance with this planning } \\
\text { requirement is demonstrated by the individual sites establishing a } \\
\text { process for evaluating the life-cycle of low-level waste prior to } \\
\text { its generation, including the identification of low-level wastes } \\
\text { with no path to disposal and appropriate records justifying the } \\
\text { newly generated low-level waste stream(s), and site personnel } \\
\text { possessing planning information showing the location(s) where } \\
\text { low-level waste will be stored, treated, and/or disposed along } \\
\text { with a confirmation that the personnel managing the facilities } \\
\text { agree that the low-level waste may be managed at those facilities. }\end{array}$ & life cycle. \\
\hline $\begin{array}{l}\text { (2) Waste with No Identified Path to Disposal. Low-level waste } \\
\text { streams with no identified path to disposal shall be generated } \\
\text { only in accordance with approved conditions which, at a } \\
\text { minimum, shall address: }\end{array}$ & $\begin{array}{l}\text { This facility does not generate radioactive } \\
\text { waste that does not have an identified path } \\
\text { to disposal. }\end{array}$ \\
\hline (a) Programmatic need to generate the waste; & See (2) above. \\
\hline $\begin{array}{l}\text { (b) Characteristics and issues preventing the disposal of the } \\
\text { waste; }\end{array}$ & See (2) above. \\
\hline (c) Safe storage of the waste until disposal can be achieved; and & See (2) above. \\
\hline (d) Activities and plans for achieving final disposal of the waste. & See (2) above. \\
\hline
\end{tabular}


Table 3. (continued).

\begin{tabular}{|c|c|}
\hline \multicolumn{2}{|c|}{ Facility Name: CPP-1634, Technology Development Facility } \\
\hline Chapter IV, LLW Requirements & Facility Compliance Information \\
\hline $\begin{array}{l}\text { I. Waste Characterization. Low-level waste shall be characterized } \\
\text { using direct or indirect methods, and the characterization } \\
\text { documented in sufficient detail to ensure safe management and } \\
\text { compliance with the waste acceptance requirements of the facility } \\
\text { receiving the waste. } \\
\text { From DOE G 435.1-1 Chapter IV: Compliance with this requirement } \\
\text { is demonstrated by a program for documenting and the existence of } \\
\text { records that document the process for acquiring and verifying the } \\
\text { validity of low-level waste characterization data acquired through } \\
\text { the use of direct or indirect methods. }\end{array}$ & $\begin{array}{l}\text { MCP- } 17000 \S 4 \text { specifies the requirements } \\
\text { for preparing an IWTS profile that } \\
\text { captures waste characterization } \\
\text { information. }\end{array}$ \\
\hline $\begin{array}{l}\text { (1) Data Quality Objectives. The data quality objectives process, or a } \\
\text { comparable process, shall be used for identifying characterization } \\
\text { parameters and acceptable uncertainty in characterization data. } \\
\text { From DOE G 435.1-1 Chapter IV: Compliance with this } \\
\text { requirement is demonstrated by the documented use of a data } \\
\text { quality objectives or a comparable process for determining the } \\
\text { type, quantity, and quality of characterization data needed to } \\
\text { safely manage low-level waste. }\end{array}$ & $\begin{array}{l}\text { Radioactive waste management facilities } \\
\text { characterize waste in accordance with the } \\
\text { requirements of the receiving storage, } \\
\text { treatment, or disposal facility. The } \\
\text { documented use of a data quality } \\
\text { objectives process, or comparable process, } \\
\text { was not identified for this facility. }\end{array}$ \\
\hline $\begin{array}{l}\text { (2) Minimum Waste Characterization. Characterization data shall, at } \\
\text { a minimum, include the following information relevant to the } \\
\text { management of the waste: } \\
\text { From DOE G } 435.1-1 \text { Chapter IV: Compliance with this } \\
\text { requirement is demonstrated by the existence of a program or } \\
\text { procedure for determining and records that document } \\
\text { characterization of low-level waste consistent with the minimum } \\
\text { characterization data requirements. }\end{array}$ & $\begin{array}{l}\text { MCP- } 17000 \S 4 \text { specifies the requirements } \\
\text { for preparing an IWTS profile that } \\
\text { captures waste characterization } \\
\text { information. }\end{array}$ \\
\hline (a) Physical and chemical characteristics; & See (2) above. \\
\hline $\begin{array}{l}\text { (b) Volume, including the waste and any stabilization or } \\
\text { absorbent media; }\end{array}$ & See (2) above. \\
\hline (c) Weight of the container and contents; & See (2) above. \\
\hline $\begin{array}{l}\text { (d) Identities, activities, and concentrations of major } \\
\text { radionuclides; }\end{array}$ & See (2) above. \\
\hline (e) Characterization date; & See (2) above. \\
\hline (f) Generating source; and & See (2) above. \\
\hline $\begin{array}{l}\text { (g) Any other information which may be needed to prepare and } \\
\text { maintain the disposal facility performance assessment, or } \\
\text { demonstrate compliance with applicable performance } \\
\text { objectives. }\end{array}$ & See (2) above. \\
\hline $\begin{array}{l}\text { J. Waste Certification. A waste certification program shall be } \\
\text { developed, documented, and implemented to ensure that the waste } \\
\text { acceptance requirements of facilities receiving low-level waste for } \\
\text { storage, treatment, and disposal are met. } \\
\text { From DOE G 435.1-1 Chapter IV: Compliance with the } \\
\text { development and documentation portion of the certification } \\
\text { requirement is demonstrated by a waste certification plan that } \\
\text { identifies the organizations involved, assigns responsibilities for } \\
\text { implementing the program, and describes or references the quality } \\
\text { assurance, training, procurement controls, records management, and }\end{array}$ & $\begin{array}{l}\text { MCP- } 17000 \S 4 \text { specifies the requirements } \\
\text { for preparing an IWTS profile that } \\
\text { captures waste certification information. } \\
\text { MCP-17500 provides the Waste Generator } \\
\text { Services Waste Certification Program for } \\
\text { LLW to be shipped to NNSS. } \\
\text { Container procurement is addressed in } \\
\text { MCP-17000 } \$ 4.6 . \\
\text { Waste certification is performed and }\end{array}$ \\
\hline
\end{tabular}


Table 3. (continued).

\begin{tabular}{|c|c|}
\hline \multicolumn{2}{|c|}{ Facility Name: CPP-1634, Technology Development Facility } \\
\hline Chapter IV, LLW Requirements & Facility Compliance Information \\
\hline $\begin{array}{l}\text { procedures to be used by the program. Acceptable performance for } \\
\text { implementing the program is demonstrated when appropriate } \\
\text { personnel are trained and follow the procedures that govern their }\end{array}$ & $\begin{array}{l}\text { tracked using IWTS. Documentation of } \\
\text { the IWTS Program is only available } \\
\text { electronically. }\end{array}$ \\
\hline $\begin{array}{l}\text { part of the waste certification. Additionally, acceptable performance } \\
\text { is demonstrated if the waste certification plan and procedures are } \\
\text { current and controlled in accordance with a document controls } \\
\text { program, and records related to certification (e.g., certification } \\
\text { statements, training records, procurement records, characterization } \\
\text { records, container records) are generated and managed in accordance } \\
\text { with the established site program. }\end{array}$ & $\begin{array}{l}\text { PLN-522 requires waste technical } \\
\text { specialists and waste disposition } \\
\text { specialists to complete the appropriate } \\
\text { training/qualification before being granted } \\
\text { approval authority for profiles within the } \\
\text { IWTS Program. The waste certification } \\
\text { official, alternate waste certification } \\
\text { official, and NNSS packaging certifiers } \\
\text { must complete the appropriate } \\
\text { training/qualifications to disposition waste } \\
\text { to NNSS. }\end{array}$ \\
\hline $\begin{array}{l}\text { (1) Certification Program. The waste certification program shall } \\
\text { designate the officials who have the authority to certify and } \\
\text { release waste for shipment; and specify what documentation is } \\
\text { required for waste generation, characterization, shipment, and } \\
\text { certification. The program shall provide requirements for } \\
\text { auditability, retrievability, and storage of required documentation } \\
\text { and specify the records retention period. }\end{array}$ & See J. above. \\
\hline $\begin{array}{l}\text { From DOE G 435.1-1 Chapter IV: Compliance with this } \\
\text { requirement is demonstrated by a program or procedure for } \\
\text { record keeping and records showing that low-level waste is } \\
\text { certified as having met the waste acceptance criteria of the } \\
\text { facility to which it was transferred and that the certification } \\
\text { statement is supported by additional records regarding the waste } \\
\text { source, characterization, and container. }\end{array}$ & \\
\hline $\begin{array}{l}\text { (2) Certification before Transfer. Low-level waste shall be certified } \\
\text { as meeting waste acceptance requirements before it is transferred } \\
\text { to the facility receiving the waste. }\end{array}$ & See J. above. \\
\hline $\begin{array}{l}\text { From DOE G 435.1-1 Chapter IV: Compliance with this } \\
\text { requirement is demonstrated by the presence of a certification } \\
\text { program which includes procedures requiring a signed } \\
\text { certification statement prior to the release of waste for transfer, } \\
\text { and by dated records showing that waste was certified before } \\
\text { being transferred. }\end{array}$ & \\
\hline $\begin{array}{l}\text { (3) Maintaining Certification. Low-level waste that has been } \\
\text { certified as meeting the waste acceptance requirements for } \\
\text { transfer to a storage, treatment, or disposal facility shall be } \\
\text { managed in a manner that maintains its certification status. }\end{array}$ & See J. above. \\
\hline $\begin{array}{l}\text { From DOE G 435.1-1 Chapter IV: Compliance with this } \\
\text { requirement is demonstrated by a program or procedure } \\
\text { reflecting this requirement is present and site personnel are able } \\
\text { to show that the storage of low-level waste containers is in a } \\
\text { facility or manner where the containers would not be damaged by } \\
\text { normal weather events, and cannot be accessed by unauthorized } \\
\text { personnel. Further, each container can be traced to its } \\
\text { certification and the information supporting that certification. }\end{array}$ & \\
\hline K. Waste Transfer. A documented process shall be established and & MCP-17000 specifies the requirements for \\
\hline
\end{tabular}


Table 3. (continued).

\begin{tabular}{|c|c|}
\hline \multicolumn{2}{|c|}{ Facility Name: CPP-1634, Technology Development Facility } \\
\hline Chapter IV, LLW Requirements & Facility Compliance Information \\
\hline $\begin{array}{l}\text { implemented for transferring responsibility for management of low- } \\
\text { level waste and for ensuring availability of relevant data. The } \\
\text { following requirements are in addition to those in Chapter I of this } \\
\text { Manual. }\end{array}$ & $\begin{array}{l}\text { preparing an IWTS profile that captures } \\
\text { waste certification data, transfer } \\
\text { information, and associated } \\
\text { authorizations. }\end{array}$ \\
\hline $\begin{array}{l}\text { From DOE G } 435.1-1 \text { Chapter IV: Compliance with this requirement } \\
\text { is demonstrated if facilities have procedures for the receipt of waste } \\
\text { and the transfer of waste, as appropriate, which address the } \\
\text { acquisition of waste and container data and the transfer of } \\
\text { ownership, respectively. Further evidence of acceptable performance } \\
\text { is facility records showing that data on the waste containers is } \\
\text { available and accurate, and that documented transfer of } \\
\text { responsibility occurs. }\end{array}$ & $\begin{array}{l}\text { MCP-17500 provides the Waste Generator } \\
\text { Services Waste Certification Program for } \\
\text { LLW to be shipped to NNSS. }\end{array}$ \\
\hline $\begin{array}{l}\text { (1) Authorization. Low-level waste shall not be transferred to a } \\
\text { storage, treatment, or disposal facility until personnel responsible } \\
\text { for the facility receiving the waste authorize the transfer. }\end{array}$ & See K. above. \\
\hline $\begin{array}{l}\text { From DOE G 435.1-1 Chapter IV: Compliance with this } \\
\text { requirement is demonstrated by sites having procedures that } \\
\text { require a confirmation of authorization before releasing waste for } \\
\text { transfer, and records showing that transfers are made in } \\
\text { accordance with written authorizations. }\end{array}$ & \\
\hline $\begin{array}{l}\text { (2) Data. Waste characterization data, container information, and } \\
\text { generation, storage, treatment, and transportation information for } \\
\text { low-level waste shall be transferred with or be traceable to the } \\
\text { waste. }\end{array}$ & See K. above. \\
\hline $\begin{array}{l}\text { From DOE G } 435.1-1 \text { Chapter IV: Compliance with this } \\
\text { requirement is demonstrated if there are procedures requiring that } \\
\text { characterization and container data be provided and maintained } \\
\text { for each low-level waste transfer and documented records of } \\
\text { transfers show that the information is being provided. }\end{array}$ & \\
\hline $\begin{array}{l}\text { L. Packaging and Transportation. The following requirements are in } \\
\text { addition to those in Chapter I of this Manual [DOE M 435.1-1 } \\
\text { §I.1.E(11)]. }\end{array}$ & $\begin{array}{l}\text { DOE Manual 435.1-1 §I.1.E(11) applies } \\
\text { to field element managers. }\end{array}$ \\
\hline $\begin{array}{l}\text { (1) Packaging. If containers are used: } \\
\text { From DOE G 435.1-1 Chapter IV: Compliance with the } \\
\text { packaging requirement is demonstrated by: (1) procedures which } \\
\text { document proper packaging protocols; and (2) no trends of } \\
\text { routine repackaging of low-level waste that is packaged after } \\
\text { issuance of DOE O } 435.1 \text {. Successful performance of this } \\
\text { requirement is also demonstrated by a record of containers for } \\
\text { which failure has not routinely occurred under management } \\
\text { conditions. It is recognized that there may be failed containers for } \\
\text { waste previously placed in storage. For those containers, the goal } \\
\text { is to only have to repackage the waste one time after it is } \\
\text { retrieved and characterized. Further, acceptable performance is } \\
\text { demonstrated by containers of waste having marking and labeling } \\
\text { that allows correlation with waste characterization data and } \\
\text { container information. }\end{array}$ & $\begin{array}{l}\text { MCP-17000 } \$ 4 \text { addresses packaging } \\
\text { requirements. }\end{array}$ \\
\hline $\begin{array}{l}\text { (a) Low-level waste shall be packaged in a manner that provides } \\
\text { containment and protection for the duration of the anticipated }\end{array}$ & See (1) above. \\
\hline
\end{tabular}


Table 3. (continued).

\begin{tabular}{|c|c|}
\hline \multicolumn{2}{|c|}{ Facility Name: CPP-1634, Technology Development Facility } \\
\hline Chapter IV, LLW Requirements & Facility Compliance Information \\
\hline $\begin{array}{l}\text { storage period and until disposal is achieved or until the waste } \\
\text { has been removed from the container. }\end{array}$ & \\
\hline $\begin{array}{l}\text { (b) When waste is packaged, vents or other measures shall be } \\
\text { provided if the potential exists for pressurizing or generating } \\
\text { flammable or explosive concentrations of gases within the } \\
\text { waste container. }\end{array}$ & See (1) above. \\
\hline $\begin{array}{l}\text { (c) Containers of low-level waste shall be marked such that their } \\
\text { contents can be identified. }\end{array}$ & See (1) above. \\
\hline $\begin{array}{l}\text { (2) Transportation. To the extent practical, the volume of waste and } \\
\text { number of low-level waste shipments shall be minimized. } \\
\text { From DOE G 435.1-1 Chapter IV: Compliance with this } \\
\text { requirement can be demonstrated by a combination of site } \\
\text { procedures directing the efficient use of waste container capacity }\end{array}$ & $\begin{array}{l}\text { MCP- } 17000 \S 4 \text { addresses transportation. } \\
\text { The waste disposition specialist } \\
\text { coordinates with packaging and } \\
\text { transportation personnel for waste shipped } \\
\text { offsite from this facility. }\end{array}$ \\
\hline $\begin{array}{l}\text { and documentation showing that low-level waste shipments are } \\
\text { systematically planned and optimized to the extent practical. }\end{array}$ & $\begin{array}{l}\text { Waste is shipped directly to NNSS from } \\
\text { this facility. MCP-17500 specifies waste } \\
\text { certification official and waste disposition } \\
\text { specialist responsibilities and coordination } \\
\text { with packaging and transportation } \\
\text { personnel. }\end{array}$ \\
\hline $\begin{array}{l}\text { M. Site Evaluation and Facility Design. The following requirements are } \\
\text { in addition to those in Chapter I of this Manual. }\end{array}$ & $\begin{array}{l}\text { NA; this requirement addresses new } \\
\text { radioactive waste management facilities. }\end{array}$ \\
\hline $\begin{array}{l}\text { (1) Site Evaluation. Proposed locations for low-level waste facilities } \\
\text { shall be evaluated to identify relevant features that should be } \\
\text { avoided or must be considered in facility design and analyses. }\end{array}$ & See M. above. \\
\hline $\begin{array}{l}\text { (a) Each site proposed for a new low-level waste facility or } \\
\text { expansion of an existing low-level waste facility shall be } \\
\text { evaluated considering environmental characteristics, } \\
\text { geotechnical characteristics, and human activities, including } \\
\text { for a low-level waste disposal facility, the capability of the } \\
\text { site to demonstrate, at a minimum, whether it is: }\end{array}$ & See M. above. \\
\hline $\begin{array}{l}1 \text { Located to accommodate the projected volume of waste to } \\
\text { be received; }\end{array}$ & See M. above. \\
\hline $\begin{array}{l}2 \text { Located in a flood plain, a tectonically active area, or in the } \\
\text { zone of water table fluctuation; and }\end{array}$ & See M. above. \\
\hline $\begin{array}{l}3 \text { Located where radionuclide migration pathways are } \\
\text { predictable and erosion and surface runoff can be } \\
\text { controlled. }\end{array}$ & See M. above. \\
\hline $\begin{array}{l}\text { (b) Proposed sites with environmental characteristics, } \\
\text { geotechnical characteristics, and human activities for which } \\
\text { adequate protection cannot be provided through facility } \\
\text { design shall be deemed unsuitable for the location of the } \\
\text { facility. }\end{array}$ & See M. above. \\
\hline $\begin{array}{l}\text { (c) Low-level waste disposal facilities shall be sited to achieve } \\
\text { long-term stability and to minimize, to the extent practical, } \\
\text { the need for active maintenance following final closure. }\end{array}$ & See M. above. \\
\hline $\begin{array}{l}\text { (2) Low-Level Waste Treatment and Storage Facility Design. The } \\
\text { following facility requirements and general design criteria, at a } \\
\text { minimum, apply: }\end{array}$ & See M. above. \\
\hline
\end{tabular}


Table 3. (continued).

\begin{tabular}{|c|c|}
\hline \multicolumn{2}{|c|}{ Facility Name: CPP-1634, Technology Development Facility } \\
\hline Chapter IV, LLW Requirements & Facility Compliance Information \\
\hline $\begin{array}{l}\text { (a) Confinement. Low-level waste systems and components shall } \\
\text { be designed to maintain waste confinement. }\end{array}$ & See M. above. \\
\hline (b) Ventilation. & See M. above. \\
\hline $\begin{array}{l}1 \text { Design of low-level waste treatment and storage facilities } \\
\text { shall include ventilation, if applicable, through an } \\
\text { appropriate filtration system to maintain the release of } \\
\text { radioactive material in airborne effluents within the } \\
\text { requirements and guidelines specified in applicable } \\
\text { requirements. }\end{array}$ & See M. above. \\
\hline $\begin{array}{l}2 \text { When conditions exist for generating gases in flammable or } \\
\text { explosive concentrations, ventilation systems or other } \\
\text { measures shall be provided to keep the gases in a non- } \\
\text { flammable and nonexplosive condition. Where } \\
\text { concentrations of explosive or flammable gases are } \\
\text { expected to approach the lower flammability limit, } \\
\text { measures shall be taken to prevent deflagration or } \\
\text { detonation. }\end{array}$ & See M. above. \\
\hline $\begin{array}{l}\text { (c) Consideration of Decontamination and Decommissioning. } \\
\text { Areas in new and modifications to existing low-level waste } \\
\text { management facilities that are subject to contamination with } \\
\text { radioactive or other hazardous materials shall be designed to } \\
\text { facilitate decontamination. For such facilities a proposed } \\
\text { decommissioning method or a conversion method leading to } \\
\text { reuse shall be described. }\end{array}$ & See M. above. \\
\hline $\begin{array}{l}\text { (d) Instrumentation and Control Systems. Engineering controls } \\
\text { shall be incorporated in the design and engineering of low- } \\
\text { level waste treatment and storage facilities to provide volume } \\
\text { inventory data and to prevent spills, leaks, and overflows } \\
\text { from tanks or confinement systems. }\end{array}$ & See M. above. \\
\hline $\begin{array}{l}\text { (e) Monitoring. Monitoring and/or leak detection capabilities } \\
\text { shall be incorporated in the design and engineering of low- } \\
\text { level waste treatment and storage facilities to provide rapid } \\
\text { identification of failed confinement and/or other abnormal } \\
\text { conditions. }\end{array}$ & See M. above. \\
\hline $\begin{array}{l}\text { (3) Low-Level Waste Disposal Facility Design. The following } \\
\text { facility requirements and general design criteria, at a minimum, } \\
\text { apply: }\end{array}$ & See M. above. \\
\hline $\begin{array}{l}\text { (a) Confinement. Low-level waste systems and components shall } \\
\text { be designed to maintain waste confinement. }\end{array}$ & See M. above. \\
\hline (b) Ventilation. & See M. above. \\
\hline $\begin{array}{l}1 \text { Design of low-level waste disposal facilities shall include } \\
\text { ventilation, if applicable, through an appropriate filtration } \\
\text { system to maintain the release of radioactive material in } \\
\text { airborne effluents within the requirements and guidelines } \\
\text { specified in applicable requirements. }\end{array}$ & See M. above. \\
\hline $\begin{array}{l}2 \text { When conditions exist for generating gases in flammable or } \\
\text { explosive concentrations, ventilation systems or other } \\
\text { measures shall be provided to keep the gases in a non- }\end{array}$ & See M. above. \\
\hline
\end{tabular}


Table 3. (continued).

\begin{tabular}{|c|c|}
\hline \multicolumn{2}{|c|}{ Facility Name: CPP-1634, Technology Development Facility } \\
\hline Chapter IV, LLW Requirements & Facility Compliance Information \\
\hline $\begin{array}{l}\text { flammable and non-explosive condition. Where } \\
\text { concentrations of explosive or flammable gases are } \\
\text { expected to approach the lower flammability limit, } \\
\text { measures shall be taken to prevent deflagration or } \\
\text { detonation. }\end{array}$ & \\
\hline $\begin{array}{l}\text { (c) Stability. Low-level waste disposal facilities shall be designed } \\
\text { to achieve long-term stability and to minimize to the extent } \\
\text { practical, the need for active maintenance following final } \\
\text { closure. }\end{array}$ & See M. above. \\
\hline $\begin{array}{l}\text { (d) Control of Water. Low-level waste disposal facilities shall be } \\
\text { designed to minimize to the extent practical, the contact of } \\
\text { waste with water during and after disposal. }\end{array}$ & See M. above. \\
\hline $\begin{array}{l}\text { N. Storage and Staging. The following requirements are in addition to } \\
\text { those in Chapter I of this Manual [DOE M 435.1-1 §I.2.F(13)]. }\end{array}$ & $\begin{array}{l}\text { DOE Manual 435.1-1 §I.2.F(13) applies to } \\
\text { field element managers. }\end{array}$ \\
\hline $\begin{array}{l}\text { (1) Storage Prohibitions. Low-level waste in storage shall not be } \\
\text { readily capable of detonation, explosive decomposition, reaction } \\
\text { at anticipated pressures and temperatures, or explosive reaction } \\
\text { with water. Prior to storage, pyrophoric materials shall be treated, } \\
\text { prepared, and packaged to be nonflammable. } \\
\text { From DOE G 435.1-1 Chapter IV: Compliance with this } \\
\text { requirement is demonstrated by having waste acceptance } \\
\text { requirements which prohibit low-level waste that is ignitable or } \\
\text { explosive from being accepted for storage unless it has been } \\
\text { treated, and procedures for properly preparing such materials for } \\
\text { safe storage. }\end{array}$ & NA; this facility does not store LLW. \\
\hline $\begin{array}{l}\text { (2) Storage Limit. Low-level waste that has an identified path to } \\
\text { disposal shall not be stored longer than one year prior to disposal, } \\
\text { except for storage for decay, or as otherwise authorized by the } \\
\text { Field Element Manager. }\end{array}$ & $\begin{array}{l}\text { NA; this facility does not store LLW. See } \\
\text { N. (7) below for staging requirements. }\end{array}$ \\
\hline $\begin{array}{l}\text { From DOE G } 435.1-1 \text { Chapter IV: Storage longer than one year } \\
\text { can be justified if the conditions for such storage are approved by } \\
\text { the Field Element Manager as part of the radioactive waste } \\
\text { management basis for the facility. }\end{array}$ & \\
\hline $\begin{array}{l}\text { Storage for radioactive decay for a period greater than } 1 \text { year for } \\
\text { waste that has an identified path to disposal is allowed. Adequate } \\
\text { justification and the supporting information for storage for decay } \\
\text { is to be documented in the radioactive waste management basis } \\
\text { for the facility in which the storage will take place. }\end{array}$ & \\
\hline $\begin{array}{l}\text { (a) Mixed waste. Under the Federal Facility Compliance Act of } \\
\text { 1992, DOE sites were required to develop Site Treatment } \\
\text { Plans to bring stored mixed low-level waste into compliance } \\
\text { with these requirements. The Site Treatment Plan needs to be } \\
\text { consulted and any mixed low-level waste stored for the } \\
\text { purpose of accumulation to facilitate treatment must meet } \\
\text { Resource Conservation and Recovery Act storage } \\
\text { requirements. There could be several ways within different } \\
\text { scenarios that this requirement can be met, as illustrated by } \\
\text { the examples below, however, there are basically four ways to } \\
\text { show compliance with the requirement and include }\end{array}$ & \\
\hline
\end{tabular}


Table 3. (continued).

Facility Name: CPP-1634, Technology Development Facility

Chapter IV, LLW Requirements

Facility Compliance Information

appropriate provisions in the radioactive waste management basis for the facility in which it is stored.

(b) Legacy waste. As discussed above, the intention of the requirement is not to force malicious compliance or heroic actions which would result in increased risk or safety concerns. Rather, the intention is that waste in storage longer than one year receives additional attention to ensure that the public, the workers, and the environment are protected from the hazards of the waste, and that progress is being made to dispose of the waste. There could be several ways within different scenarios that this requirement can be met, as illustrated by the examples below, however, there are basically four ways to show compliance with the requirement:

1 the radioactive waste management basis allows for storage for no more than one year.

2 the radioactive waste management basis allows for storage for no more than one year, or for storage for decay only for periods greater than a year, which are specified on a radionuclide basis.

3 the radioactive waste management basis allows for storage for more than one year, up to a specified period of time based on a documented technical evaluation that the waste can be stored in a manner that does not cause changes to the waste or waste packages that is detrimental to the safe storage of the waste, the final disposal of the waste or to meeting the disposal performance objectives.

4 the radioactive waste management basis allows for storage for decay (with specifics) and for storage for more than one year for other low-level waste, up to a specified period of time based on a documented technical evaluation that the waste can be stored in a manner that does not cause changes to the waste or waste packages that is detrimental to the safe storage of the waste, the final disposal of the waste or to meeting the disposal performance objectives.

Compliance with this requirement is demonstrated by the existence of a radioactive waste management basis for the storage facility approved by the Field Element Manager that includes the time frames that waste are allowed to be stored, the necessary justifications for storage for decay, and the necessary technical evaluations if storage is to extend significantly beyond the one-year time frame.

(3) Storage Integrity. Low-level waste shall be stored in a location and manner that protects the integrity of waste for the expected time of storage and minimizes worker exposure.

From DOE G 435.1-1 Chapter IV: However, in making a decision to use a facility for storage and in developing a radioactive waste management basis for the activity, particular attention to protection of workers is needed.

Compliance with this requirement is demonstrated if sites have storage capabilities for low-level waste that provide protection to

NA; this facility does not store LLW. See N. (7) below for staging requirements. 
Table 3. (continued).

\begin{tabular}{|c|c|}
\hline \multicolumn{2}{|c|}{ Facility Name: CPP-1634, Technology Development Facility } \\
\hline Chapter IV, LLW Requirements & Facility Compliance Information \\
\hline $\begin{array}{l}\text { waste containers so that their integrity will not be damaged } \\
\text { through physical or chemical (corrosion) processes and that keep } \\
\text { personnel from spending extended periods of time in the areas } \\
\text { where low-level waste is stored. }\end{array}$ & \\
\hline (4) Waste Characterization for Storage. & $\begin{array}{l}\text { NA; this facility does not store LLW. See } \\
\text { N. (7) below for staging requirements. }\end{array}$ \\
\hline $\begin{array}{l}\text { (a) Low-level waste that does not have an identified path to } \\
\text { disposal shall be characterized as necessary to meet the data } \\
\text { quality objectives and minimum characterization } \\
\text { requirements of this Chapter, to ensure safe storage, and to } \\
\text { facilitate disposal. }\end{array}$ & $\begin{array}{l}\text { NA; this facility does not store LLW. See } \\
\text { N. (7) below for staging requirements. }\end{array}$ \\
\hline $\begin{array}{l}\text { (b) Characterization information for all low-level waste in } \\
\text { storage shall be maintained as a record in accordance with the } \\
\text { requirements for Records Management in Chapter I of this } \\
\text { Manual. } \\
\text { From DOE G 435.1-1 Chapter IV: Compliance with this } \\
\text { requirement is demonstrated by documented procedures for } \\
\text { managing waste characterization and container information } \\
\text { on low-level waste as a Federal record. The records are } \\
\text { managed per the applicable policies and procedures for } \\
\text { records management referenced in DOE O } 200.1 \text { and } \\
\text { established at the applicable Field Element. }\end{array}$ & $\begin{array}{l}\text { NA; this facility does not store LLW. See } \\
\text { N. (7) below for staging requirements. }\end{array}$ \\
\hline $\begin{array}{l}\text { (5) Container Inspection. A process shall be developed and } \\
\text { implemented for inspecting and maintaining containers of low- } \\
\text { level waste to ensure container integrity is not compromised. } \\
\text { From DOE G 435.1-1 Chapter IV: Compliance with this } \\
\text { requirement is demonstrated by: (1) a documented process for } \\
\text { waste container inspection and maintenance; and (2) } \\
\text { documentation for all waste container inspections and } \\
\text { maintenance actions performed. }\end{array}$ & $\begin{array}{l}\text { LI- } 435 \text { requires quarterly inspections of } \\
\text { radioactive waste containers if waste is } \\
\text { stored outdoors or has been in storage for } \\
\text { greater than } 1 \text { year. }\end{array}$ \\
\hline $\begin{array}{l}\text { (6) Storage Management. Low-level waste storage shall be managed } \\
\text { to identify and segregate low-level waste from mixed low-level } \\
\text { waste. }\end{array}$ & $\begin{array}{l}\text { NA; this facility does not store LLW. See } \\
\text { N. (7) below for staging requirements. }\end{array}$ \\
\hline $\begin{array}{l}\text { (7) Staging. Staging of low-level waste shall be for the purpose of } \\
\text { the accumulation of such quantities of waste as necessary to } \\
\text { facilitate transportation, treatment, and disposal. Staging longer } \\
\text { than } 90 \text { days shall meet the requirements for storage above and in } \\
\text { Chapter I of this Manual. } \\
\text { From DOE G 435.1-1 Chapter IV: The staging of low-level } \\
\text { waste needs to be addressed in the radioactive waste management } \\
\text { basis for the facility that is performing the staging. Generators, } \\
\text { treatment facilities, and disposal facilities that stage waste must } \\
\text { ensure that the action of staging is included and authorized as } \\
\text { part of their radioactive waste management basis for the affected } \\
\text { facilities, operations, or activities. } \\
\text { Staging longer than } 90 \text { days must be justified, the conditions for } \\
\text { such storage met, and these practices approved by the Field } \\
\text { Element Manager as part of the radioactive waste management } \\
\text { basis for the facility. }\end{array}$ & $\begin{array}{l}\text { Routine LLW, such as personal protective } \\
\text { equipment, is accumulated at this facility } \\
\text { for disposal. MCP-17000, Appendix F, } \\
\text { "Container Start Date and Storage } \\
\text { Prohibitions," restricts staging LLW to a } \\
90 \text {-day maximum at any generator or } \\
\text { treatment facility prior to acceptance by a } \\
\text { storage facility. } \\
\text { As stated in DOE Guide } 435.1-1 \\
\text { \$V.N.( }(7) \text {, staging waste in accordance } \\
\text { with this requirement allows waste to be } \\
\text { accumulated without being considered } \\
\text { storage and being bound by the associated } \\
\text { storage requirements. }\end{array}$ \\
\hline
\end{tabular}


Table 3. (continued).

\begin{tabular}{|c|c|}
\hline \multicolumn{2}{|c|}{ Facility Name: CPP-1634, Technology Development Facility } \\
\hline Chapter IV, LLW Requirements & Facility Compliance Information \\
\hline $\begin{array}{l}\text { Compliance with this requirement is demonstrated by a staging } \\
\text { program that limits the temporary storage of waste to only } \\
\text { circumstances allowed in the requirement, including } \\
\text { justifications for any staging that exceeds the } 90 \text {-day period, } \\
\text { which is documented in the radioactive waste management basis } \\
\text { for the facility. }\end{array}$ & \\
\hline $\begin{array}{l}\text { O. Treatment. Low-level waste treatment to provide more stable waste } \\
\text { forms and to improve the long-term performance of a low-level } \\
\text { waste disposal facility shall be implemented as necessary to meet the } \\
\text { performance objectives of the disposal facility. }\end{array}$ & NA; this facility does not treat LLW. \\
\hline $\begin{array}{l}\text { From DOE G 435.1-1 Chapter IV: Compliance with this requirement } \\
\text { is demonstrated when a treatment facility or process ensures that } \\
\text { treated waste will meet the minimum waste form requirements of } \\
\text { DOE M } 435.1 \text { and meet additional disposal facility-specific waste } \\
\text { acceptance requirements for additional stability or long-term } \\
\text { performance of facilities that will receive the treated waste. }\end{array}$ & \\
\hline $\begin{array}{l}\text { P. Disposal. Low-level waste disposal facilities shall meet the } \\
\text { following requirements. }\end{array}$ & NA; this facility does not dispose of LLW \\
\hline $\begin{array}{l}\text { (1) Performance Objectives. Low-level waste disposal facilities shall } \\
\text { be sited, designed, operated, maintained, and closed so that a } \\
\text { reasonable expectation exists that the following performance } \\
\text { objectives will be met for waste disposed of after September 26, } \\
\text { 1988: }\end{array}$ & See P. above. \\
\hline $\begin{array}{l}\text { (a) Dose to representative members of the public shall not exceed } \\
25 \mathrm{mrem}(0.25 \mathrm{mSv}) \text { in a year total effective dose equivalent } \\
\text { from all exposure pathways, excluding the dose from radon } \\
\text { and its progeny in air. }\end{array}$ & See P. above. \\
\hline $\begin{array}{l}\text { (b) Dose to representative members of the public via the air } \\
\text { pathway shall not exceed } 10 \text { mrem }(0.10 \mathrm{mSv}) \text { in a year total } \\
\text { effective dose equivalent, excluding the dose from radon and } \\
\text { its progeny. }\end{array}$ & See P. above. \\
\hline $\begin{array}{l}\text { (c) Release of radon shall be less than an average flux of } 20 \\
\mathrm{pCi} / \mathrm{m}^{2} / \mathrm{s}\left(0.74 \mathrm{~Bq} / \mathrm{m}^{2} / \mathrm{s}\right) \text { at the surface of the disposal facility. } \\
\text { Alternatively, a limit of } 0.5 \mathrm{pCi} / 1(0.0185 \mathrm{~Bq} / \mathrm{l}) \text { of air may be } \\
\text { applied at the boundary of the facility. }\end{array}$ & See P. above. \\
\hline $\begin{array}{l}\text { (2) Performance Assessment. A site-specific radiological } \\
\text { performance assessment shall be prepared and maintained for } \\
\text { DOE low-level waste disposed of after September } 26,1988 \text {. The } \\
\text { performance assessment shall include calculations for a } 1,000 \\
\text { year period after closure of potential doses to representative } \\
\text { future members of the public and potential releases from the } \\
\text { facility to provide a reasonable expectation that the performance } \\
\text { objectives identified in this Chapter are not exceeded as a result } \\
\text { of operation and closure of the facility. }\end{array}$ & See P. above. \\
\hline $\begin{array}{l}\text { (a) Analyses performed to demonstrate compliance with the } \\
\text { performance objectives in this Chapter, and to establish limits } \\
\text { on concentrations of radionuclides for disposal based on the } \\
\text { performance measures for inadvertent intruders in this } \\
\text { Chapter shall be based on reasonable activities in the critical }\end{array}$ & See P. above. \\
\hline
\end{tabular}


Table 3. (continued).

\begin{tabular}{|c|c|}
\hline \multicolumn{2}{|c|}{ Facility Name: CPP-1634, Technology Development Facility } \\
\hline Chapter IV, LLW Requirements & Facility Compliance Information \\
\hline $\begin{array}{l}\text { group of exposed individuals. Unless otherwise specified, the } \\
\text { assumption of average living habits and exposure conditions } \\
\text { in representative critical groups of individuals projected to } \\
\text { receive the highest doses is appropriate. The likelihood of } \\
\text { inadvertent intruder scenarios may be considered in } \\
\text { interpreting the results of the analyses and establishing } \\
\text { radionuclide concentrations, if adequate justification is } \\
\text { provided. }\end{array}$ & \\
\hline $\begin{array}{l}\text { (b) The point of compliance shall correspond to the point of } \\
\text { highest projected dose or concentration beyond a } 100 \text { meter } \\
\text { buffer zone surrounding the disposed waste. A larger or } \\
\text { smaller buffer zone may be used if adequate justification is } \\
\text { provided. }\end{array}$ & See P. above. \\
\hline $\begin{array}{l}\text { (c) Performance assessments shall address reasonably foreseeable } \\
\text { natural processes that might disrupt barriers against release } \\
\text { and transport of radioactive materials. }\end{array}$ & See P. above. \\
\hline $\begin{array}{l}\text { (d) Performance assessments shall use DOE-approved dose } \\
\text { coefficients (dose conversion factors) for internal and external } \\
\text { exposure of reference adults. }\end{array}$ & See P. above. \\
\hline $\begin{array}{l}\text { (e) The performance assessment shall include a } \\
\text { sensitivity/uncertainty analysis. }\end{array}$ & See P. above. \\
\hline $\begin{array}{l}\text { (f) Performance assessments shall include a demonstration that } \\
\text { projected releases of radionuclides to the environment shall } \\
\text { be maintained as low as reasonably achievable (ALARA). }\end{array}$ & See P. above. \\
\hline $\begin{array}{l}\text { (g) For purposes of establishing limits on radionuclides that may } \\
\text { be disposed of near-surface, the performance assessment shall } \\
\text { include an assessment of impacts to water resources. }\end{array}$ & See P. above. \\
\hline $\begin{array}{l}\text { (h) For purposes of establishing limits on the concentration of } \\
\text { radionuclides that may be disposed of near-surface, the } \\
\text { performance assessment shall include an assessment of } \\
\text { impacts calculated for a hypothetical person assumed to } \\
\text { inadvertently intrude for a temporary period into the low-level } \\
\text { waste disposal facility. For intruder analyses, institutional } \\
\text { controls shall be assumed to be effective in deterring intrusion } \\
\text { for at least } 100 \text { years following closure. The intruder analyses } \\
\text { shall use performance measures for chronic and acute } \\
\text { exposure scenarios, respectively, of } 100 \text { mrem }(1 \mathrm{mSv}) \text { in a } \\
\text { year and } 500 \text { mrem }(5 \mathrm{mSv}) \text { total effective dose equivalent } \\
\text { excluding radon in air. }\end{array}$ & See P. above. \\
\hline $\begin{array}{l}\text { (3) Composite Analysis. For disposal facilities which received waste } \\
\text { after September 26, 1988, a site-specific radiological composite } \\
\text { analysis shall be prepared and maintained that accounts for all } \\
\text { sources of radioactive material that may be left at the DOE site } \\
\text { and may interact with the low- level waste disposal facility, } \\
\text { contributing to the dose projected to a hypothetical member of } \\
\text { the public from the existing or future disposal facilities. } \\
\text { Performance measures shall be consistent with DOE } \\
\text { requirements for protection of the public and environment and } \\
\text { evaluated for a 1,000 year period following disposal facility } \\
\text { closure. The composite analysis results shall be used for }\end{array}$ & See P. above. \\
\hline
\end{tabular}


Table 3. (continued).

\begin{tabular}{|c|c|}
\hline \multicolumn{2}{|c|}{ Facility Name: CPP-1634, Technology Development Facility } \\
\hline Chapter IV, LLW Requirements & Facility Compliance Information \\
\hline $\begin{array}{l}\text { planning, radiation protection activities, and future use } \\
\text { commitments to minimize the likelihood that current low- level } \\
\text { waste disposal activities will result in the need for future } \\
\text { corrective or remedial actions to adequately protect the public } \\
\text { and the environment. }\end{array}$ & \\
\hline $\begin{array}{l}\text { (4) Performance Assessment and Composite Analysis Maintenance. } \\
\text { The performance assessment and composite analysis shall be } \\
\text { maintained to evaluate changes that could affect the performance, } \\
\text { design, and operating bases for the facility. Performance } \\
\text { assessment and composite analysis maintenance shall include the } \\
\text { conduct of research, field studies, and monitoring needed to } \\
\text { address uncertainties or gaps in existing data. The performance } \\
\text { assessment shall be updated to support the final facility closure. } \\
\text { Additional iterations of the performance assessment and } \\
\text { composite analysis shall be conducted as necessary during the } \\
\text { post-closure period. }\end{array}$ & See P. above. \\
\hline $\begin{array}{l}\text { (a) Performance assessments and composite analyses shall be } \\
\text { reviewed and revised when changes in waste forms or } \\
\text { containers, radionuclide inventories, facility design and } \\
\text { operations, closure concepts, or the improved understanding } \\
\text { of the performance of the waste disposal facility in } \\
\text { combination with the features of the site on which it is located } \\
\text { alter the conclusions or the conceptual model(s) of the } \\
\text { existing performance assessment or composite analysis. }\end{array}$ & See P. above. \\
\hline $\begin{array}{l}\text { (b) A determination of the continued adequacy of the } \\
\text { performance assessment and composite analysis shall be } \\
\text { made on an annual basis, and shall consider the results of data } \\
\text { collection and analysis from research, field studies, and } \\
\text { monitoring. }\end{array}$ & See P. above. \\
\hline $\begin{array}{l}\text { (c) Annual summaries of low-level waste disposal operations } \\
\text { shall be prepared with respect to the conclusions and } \\
\text { recommendations of the performance assessment and } \\
\text { composite analysis and a determination of the need to revise } \\
\text { the performance assessment or composite analysis. }\end{array}$ & See P. above. \\
\hline $\begin{array}{l}\text { (5) Disposal Authorization. A disposal authorization statement shall } \\
\text { be obtained prior to construction of a new low-level waste } \\
\text { disposal facility. Field Elements with existing low-level waste } \\
\text { disposal facilities shall obtain a disposal authorization statement } \\
\text { in accordance with the schedule in the Complex-Wide Low- } \\
\text { Level Waste Management Program Plan. The disposal } \\
\text { authorization statement shall be issued based on a review of the } \\
\text { facility's performance assessment, composite analysis, } \\
\text { performance assessment and composite analysis maintenance, } \\
\text { preliminary closure plan, and preliminary monitoring plan. The } \\
\text { disposal authorization statement shall specify the limits and } \\
\text { conditions on construction, design, operations, and closure of the } \\
\text { low-level waste facility based on these reviews. A disposal } \\
\text { authorization statement is a part of the radioactive waste } \\
\text { management basis for a disposal facility. Failure to obtain a } \\
\text { disposal authorization statement by the implementation date of } \\
\text { this Order shall result in shutdown of the disposal facility. }\end{array}$ & See P. above. \\
\hline
\end{tabular}


Table 3. (continued).

\begin{tabular}{|c|c|}
\hline \multicolumn{2}{|c|}{ Facility Name: CPP-1634, Technology Development Facility } \\
\hline Chapter IV, LLW Requirements & Facility Compliance Information \\
\hline $\begin{array}{l}\text { (6) Disposal Facility Operations. The disposal facility design and } \\
\text { operation must be consistent with the disposal facility closure } \\
\text { plan and lead to disposal facility closure that provides a } \\
\text { reasonable expectation that performance objectives will be met. } \\
\text { Low-level waste shall be disposed in such a manner that achieves } \\
\text { the performance objectives stated in this Chapter, consistent with } \\
\text { the disposal facility radiological performance assessment. } \\
\text { Additional requirements include: }\end{array}$ & $\begin{array}{l}\text { See P. above. } \\
\end{array}$ \\
\hline $\begin{array}{l}\text { (a) Operating procedures shall be developed and implemented for } \\
\text { low-level waste disposal facilities that protect the public, } \\
\text { workers, and the environment; ensure the security of the } \\
\text { facility; minimize subsidence during and after waste } \\
\text { emplacement; achieve long-term stability and minimize the } \\
\text { need for long-term active maintenance; and meet the } \\
\text { requirements of the closure/post-closure plan. }\end{array}$ & See P. above. \\
\hline $\begin{array}{l}\text { (b) Permanent identification markers for disposal excavations } \\
\text { and monitoring wells shall be emplaced. }\end{array}$ & See P. above. \\
\hline $\begin{array}{l}\text { (c) Low-level waste placement into disposal units shall minimize } \\
\text { voids between waste containers. Voids within disposal units } \\
\text { shall be filled to the extent practical. Uncontainerized bulk } \\
\text { waste shall also be placed in a manner that minimizes voids } \\
\text { and subsidence. }\end{array}$ & See P. above. \\
\hline $\begin{array}{l}\text { (d) Operations are to be conducted so that active waste disposal } \\
\text { operations will not have an adverse effect on any other } \\
\text { disposal units. }\end{array}$ & See P. above. \\
\hline $\begin{array}{l}\text { (e) Operations shall include a process for tracking and } \\
\text { documenting low-level waste placement in the facility by } \\
\text { generator source. }\end{array}$ & See P. above. \\
\hline $\begin{array}{l}\text { (7) Alternate Requirements for Low-Level Waste Disposal Facility } \\
\text { Design and Operation. Requirements other than those set forth in } \\
\text { this Section for the design and operation of a low-level waste } \\
\text { disposal facility may be approved on a specific basis if a } \\
\text { reasonable expectation is demonstrated that the disposal } \\
\text { performance objectives will be met. }\end{array}$ & See P. above. \\
\hline $\begin{array}{l}\text { Q. Closure. The following requirements are in addition to those in } \\
\text { Chapter I of this Manual. }\end{array}$ & NA; this facility does not dispose of LLW \\
\hline $\begin{array}{l}\text { (1) Disposal Facility Closure Plans. A preliminary closure plan shall } \\
\text { be developed and submitted to Headquarters for review with the } \\
\text { performance assessment and composite analysis. The closure } \\
\text { plan shall be updated following issuance of the disposal } \\
\text { authorization statement to incorporate conditions specified in the } \\
\text { disposal authorization statement. Closure plans shall: }\end{array}$ & See Q. above. \\
\hline $\begin{array}{l}\text { (a) Be updated as required during the operational life of the } \\
\text { facility. }\end{array}$ & See Q. above. \\
\hline $\begin{array}{l}\text { (b) Include a description of how the disposal facility will be } \\
\text { closed to achieve long-term stability and minimize the need } \\
\text { for active maintenance following closure and to ensure } \\
\text { compliance with the requirements of DOE 5400.5, Radiation } \\
\text { Protection of the Public and the Environment. }\end{array}$ & See Q. above. \\
\hline
\end{tabular}


Table 3. (continued).

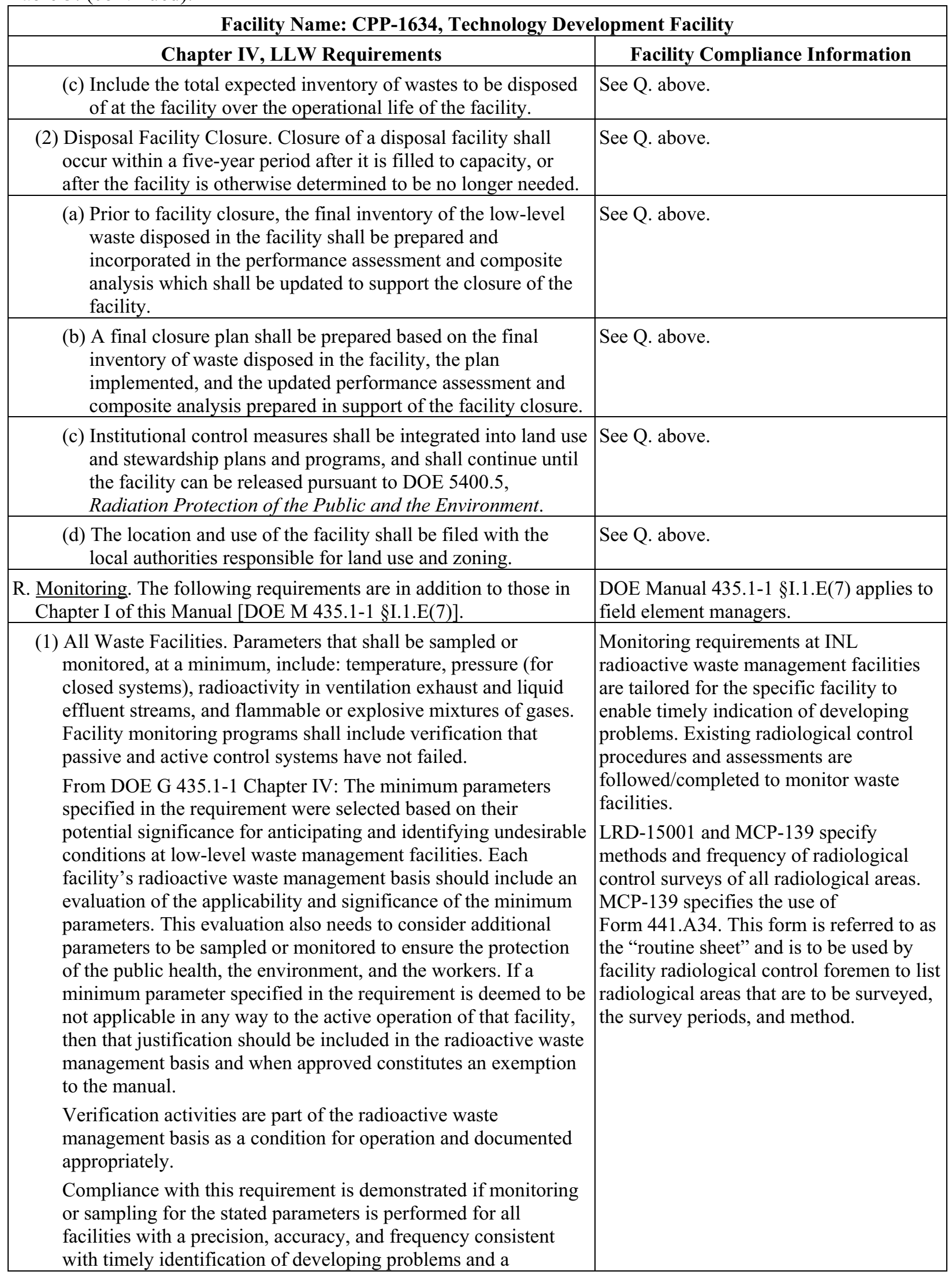


Table 3. (continued).

\begin{tabular}{|c|c|}
\hline \multicolumn{2}{|c|}{ Facility Name: CPP-1634, Technology Development Facility } \\
\hline Chapter IV, LLW Requirements & Facility Compliance Information \\
\hline $\begin{array}{l}\text { justification exists in the approved radioactive waste } \\
\text { management basis for those specified parameters which are not } \\
\text { monitored or sampled. }\end{array}$ & \\
\hline $\begin{array}{l}\text { (2) Liquid Waste Storage Facilities. For facilities storing liquid low- } \\
\text { level waste, the following shall also be monitored: liquid level } \\
\text { and/or waste volume, and significant waste chemistry } \\
\text { parameters. }\end{array}$ & $\begin{array}{l}\text { NA; liquid LLW is not stored in this } \\
\text { facility. }\end{array}$ \\
\hline $\begin{array}{l}\text { (3) Disposal Facilities. A preliminary monitoring plan for a low- } \\
\text { level waste disposal facility shall be prepared and submitted to } \\
\text { Headquarters for review with the performance assessment and } \\
\text { composite analysis. The monitoring plan shall be updated within } \\
\text { one year following issuance of the disposal authorization } \\
\text { statement to incorporate and implement conditions specified in } \\
\text { the disposal authorization statement. }\end{array}$ & NA; this facility does not dispose of LLW \\
\hline $\begin{array}{l}\text { (a) The site-specific performance assessment and composite } \\
\text { analysis shall be used to determine the media, locations, } \\
\text { radionuclides, and other substances to be monitored. }\end{array}$ & See (3) above. \\
\hline $\begin{array}{l}\text { (b) The environmental monitoring program shall be designed to } \\
\text { include measuring and evaluating releases, migration of } \\
\text { radionuclides, disposal unit subsidence, and changes in } \\
\text { disposal facility and disposal site parameters which may } \\
\text { affect long-term performance. }\end{array}$ & See (3) above. \\
\hline $\begin{array}{l}\text { (c) The environmental monitoring programs shall be capable of } \\
\text { detecting changing trends in performance to allow application } \\
\text { of any necessary corrective action prior to exceeding the } \\
\text { performance objectives in this Chapter. }\end{array}$ & See (3) above. \\
\hline
\end{tabular}

\section{REFERENCES}

DOE Guide 435.1-1, "Implementation Guide for Use with DOE M 435.1-1," U.S. Department of Energy, July 1999.

DOE Manual 435.1-1, "Radioactive Waste Management Manual,” U.S. Department of Energy, July 1999.

DOE Order 435.1, “Radioactive Waste Management,” U.S. Department of Energy, July 1999.

ECAR-999, "Hazard Categorization for CPP-1634 at the Material Security and Consolidation Complex," Idaho National Laboratory.

ECAR-1000, "Hazard Categorization for CPP-653 at the Material Security and Consolidation Complex," Idaho National Laboratory.

Form 435.39, "Waste Determination and Disposition Form (WDDF)," Idaho National Laboratory.

Form 435.42, "Radioactive Waste Inventory Sheet," Idaho National Laboratory.

Form 441.A34, "INL Radiological Control Required Surveys," Idaho National Laboratory

IAG-514, "INL Authorization Agreement for Understanding Between Battelle Energy Alliance (BEA) and CH2M-WGI (CWI) for the Turnover and Operation of CPP-609, CPP-651, CPP-653, CPP-661, CPP-1634, and CPP-1674," Idaho National Laboratory.

LI-419, "RDD Decontamination Tests,” Idaho National Laboratory. 
LI-435, “Waste Management Routine Field Activities," Idaho National Laboratory.

LI 1643-11-INTEC, “General Powder Processing,” Idaho National Laboratory.

LRD-15001, "Radiological Control Manual,” Idaho National Laboratory

LWP-8000, "Environmental Instructions for Facilities, Processes, Materials and Equipment," Idaho National Laboratory.

LWP-13840, "Management of Issues, Observations, and Noteworthy Practices,” Idaho National Laboratory.

LWP-14002, “Timeout and Stop Work Authority,” Idaho National Laboratory

LWP-15011, "Radioactive Material Areas and Radioactive Storage Areas,” Idaho National Laboratory.

LWP-17000, "Waste Management," Idaho National Laboratory.

MCP-139, "Radiological Surveys," Idaho National Laboratory

MCP-17000, “Waste Generator Services Waste Management,” Idaho National Laboratory.

MCP-17500, "Waste Generator Services Certification of Waste Shipments to the Nevada Test Site," Idaho National Laboratory.

PDD-17000, “Waste Management Program,” Idaho National Laboratory.

PLN-114, “INL Emergency Plan/RCRA Contingency Plan,” Idaho National Laboratory.

PLN-522, "Quality Assurance Program Plan for the Waste Management/Waste Certification Program," Idaho National Laboratory.

PLN-3941, "Materials and Security Consolidation Complex Radioactive Waste Management Basis," Idaho National Laboratory.

SAR-115, "Safety Analysis Report for the Unirradiated Fuel Storage Facility." Note: SAR/TSR-416 will replace SAR-115 beginning October 1, 2012. 